\title{
DISCLAIMER
}

This report was prepared as an acount of work uponsored by an ayency of the United Stutes Gowenment. Neither the United States Government nor any sency theteof, nor any of their employees, makes any wartanty, express or implied, or asumes any legal liability or responibility for the accuracy, completenew, or unefulnua of any information, apparatus, product, or proceen diecloed, or represents that its use would not infringe privately owned rights. Reference herein to any epecific commercial product, proceat, or service by trade name, trademark, aenufectuier, or otherwive dow not necewarily conslitute or imply its endoriement, recommedation, or favorias by the United Statew Government or any asency thereof. The views and opiniom of authors exprened herein do not necenarily state or reflect those of the United Stutes Government or any aeency thereof.

\section{Critical Review of the Chemistry and Thermodynamics of Technetium and Some of its Inorganic Compounds and Aqueous Species}

\author{
J. A. $\operatorname{Rard}^{*}$
}

Manuscript date: September.15, 1983

* Earth Sciences Division

\section{LAWRENCE LIVERMORE NATIONAL LABORATORY University of California - Livermore, California - 94550}

Available from: National Technical information Service $\bullet$ U.S. Department of Commerce 528\$ Port Royal Road - Springfield, VA $22161 \bullet \$ 11.50$ per copy $\bullet$ (Microliche \$ $\$ .50$ ) 
Abstract $\quad . \ldots \ldots \ldots \ldots \ldots \ldots \ldots \ldots \ldots \ldots \ldots \ldots \ldots \ldots \ldots \ldots \ldots \ldots \ldots \ldots \ldots \ldots \ldots \ldots \ldots \ldots \ldots \ldots \ldots \ldots \ldots . . \ldots$ v

Introduction $\ldots \ldots \ldots \ldots \ldots \ldots \ldots \ldots \ldots \ldots \ldots \ldots \ldots \ldots \ldots \ldots \ldots \ldots \ldots \ldots \ldots \ldots \ldots \ldots \ldots \ldots \ldots \ldots$

Analysis of Chemical and Thermodynamic Data .................... 3

Data for Solids, Liquids, and Gases ..................... 3

Elementel Technetium .............................. 3

Ketallic Alloys and Hydrides $\ldots \ldots \ldots \ldots \ldots \ldots \ldots \ldots \ldots \ldots \ldots \ldots \ldots . . . \ldots$

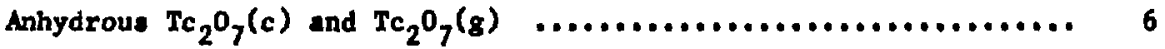

Anhydrous $\mathrm{TcO}_{2}(\mathrm{c})$ and $\mathrm{TcO}_{3}(\mathrm{c}) \quad \ldots \ldots \ldots \ldots \ldots \ldots \ldots \ldots \ldots \ldots \ldots \ldots$

Anhydrous Solid Ternary oxides $\quad \ldots \ldots \ldots \ldots \ldots \ldots \ldots \ldots \ldots \ldots \ldots \ldots \ldots \ldots \ldots . . \ldots$

Hydrated $\mathrm{TcO}_{2}(\mathrm{am}) \quad \ldots \ldots \ldots \ldots \ldots \ldots \ldots \ldots \ldots \ldots \ldots \ldots \ldots \ldots \ldots \ldots \ldots \ldots \ldots \ldots . \ldots$

other Hydrated Oxidea and Hydroxides: TcOH, $\mathrm{Tc}(\mathrm{OH})_{2}$,

$\mathrm{Tc}(\mathrm{OH})_{3}, \mathrm{Tc}_{3} \mathrm{O}_{4}, \mathrm{Tc}_{4} \mathrm{O}_{7}$, and $\mathrm{Tc}_{4} \mathrm{O}_{5} \mathrm{TmH}_{2} \mathrm{O} \ldots \ldots \ldots \ldots \ldots \ldots \ldots \ldots \ldots$

Solid Pertechnetates $\ldots \ldots \ldots \ldots \ldots \ldots \ldots \ldots \ldots \ldots \ldots \ldots \ldots \ldots \ldots \ldots \ldots \ldots \ldots \ldots \ldots$

Solid Tetraoxotechnetates $\left(\mathrm{TcO}_{4}^{2-}\right) \ldots \ldots \ldots \ldots \ldots \ldots \ldots \ldots \ldots \ldots \ldots \ldots \ldots$

Anhydrous Technetiun Halides $\ldots \ldots \ldots \ldots \ldots \ldots \ldots \ldots \ldots \ldots \ldots \ldots \ldots \ldots \ldots . \ldots . \ldots 16$

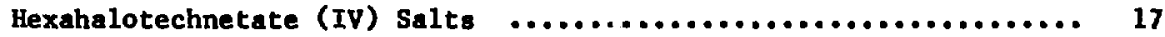

Other Halotechnetate Salts $\ldots \ldots \ldots \ldots \ldots \ldots \ldots \ldots \ldots \ldots \ldots \ldots \ldots \ldots \ldots \ldots \ldots \ldots . \ldots 18$

Solid Octahaloditechnetate Salts $\ldots \ldots \ldots \ldots \ldots \ldots \ldots \ldots \ldots \ldots \ldots \ldots \ldots \ldots \ldots \ldots .18$

Anhydrous Oxyhalides .................................... 19

Solid Tc(v) 0xyhalide Salts $\ldots \ldots \ldots \ldots \ldots \ldots \ldots \ldots \ldots \ldots \ldots \ldots \ldots \ldots \ldots \ldots \ldots \ldots . \ldots 20$

Solid Tc(IV) and Tc(VI) Oxyhalide Salts $\ldots \ldots \ldots \ldots \ldots \ldots \ldots \ldots \ldots \ldots \ldots \ldots . \ldots 21$

Technetium Sulfides, Nitrides, Borides, and Carbides .......... 22

Comants on Thermodynamic Stability and the Effects of Radiation... 23

Data for Aqueous Solutions ................................ 24

General Comments .................................... 24

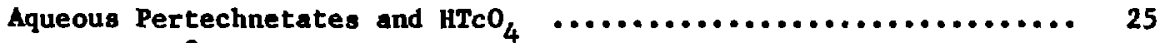

Aqueous $\mathrm{TcO}_{4}^{2-}, \mathrm{HTCO}_{4}^{-}$, and $\mathrm{H}_{2} \mathrm{TcO}_{4}, \ldots \ldots \ldots \ldots \ldots \ldots \ldots \ldots \ldots \ldots \ldots \ldots$

Aqueous $\mathrm{TcO}_{4}^{3-}$ and Other Aqueous $\mathrm{Tc}(\mathrm{V})$ Species $\ldots \ldots \ldots \ldots \ldots \ldots \ldots \ldots$

Polarography, Coulowetry, and the Identification of Tc Aqueous

Species $\ldots \ldots \ldots \ldots \ldots \ldots \ldots \ldots \ldots \ldots \ldots \ldots \ldots \ldots \ldots \ldots \ldots \ldots \ldots \ldots \ldots \ldots \ldots \ldots \ldots \ldots \ldots . . \ldots$ 
Aqueous $\mathrm{TcO}^{2+}, \mathrm{TcO}(\mathrm{OH})^{+}, \mathrm{TcO}(\mathrm{OH})_{2}^{\circ},\left[\mathrm{TcO}(\mathrm{OH})_{2}^{\circ}\right]_{2}$,

Colloidal $\mathrm{TcO}_{2}$, and other Tc(IV) species

Aqueous $\mathrm{Tc}^{3+}$, $\mathrm{TcO}^{+}, \mathrm{Tc}^{2+}$, and other Lower Valence Tc Species ..... 47

Reduction of $\mathrm{TcO}_{4}^{-}$by Aqueous Hydrohalic Acids, and the

Hydrolysia of $\operatorname{TcCl}_{6}^{2-}$ and $\operatorname{TcBr}_{6}^{2-}$ Ions $\ldots \ldots \ldots \ldots \ldots \ldots \ldots \ldots \ldots$

Thermodynamic Data for Aqueoue Technetium Halide and

Hydroxy-Halide Complexes $\quad \ldots \ldots \ldots \ldots \ldots \ldots \ldots \ldots \ldots \ldots \ldots \ldots \ldots \ldots \ldots \ldots \ldots . \ldots 64$

Aqueous Sulfate, Carbonate, Phosphate, Pyrophosphate, and

Tripolyphosphate Conplexes $\ldots \ldots \ldots \ldots \ldots \ldots \ldots \ldots \ldots \ldots \ldots \ldots \ldots \ldots \ldots \ldots 6 \ldots$

Brief Sumary and Recomendations for Future Studies .............. 67

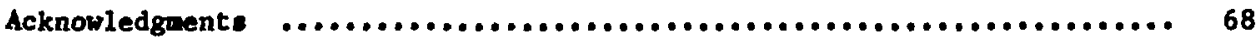

References $\ldots \ldots \ldots \ldots \ldots \ldots \ldots \ldots \ldots \ldots \ldots \ldots \ldots \ldots \ldots \ldots \ldots \ldots \ldots \ldots \ldots \ldots \ldots \ldots \ldots \ldots \ldots \ldots \ldots \ldots . . . \ldots 9$

\section{LIST OF TABLES}

Table

1 Recommended data for elemental Tc. ................... 5

2 Recomended data for oxides and hydroxides at $298 \mathrm{~K}$. ........ 12

3 Recomended data for anhydrous pertechnetates, halides, oxyhalides, and sulfides at $298 \mathrm{k} . \ldots \ldots \ldots \ldots \ldots \ldots \ldots \ldots \ldots \ldots . \ldots 22$

4 Two electron reduction potentials of $\mathrm{TcO}_{4}^{-}$to $\mathrm{TcO}_{4}^{3-}$. $\ldots \ldots \ldots \ldots$

5 Thermodynamic data for aqueous Tc species at $298 \mathrm{~K}$. ........ 57

6 Standard aqueous reduction potentials for Tc. ............. 58 


\title{
Critical Review of the Chemistry and Thermodynamics of Technetium and Some of its Inorganic Compounds and Aqueous Species
}

\begin{abstract}
Chemical and thermodynamic data for Technetium (Tc) and some of its inorganic compounds and aqueous species are reviewed here. Major emphasis is given to systems with potential geochemical applications, especially the geochemistry of radioactive waste disposal. Compounds considered include oxides, hydroxides, hydrated oxides, halides, oxyhalides, double halides, and sulfides. The aqueous species considered include those in both noncomplexing media (pertechnetates, technetates, aquo-ions, and hydrolyzed cations) and complexing media (halides, sulfates, and phosphates). Thermodynamic values are recommended for specific compounds and aqueous ions when reliable experimental data are available. Where thermodynamic data are inadequate or unavailable, the chemistry is still discussed to provide information about what needs to be measured, and which chemistry needs to be clarified.

A major application of these thermodynamic data will be for chemical equilibrium modeling and for construction of potential-pH diagrams for aqueous solutions. Unfortunately, the present lack of data precludes such calculations for complexing aqueous media. The situation is much better for noncomplexing aqueous media, but the chemistry and thermodynamics of cationic $\mathrm{Tc}(\mathrm{V})$ species and hydrolyzed $\mathrm{Tc}(\mathrm{III})$ species are poorly understood.
\end{abstract}


The existence of element number 43 was predicted by Mendeleev in 1869 and named ekamanganese by him. Various early claims were made for its discovery in natural minerals, and different workers gave it the names ilmenium, davyum, lucium, nipponium, and masurium. All of these claims proved to be in error. All isotopes of element 43 are unstable, and the longest lived isotopes have half-lives of over $10^{6}$ years $\left({ }^{97} \mathrm{Tc}\right.$ and $\left.{ }^{98} \mathrm{Tc}\right)$. The amount of primordial material remaining in the earth's crust is extremely small and has not been detected.

The first conclusive experimental evidence for the artifical production of element 43 was given by Perrier and Segre, ${ }^{1,2}$ using sample of Mo bombarded by deuterons in the University of California (Berkeley) cyclotron. They named the element technetiun (Tc) from the Greek word texuntos meaning artificial. All isotopes of Tc with mass numbers from 90 to 110 have now been prepared, along with several nuclear isomers.

Since then, several isotopes of Tc have been shown to occur in very small amounts in the earth's crust. Its presence in Mo ores and platinum metal group concentrates is generally considered to be of secondary origin, i.e., it is probably formed by the interaction of hard cosmic rays with Mo, Ru, or $\mathrm{Nb}$. Tc also appears in uranium ores from the spontaneous fission of ${ }^{238_{\mathrm{U}}}$. When present, it is in the amount of about $10^{-10} \mathrm{~g} \mathrm{Tc} / \mathrm{kg}$ of ore. Tc is also known to occur in certain types of cooler stars in relatively lirge amounts, suggesting continuous production. Several excellent reviews are available regarding its discovery, isotopes, natural occurrence, and applications. ${ }^{3-8}$ Most Tc is now obtained as ${ }^{99}$ Tc from the thermal neutron fission of ${ }^{235} \mathrm{U}$ with about $6 \%$ yield (also from $T h$ or $P u$ ), and it is available in multigram amounts. This is enough to allow many of its chemical and thermodynamic properties to be investigated. $99 \mathrm{~m}_{\mathrm{Tc}}$ and $95 \mathrm{~m}$ Tc are used extensively in nuclear medicine; one entire issue in 1982 of the International Journal of Applied Radiation and Isotopes was ievoted to these applications. Additional applications of Tc in nuclear medicine are given in clark and Fackler's article. ${ }^{9} \mathrm{TcO}_{4}^{-}$also has applications to the inhibition corrosion of iron. 10

An interesting finding about $99 \mathrm{~m}_{\mathrm{Tc}}$ is that its half-life for decay by internal conversion is slightly sensitive to its chemical environment, owing to variations in the electron density of TC within $0.2 \mathrm{~A}$ of the nucleus. 
The 3p and 3d subshell electrons have the greatest influence in this case. Differences in the decay constant of several tenths of a percent are observed.11,12 Attempts have been ade to explain these observations theoretically. ${ }^{12-14} \mathrm{TcO}_{4}^{-}$has a larger ahift than $\mathrm{TcX}_{6}^{2-}\left(\mathrm{X}=\mathrm{Cl}^{-}\right.$, $\mathrm{Br}^{-}$, or $\mathrm{I}^{-}$) owing to ita more ionic nature.

The best characterized aqueous Tc species is the pertechnetate ion $\mathrm{TcO}_{4}^{-}$. It is fairly stable and quite mobile in geological environments. However, when reduced to cationic forms (by $\mathrm{Fe}^{0}, \mathrm{Fe}^{2+}$, etc.), technetium is much more atrongly absorbed on minerals. 15-19 Consequently, a complete thermodynamic data base for Tc aqueous species and solids is essential for reliable modeling of Tc migration in the earth's cruat. When incomplete thermodynamic data bases are used in geochemical modeling, speciation calculations can be unreliable. One need only examine the published potential-pH diagrams for aqueous Tc to see large differences for the stability regions for various ions. $15,16,18,20,21$ Most of these calculations included aqueous $\mathrm{TcO}_{4}^{-}$and $\mathrm{Tc}^{2+}$ (and $\mathrm{Tc}^{2+}$ datum is only an estimated value). Various aqueous species of Tci.iI), Tc(IV), Tc(V), and Tc (VI) are also known, but not all of them are stable or even properly characterized.

The present report gives an assessment of the current knowledge of the chemistry and thermodynamics of Tc and some of its inorganic compounds and their aqueous solutions. Values for thermodynamic quantities are recommended when sufficient information is available. Unfortunately, in many cases, the desired data are unavailable.

A number of articles and books provide information about the inorganic chemistry, radiochemistry, thermodynamics, analytical chemistry, and uses of Tc. Several references have been cited already. $3-9,20$ Three other books provide additional information. ${ }^{22-24}$ Crystal structure data have also been reviewed recent $1 y, 25$ and a short review of analytical chemistry has appeared. 26 
ANALYSIS OF CHEMICAL AND THERHODYNAMIC DATA

DATA FOR SOLIDS, LIQUIDS, AND GASES

\section{Elenentel Technetium}

Most available technetium is produced by nuclear reactors (Oak Ridge National Laboratory is a major aupplier) and is usually in the form of an aqueous $\mathrm{NH}_{4} \mathrm{TcO}_{4}$ solution. This is generally converted to the metal or to some other compound.

One of the earliest methods of preparing high purity Tc metal involved forming a black precipitate of $\mathrm{Tc}_{2} \mathrm{~S}_{7}$ upon addition of $\mathrm{H}_{2} \mathrm{~S}$ to solution: containing $\mathrm{TCO}_{4}^{-}$. This was followed by $\mathrm{H}_{2}(8)$ reduction at 1300 to $1400 \mathrm{~K} .27$ However, very prolonged reduction is required to obtain a sulfur-free product. ${ }^{28} \mathrm{H}_{2}$ reduction of $\mathrm{NH}_{4} \mathrm{TcO}_{4}(\mathrm{c})$ lso gives good results in an inert atmosphere, ${ }^{29}$ but in the presence of $\mathrm{NH}_{3}(g)$ a nitride is obtained.

Thermal deconposition of hexahalotechnetates $\mathrm{M}_{2} \mathrm{TcX}_{6}(\mathrm{c})$ also yields metallic technetium. Pure Tc is obtained from the ammonium salt, ${ }^{30-32}$ but alkali metal salts are a by-product of the thermal decomposition of alkali metal hexahalotechnetates. 32,33 Electrolysis of $\mathrm{TcO}_{4}^{-}$ion in $\mathrm{H}_{2} \mathrm{SO}_{4}$ solutions gives very pure metal, 30,34 but $\mathrm{H}_{2} \mathrm{O}_{2}$ addition is essential to eliminate $\mathrm{TCO}_{2} \mathrm{mH}_{2} \mathrm{O}$ formation during the electroreduction. Electroreduction of $\mathrm{TcO}_{4}^{-}$at a mercury cathode yields either an amalgam or a fine dispersion. 30

Three determinations of the melting point of Tc are in reasonably good agreement: $2413 \pm 20 \mathrm{k},{ }^{35} 2473 \pm 50 \mathrm{k},{ }^{36}$ and $2435 \pm 40 \mathrm{k} \cdot{ }^{37}$ The selected value is the average $2440 \pm 30 \mathrm{~K}$. Stull and Sinke's ${ }^{38}$ estimated boiling point of $4900 \mathrm{~K}$ was accepted here since no experimental values are available.

Published heat capacity data are available for Tc metal only from 3 to $15 \mathrm{~K}$ (TC is superconducting below about $7.8 \mathrm{~K}$ ). ${ }^{39}$ Pulsed heating was used to reduce interference due to radioactive self-heating. These data above $7.86 \mathrm{~K}$ yield a Debye constant $\theta_{D}=454 \pm 4 \mathrm{~K}$ and an electronic heat capacity coefficient $\gamma=4.30 \pm 0.05 \mathrm{~mJ} / \mathrm{mol}-\mathrm{K}^{2}$. The $\theta_{\mathrm{D}}$ value agrees with the value from low temperature ultrasonic velocity measurements. 40 Values of $\theta_{D}$ depend slightly on temperature 40 as is usual for metals. Since no higher temperature heat capacities exist, stull and Sinke's 
estimates $^{38}$ of $s^{\circ}(298 \mathrm{~K})=33.5 \mathrm{~J} / \mathrm{mol}-\mathrm{K}$ and $\mathrm{C}_{\mathrm{P}}(298 \mathrm{~K})=24.3 \mathrm{~J} / \mathrm{mol}-\mathrm{K}$ were accepted for the solid. This entropy is relative to normal state (nonsuperconducting) low-temperature Tc.

Hetallic Tc has a hcp (hexagonal, close-packed) structure, and 7 unitcell determinations are in fairly good agreement. $29,41-46$ The four sets in best agreement ${ }^{29,42-44}$ were averaged to obtain "best values" of a $=2.741$ $\pm 0.001 \mathrm{~A}$ and $c=4.399 \pm 0.001 \mathrm{~A}$. Marples and $\mathrm{Koch}^{44}$ also studied the cell dimensions from 4.2 to $298 \mathrm{~K}$ and obtained theraal expanaion coefficient: (valid from 150 to $298 \mathrm{~K}$ ) of $\alpha_{a}=7.0_{4} \times 10^{-6} \mathrm{x}^{-1}$ and $a_{c}=7.0_{6} \times 10^{-6} \mathrm{k}^{-1}$. Electronic bandatructure calculatione have been reported for hcp Tc. 47

Two determinations of the enthalpy of sublimation of Tc(c) are $638.9 \pm 9.2 \mathrm{~kJ} / \mathrm{mol}^{37}$ and $661 \pm 17 \mathrm{~kJ} / \mathrm{mol},{ }^{48}$ from third-law analysis of Knudsen masa spectrometry. They are in good agreement and also agree with Stull and Sinke's estimated value of $649 \mathrm{~kJ} / \mathrm{mol} .38$ We accept the experimental average of $650 \pm 11 \mathrm{~kJ} / \mathrm{mol}$. While the two third-1aw values agree, the second-law values differ by over $200 \mathrm{~kJ} / \mathrm{mol}$ and are much less reliable. Only monatomic $\mathrm{Tc}^{+}(\mathrm{g})$ was detected in the vapor phase. Since the vapor pressures also differ by factors of 3 to 6 between these two studies, no free-energy data are recomended. Stull and sinke ${ }^{38}$ have also estimated the enthalpy of vaporization of liquid Tc to be $577 \mathrm{KJ} / \mathrm{mol}$.

Values of the heat capacity and entropy have been calculated by statistical mechanical methods for monatomic Tc vapor. ${ }^{38,49}$ Recomended values at $298 \mathrm{~K}$ are $\mathrm{Cp}_{\mathrm{p}}=20.8 \mathrm{~J} / \mathrm{mol}-\mathrm{K}$ and $\mathrm{s}^{\circ}=181.0 \mathrm{~J} / \mathrm{mol}-\mathrm{K}$. Table 1 contains a summary of recommended thermodynamic and atructural data for elemental Tc.

Metallic Alloys and Hydrides

These data mainly consist of partial phase diagrams, with very little thermodynamic data. Peacock ${ }^{7}$ and Lavrukhina and Pozdynakov ${ }^{6}$ cite references for many of the metallic alloys. See especially the paper by Niemiec. 50 Results for the Fe-Tc phase diagran have been reviewed but are . fragmentary. 51 Spitsyn et $a 1.46,52$ have investigated the hcp Tc hydride system. There are insufficient data to recomend thermodynamic values for any of these compounds. 
TABLE 1. Recomended data for elemental Tc.

Type of property

Value

Melting point, $K$

Boiling point, $K$

Debye constant, $K$

Electronic heat capacity

coefficient, $=\mathrm{J} / \mathrm{w} 1-\mathrm{K}^{2}$

Entropy (298 K) of solid, J/mol-K

Heat capacity $(298 \mathrm{~K})$ of solid, J/aol-K

Unit cell a-dimansion, $A$

Unit cell c-dinension, $A$

Therael expension axis, $\mathrm{k}^{-1}$

Theranl expansion c-axis, $\mathrm{K}^{-1}$

Enthalpy of sublimation, $\mathrm{KJ} / \mathrm{mol}$

Enthalpy of vaporization, $\mathrm{KJ} / \mathrm{mol}$

Entropy of gas $(298 \mathrm{~K}), \mathrm{J} / \mathrm{mol}-\mathrm{K}$

Heat cepacity of gas $(298 \mathrm{~K}), \mathrm{J} / \mathrm{mol}-\mathrm{K}$
$2440 \pm 30$

$\because 4900$

$454 \pm 3$

$4.30 \pm 0.05$

$-33.5$

- 24.3

$2.741 \pm 0.001$

$4.399 \pm 0.001$

$7.04 \times 10^{-6}$

$7.06 \times 10^{-6}$

$650 \pm 11$

- 577

181.0

20.8

Colton et $21 .^{53}$ found that polarographic reduction of $\mathrm{TcO}_{4}^{-}$in chloride-containing solutions corresponds to an approxiantely $8 \mathrm{e}^{-}$reduction to a $\mathrm{Tc}^{-}$species. However, wot Tc solution electrochemiatry is irreveraible so the extent of reduction is not compiately certain (their data could also be interpreted as 7,9 , or $10 \mathrm{e}^{-}$reductions). Flosa and Grosse 54 reduced Tc labeled $\mathrm{NH}_{4} \mathrm{ReO}_{4}$ with potassiun in ethylenedianine and obtained a Re-Tc hydride. They assumed that Tc and Re compounds would be isostructural, and concluded that they had prepared a Tc analogue of $\mathrm{KReH}_{4} \cdot 2 \mathrm{H}_{2} \mathrm{O}$. Ginsterg ${ }^{55}$ prepared isostructural Tc and Re conpounda, and shomed that the Tc compound was $\mathrm{K}_{2} \mathrm{TcH}_{9}(\mathrm{c})$ since the structure of the Re analogue was known. A MR study of Ginsberg's type of material confirms the presence of $\mathrm{Tch}_{9}^{2-}$ ions in basic solution. 56 A wolecular orbital description of the $\mathrm{TcH}_{9}^{2-}$ anion has been given. 57

Small amounts of $\mathrm{K}_{2} \mathrm{TcH}_{9}(\mathrm{c})$ can be dissolved in cold concentrated aqueous base with little deconposition. However, in dillute base, and in acidic solutions, decomposition with $\mathrm{H}_{2}$ evolution is rapid. 55 
Many potential diagrans for Tc list an estimated electrode potential of $-0.5 \mathrm{~V}$ for $\mathrm{Tc} / \mathrm{Tc}^{-}$. Since the only hydride species identified so far are $\mathrm{TcH}_{9}^{2-}$ and $\mathrm{TcH}_{4}^{-}$, clains for a "Tc" species may refer to $\mathrm{TcH}_{4}^{-}$. The evidence for $\mathrm{K}_{2} \mathrm{TcH}_{9}$ is atrongest since it is backed up by structural data for both the solid state 55 and for aqueous solution. 56

Anhydrous $\mathrm{Tc}_{2} \underline{O}_{7}(\mathrm{c})$ and $\mathrm{Tc}_{2} \underline{0}_{7} \underline{(\mathrm{s})}$

The most thoroughly characterized oxide of Tc is the yellow heptoxide $\mathrm{Tc}_{2} \mathrm{O}_{7}$. It was originally prepared by direct combustion of Tc metal. 58 It's welting point is $392.7 \mathrm{~K}$ by direct determination ${ }^{58}$ and $391.6 \mathrm{~K}$ from the intersection of the liquid and solid vapor pressure curves. 59 Extrapolation of the liquid vapor pressure curve gives an estimated boiling point of $584 \mathrm{~K}$. 59 A "volatile oxide" was described by Fried et $a 1.28$ and was assumed by then to be $\mathrm{TcO}_{3}$. It was more likely $\mathrm{Tc}_{2} \mathrm{O}_{7}$. Several propertiea of $\mathrm{Tc}_{2} \mathrm{O}_{7}$ have been reported including magnetic auseptibilities ${ }^{60}$ of the solid, and Ranan spectra of the solid, liquid, and gas. 61

Aqueous solutions of $\mathrm{Tc}_{2} \mathrm{O}_{7}$ contain the very strong acid $\mathrm{HTcO}_{4}$, which can be neutralized to form a wide variety of pertechnetate salta. Concentrating aqueous HTcO $_{4}$ solutions over concentrated $\mathrm{H}_{2} \mathrm{SO}_{4}$ produced a color change from yellow to dark yellow to red to dark red. Red crystals of $\mathrm{TC}_{2} \mathrm{O}_{7} \cdot \mathrm{H}_{2} \mathrm{O}$, or anhydrous $\mathrm{HTCO}_{4}$ ' are ultimately formed. 58

Two deterninations have been reported for the enthalpy of formation of $\mathrm{Tc}_{2} \mathrm{O}_{7}(\mathrm{c})$ : (1) Cobble et $1 . .^{62}$ did direct combustion of $\mathrm{Tc}(\mathrm{c})$ and obtained $\Delta H_{f}^{O}=-1113 \mathrm{KJ} / \mathrm{mol}$, and (2) Gayer et $a 1.63$ used $\mathrm{HgO}$ to oxidize $\mathrm{Tc}(\mathrm{c})$ and obtained $-1128 \mathrm{~kJ} / \mathrm{mol}$. The best value is the average of $-1120 \pm 8 \mathrm{~kJ} / \mathrm{moi}$.

There is no direct determination of the free energy or entropy of formation of $\mathrm{Tc}_{2} \mathrm{O}_{7}(\mathrm{c})$. However, the entropy of $\mathrm{KTcO}_{4}(\mathrm{c})$ has been determined calorinetrically by Busey et $a 1.64$ to be $164.8 \mathrm{~J} / \mathrm{mol}-\mathrm{x}$. Asauning additivity relations apply, and an entropy of 38.5 sor $\mathrm{x}^{+}$in the crystal, ${ }^{62}$ then the entropy of $\mathrm{HTcO}_{4}(\mathrm{c}$ ) i. $164.8-38.5=126.3 \mathrm{~J} / \mathrm{mol}-\mathrm{K}$. The entropy of $\mathrm{Tc}_{2} \mathrm{O}_{7}(\mathrm{c})$ is related to this by

$$
s^{0}\left[\operatorname{Tc}_{2} O_{7}(c)\right]=2 s^{0}\left[\operatorname{HTcO}_{4}(c)\right]-s^{0}\left[H_{2} O(1)\right]-\Delta s_{r \times n}^{0},
$$


where $\Delta S_{\text {rxn }}^{\circ}$ epplies to the reaction

$$
\mathrm{Tc}_{2} \mathrm{O}_{7}(\mathrm{c})+\mathrm{H}_{2} \mathrm{O}(1)=2 \mathrm{HTCO}_{4}(\mathrm{c})
$$

Snith et al.' ' decomposition vapor pressure mesurements 59 yield $\Delta S_{\text {rxn }}^{0}=16.7 \pm 0.8 \mathrm{~J} /=01-\mathrm{K}$. Thus, at $298 \mathrm{~K}$,

$\mathrm{s}^{\mathrm{O}}\left[\mathrm{Tc}_{2} \mathrm{O}_{7}(\mathrm{c})\right]=2(126.3)-69.93-16.7=166.0 \pm 13$ simol-K.

The entropy of formation of $\mathrm{Te}_{2} \mathrm{O}_{7}(\mathrm{c})$ is then

$$
\begin{aligned}
\Delta S_{f}^{o}\left[\operatorname{Tc}_{2}{ }_{7}(c)\right] & =S^{\circ}\left[\mathrm{Tc}_{2} \mathrm{O}_{7}(\mathrm{c})\right]-2 \mathrm{~S}^{\mathrm{O}}[\mathrm{Tc}(\mathrm{e})]-7 / 2 \mathrm{~S}^{\mathrm{O}}\left[\mathrm{O}_{2}(\mathrm{~g})\right] \\
& =-618.6 \pm 13 \mathrm{~J} /=01-\mathrm{K} .
\end{aligned}
$$

Combining enthelpy and entropy data give the free energy of formation

$$
\begin{aligned}
\Delta G_{f}^{0}\left[\mathrm{Tc}_{2} \mathrm{O}_{7}(\mathrm{c})\right] & =\Delta \mathrm{H}_{\mathrm{f}}^{\mathrm{O}}\left[\mathrm{Tc}_{2} \mathrm{O}_{7}(\mathrm{c})\right]-\mathrm{T} \Delta \mathrm{S}_{\mathrm{f}}^{\mathrm{O}}\left[\mathrm{Tc}_{2} \mathrm{O}_{7}(\mathrm{c})\right] \\
& =-1120-298.15(-618.6)\left(10^{-3}\right) \\
& =-935.6 \pm 15 \mathrm{~kJ} / \mathrm{mol} .
\end{aligned}
$$

Smith et $a 1.59$ atudied the vepor pressures of $\mathrm{Tc}_{2} \mathrm{O}_{7}(\mathrm{c})$, which allows one to calculate date for the sublination of $\mathrm{Tc}_{2} \mathrm{O}_{7}(\mathrm{c})$ to the standard state of unit fugacity:

$$
\begin{aligned}
& \Delta G_{\text {subl }}^{\circ}=48.1 \mathrm{KJ} / \mathrm{mol}, \\
& \Delta H_{\text {sub1 }}^{\circ}=132.6 \mathrm{~kJ} / \mathrm{mol}, \text { and } \\
& \Delta S_{\text {subl }}^{\circ}=283.4 \mathrm{~J} / \mathrm{mol}^{-\mathrm{K}} .
\end{aligned}
$$

Combining the sublimation date with the crystal formation reaults yields 


$$
\begin{aligned}
& \Delta G_{f}^{O}\left[\mathrm{Tc}_{2} \mathrm{O}_{7}(\mathrm{~g})\right]=-998.5 \pm 16 \mathrm{KJ} / \mathrm{mol} \\
& \Delta H_{f}^{O}\left[\mathrm{Tc}_{2} \mathrm{O}_{7}(\mathrm{~g})\right]=-987.4 \pm 10 \mathrm{KJ} / \mathrm{mol} \\
& s^{\circ}\left[\mathrm{Tc}_{2} \mathrm{O}_{7}(\mathrm{~g})\right]=449.4 \pm 13 \mathrm{~J} / \mathrm{mol}-\mathrm{K}
\end{aligned}
$$

at $298 \mathrm{~K}$.

Glidewel1 $1^{65}$ has calculated an enthalpy of $-4603 \mathrm{~kJ} / \mathrm{mol}$ for the gas-phase reaction

$$
\mathrm{Tc}_{2} \mathrm{O}_{7}+\mathrm{O}^{2-}-2 \mathrm{TcO}_{4}^{-}
$$

Anhydrous $\mathrm{TcO}_{2}(\mathrm{c})$ and $\mathrm{TcO}_{3}(\mathrm{c})$

Like many transition metals, Tc forms a crystelline dioxide $\mathrm{IcO}_{2}(\mathrm{c})$. It has a distorted rutise atructure. ${ }^{25}$ Two structural determinations are in fair agreement, ${ }^{43,66}$ but the three unit-ceil dimensions are known only to a few hundredths of an angstrom. Vinogradov et $a \lambda .67$ reported interplaner spacings for " $\mathrm{TcO}_{2}$ " that are rither different than for the other two studies. Electron band calcuiations have been ande for $\mathrm{Tc}_{2} \mathrm{O}_{10}^{2-}$ cluaters in $\mathrm{TcO}_{2}(\mathrm{c}) .68$

$\mathrm{TcO}_{2}(\mathrm{c})$ is frequent $\mathrm{yy}$ prepared by the thermal decompocition of $\mathrm{NH}_{4} \mathrm{TcO}_{4}(\mathrm{c})$ in a. inert atmosphere. $3,3,67$ Direct combustion of Tc (c) is unsatisfactory since $\mathrm{TcO}_{2}$ readily oxidizes to $\mathrm{Tc}_{2} \mathrm{O}_{7}{ }^{3}$

No experimental therwodynamic data are avajlable for $\mathrm{TcO}_{2}(\mathrm{c})$, although it should be possible to $\mathrm{cxi}^{-}$iize $\mathrm{TcO}_{2}(\mathrm{c})$ to $\mathrm{Tc}_{2} \mathrm{O}_{7}(\mathrm{c})$ to obtain an enthalpy of formation. Decompsition pressure weasurenents are frequently used to get free energies of formation. However, $\mathrm{TCO}_{2}(s)$ sublimes unchanged above about $1200 \mathrm{~K}, 3,43$ so this nethod can not be used here.

There is no convincing experiwental evidence for $\mathrm{TcO}_{3}(\mathrm{c})$, although there are unconfirwed reports of red or purple oxide with this compisiticn. 22 However, Cobble et a1. ${ }^{62}$ have estimated its thermodynamic properties to be $\Delta \mathrm{H}_{\mathrm{f}}^{\mathrm{O}}=-540 \mathrm{KJ} / \mathrm{mol}$, $\Delta G_{f}^{0}=-461 \mathrm{KJ} / \mathrm{nol}$, and $\mathrm{s}^{\circ}=72.4 \mathrm{~J} / \mathrm{mol}-\mathrm{K}$ at $298 \mathrm{~K}$. Fried et $\mathrm{al}^{28}$

converted Tc to "the volatile oxide" and suggented this oxide was $\mathrm{TcO}_{3}$. However, $\mathrm{Tc}_{2} \mathrm{O}_{7}$ seen wore likely. Steffen and Bichmann ${ }^{69}$ did a hightemperature cinromatographic atudy of Tc heated in flowing $\mathrm{O}_{2}$, ard concluded that two volatile oxides were present which they thought were $\mathrm{TcO}_{2}\left(\mathrm{~g}_{8}\right)$ and 
$\mathrm{TcO}_{3}(\mathrm{~g})$. The " $\mathrm{TcO}_{3}(8)$ " yield decreases with decreasing temperature, and upon condensation decomposes to form $\mathrm{TcO}_{2}$. That is

$$
\mathrm{TcO}_{3}(\mathrm{c})=\mathrm{TcO}_{2}(\mathrm{c})+1 / 2 \mathrm{O}_{2}(\mathrm{~g})
$$

is thermodynamically favored. This could explain why $\mathrm{TcO}_{3}(\mathrm{c})$ has not been eatablished.

Anhydrous Solid Ternary Oxides

Valence states of metals that are unatable for the pure binary oxides are sometimes stablized in ternary oxides. They are of some interest because they indicate what valence states could occur in other solid compounds (e.8. oxyhalides), and in aqueout solutions. Only a few typical conpounds will be given from the many that have been reported. $43,70-72$ Pertechnetate salts are a very important class and will be diacussed in more detail in another section.

Examples of $\mathrm{Tc}(\mathrm{VII})$ compounds include $\mathrm{Li}_{5} \mathrm{TcO}_{6}, \mathrm{Na}_{3} \mathrm{TcO}_{5}, \mathrm{Ba}\left(\mathrm{TcO}_{4}\right)_{2}, \mathrm{Ba}_{3}\left(\mathrm{TcO}_{5}\right)_{2}$, and $\mathrm{Ba}_{5}\left(\mathrm{TcO}_{6}\right)_{2}$. Examples of $\mathrm{Tc}(\mathrm{VI})$ compounds are $\mathrm{Li}_{4} \mathrm{TcO}_{5}, \mathrm{Li}_{6} \mathrm{TcO}_{6}$, and $\mathrm{Ba}_{3} \mathrm{Tc}_{2} \mathrm{O}_{9}$. $\mathrm{Tc}$ (IV) double oxides are represented by $\mathrm{Li}_{2} \mathrm{TcO}_{3}, \mathrm{Na}_{4} \mathrm{TcO}_{4}, \mathrm{Ba}_{2} \mathrm{TcO}_{4}, \mathrm{SrTcO}_{3}$, and $\mathrm{Sm}_{2} \mathrm{Tc}_{2} \mathrm{O}_{7} \cdot \mathrm{NaTcO}_{2}$ has been prepared for $\mathrm{Tc}(\mathrm{III})$, and $\mathrm{NaTcO}_{3}$ and $\mathrm{Li}_{3} \mathrm{TcO}_{4}$ for $\mathrm{Tc}(\mathrm{V})$. Valences of IV, VI, and VII predominate.

Hydrated $\mathrm{TcO}_{2}(\mathrm{am})$

A black amorphous hydrated dioxide of Tc is one of the most thoroughly studied compounds. It can be prepared by reduction of aqueous pertechnetates with metallic zinc, ${ }^{3}$ electrolytically, ${ }^{3,45,73}$ with $\mathrm{Sn}^{2+}$ perchlorate, 74 or with certain other reducing agents. It is sparingly soluble in acidic solutions ${ }^{73}$ and usually has a composition close to the dihydrate $\mathrm{TcO}_{2} \cdot 2 \mathrm{H}_{2} \mathrm{O}$. It can be reoxidized chemically, electrolytically, or with $\gamma$-rays to form $\mathrm{TcO}_{4}^{-}$ions (see below).

$\mathrm{TcO}_{2} \cdot 2 \mathrm{H}_{2} \mathrm{O}$ is generally considered to be a hydrated dioxide but, since it is amorphous, x-ray diffraction provides little information. Its IR spectrum has few features to help identify its nature. ${ }^{45}$ Some authors consider it to be the tetrahydroxide $\mathrm{Tc}(\mathrm{OH})_{4}$ instead. Below $\mathrm{pH}=\propto 1.3$ in 
aqueous solution, $\mathrm{Tc}(\mathrm{IV})$ exists as $\mathrm{TcO}^{2+}$ [or $\left.\mathrm{Tc}(\mathrm{OH})_{2}^{2+}\right]^{74}$ slightly above $\mathrm{pH}=\approx 1.3$ it hydrolyzes ${ }^{74-76}$ to form $\mathrm{TcO}(\mathrm{OH})^{+}$[or $\left.\mathrm{Tc}_{\mathrm{COH}}\right)_{3}^{+}$, etc], $\mathrm{TcO}(\mathrm{OH})_{2}^{\circ}$, and $\left[\mathrm{TcO}(\mathrm{OH})_{2}\right]_{2}^{\circ}$. Colloidal suspensions are also known. $\mathrm{TcO}_{2} \cdot 2 \mathrm{H}_{2} \mathrm{O}$ untimately precipitates from these solutions. Only the solid will be considered in this section.

Cobble et al. 62 measured electrode potentials for the aqueous reactions

$$
\mathrm{TcO}_{2} \cdot 2 \mathrm{H}_{2} \mathrm{O}=\mathrm{TcO}_{4}^{-}+4 \mathrm{H}^{+}+3 \mathrm{e}^{-}
$$

in acidic solution, and

$$
\mathrm{TcO}_{2} \cdot 2 \mathrm{H}_{2} \mathrm{O}+4 \mathrm{OH}^{-}=\mathrm{TcO}_{4}^{-}+4 \mathrm{H}_{2} \mathrm{O}+3 \mathrm{e}^{-}
$$

in basic solution. To calculate free energies of formation of $\mathrm{TcO}_{2} \cdot 2 \mathrm{H}_{2} \mathrm{O}$ requires free energy of formation data for $\mathrm{OH}^{-}(\mathrm{aq}), \mathrm{H}_{2} \mathrm{O}(1)$, and $\mathrm{TcO}_{4}^{-}(\mathrm{aq})$. CODATA values of $\Delta G_{f}^{0}$ were used for $O H^{-}$and $H_{2} O$. The $\Delta G_{f}^{\circ}$ of $\mathrm{TcO}_{4}^{-}(\mathrm{aq}),-621.1 \mathrm{~kJ} / \mathrm{mol}$, will be derived in the aqueous solution section of this report. Cobble et al.'s data thus yield $\Delta G_{\mathrm{f}}^{\circ}\left[\mathrm{TcO}_{2} \cdot 2 \mathrm{H}_{2} \mathrm{O}(\mathrm{am})\right]$ $=-850.2 \pm 10.5 \mathrm{~kJ} / \mathrm{mol}$.

Cartledge and Smith ${ }^{77}$ reinvestigated the aqueous cell involving $\mathrm{TcO}_{2} \cdot 2 \mathrm{H}_{2} \mathrm{O} / \mathrm{TcO}_{4}^{-}$in acidic solution. They found the reaction was sluggish at $298 \mathrm{~K}$, and was affected by the presence of $0_{2}$. Since Cobble et al. 62 did not exclude air, Cartledge and Smith ${ }^{77}$ concluded that the earlier results were slightly in error. Their new potential measurement gave $\Delta G_{\mathrm{F}}^{0}\left[\mathrm{TcO}_{2} \cdot 2 \mathrm{H}_{2} \mathrm{O}\right]$ $=-837.2 \pm 10.0 \mathrm{~kJ} / \mathrm{mol}$. Cartledge ${ }^{78}$ also measured corrosion potentials, which yield $-835.3 \pm 2.5 \mathrm{KJ} / \mathrm{mol}$ for a surface film of $\mathrm{TcO}_{2} \cdot 2 \mathrm{H}_{2} \mathrm{O}$. The last two values were averaged to produce the recomended value $\Delta \mathrm{G}_{\mathrm{f}}^{\circ}\left[\mathrm{TcO}_{2} \cdot 2 \mathrm{H}_{2} \mathrm{O}(\mathrm{am})\right]=-836.3 \pm 7.0 \mathrm{~kJ} / \mathrm{mol}$ at $298 \mathrm{~K}$. 


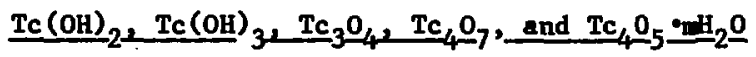

Cartledge 78 measured a number of stationary "corrosion" potentials for Tc in aqueous $\mathrm{H}_{2} \mathrm{SO}_{4}$ at $297 \mathrm{~K}$. Several of these were also obtained iti another of his studies. 79 Gartledge attributed them to lower oxides or hydroxides of Tc. His assignment of the chemical formulas will be accepted [except for $\mathrm{TcO}_{2} \cdot 2 \mathrm{H}_{2} \mathrm{O}$ instead of $\left.\mathrm{Tc}(\mathrm{OH})_{4}\right]$ for want of any unambigious criteria for distinguishing hydroxides fron hydrated oxides. However, the identification of $\mathrm{Tc}_{4} \mathrm{O}_{7}$ as one of these compounds is not completely certain.

Using our results for $\Delta G_{f}^{\circ}\left(\left[\mathrm{TcO}_{2} \cdot 2 \mathrm{H}_{2} \mathrm{O}\right]\right.$ and the CODATA value for $\mathrm{H}_{2} \mathrm{O}(1)$ allows us to calculate the following values:

$$
\begin{aligned}
& \Delta G_{f}^{0}[\mathrm{TcOH}]=-234.7 \pm 3.8 \mathrm{~kJ} / \mathrm{mol} \\
& \Delta \mathrm{G}_{\mathrm{f}}^{\mathrm{O}}\left[\mathrm{Tc}(\mathrm{OH})_{2}\right]=-461.2 \pm 3.8 \mathrm{KJ} / \mathrm{mol} \\
& \Delta G_{f}^{\circ}\left[\mathrm{Tc}(\mathrm{OH})_{3}\right]=-658.5 \pm 3.8 \mathrm{~kJ} / \mathrm{mol} \\
& \Delta G_{f}^{o}\left[\mathrm{Tc}_{3} \mathrm{O}_{4}\right]=-863.8 \pm 3.8 \mathrm{KJ} / \mathrm{mol}
\end{aligned}
$$

and

$$
\Delta G_{f}^{0}\left[\mathrm{Tc}_{4}^{0}\right]=-1324 \pm 21 \mathrm{KJ} / \mathrm{mol}
$$

These are actually for surface films. However, for $\mathrm{TcO}_{2} \cdot 2 \mathrm{H}_{2} \mathrm{O}$ the difference from bulk phase was fairly sma11, so they can also be applied to bulk phases. Spitsyn et a1. ${ }^{80}$ reported the formation of $\mathrm{Tc}_{4} \mathrm{O}_{5} \mathrm{mH}_{2} \mathrm{O}$ from the hydrolysis of $\mathrm{Tc}_{2} \mathrm{Cl}_{8}^{3-}$. They deduced this formula since they saw little evidence for oxidation. Additional evidence for this compound would be desizable.

Table 2 contains a summary of thermodynamic data for anhydrous oxides, hydrated oxides, and hydroxides.

\section{Solid Pertechnetates}

The most thoroughly studied aqueous ion of technetium is the pertechnetate ion $\mathrm{TcO}_{4}^{-}$which is stable in environments not strongly reducing. It can be 
TABLE 2. Recommended data for oxides and hydroxides at $298 \mathrm{~K}$.

Compound Phase $\Delta G_{f}^{\circ}$ in $K J / m o l \quad \Delta H_{f}^{\circ}$ in $\mathrm{KJ} / \mathrm{mol} \quad s^{\circ}$ in $\mathrm{J} / \mathrm{mol}-\mathrm{K}$

$\begin{array}{lllll}\mathrm{Tc}_{2} \mathrm{O}_{7} & \text { Crystal } & -935.6 \pm 15 & -1120 \pm 8 & 166.0 \pm 13 \\ \mathrm{Tc}_{2} \mathrm{O}_{7} & \text { Gas } & -888.5 \pm 16 & -987.4 \pm 10 & 449.4 \pm 13 \\ \mathrm{TcO}_{3} & \text { Crystal } & -461 & -540 & =72.4 \\ \mathrm{TcO}_{2} \cdot 2 \mathrm{H}_{2} \mathrm{O} & \text { Solid (am) } & -836.3 \pm 7.0 & - & -- \\ \mathrm{TcOH} & \text { Solid (am?) } & -234.7 \pm 3.8 & - \\ \mathrm{Tc}(\mathrm{OH})_{2} & \text { Solid (am?) } & -461.2 \pm 3.8 & -- \\ \mathrm{Tc}_{\mathrm{O}}(\mathrm{OH})_{3} & \text { Solid (am?) } & -658.5 \pm 3.8 & - \\ \mathrm{Tc}_{3} \mathrm{O}_{4} & \text { Solid (am?) } & -863.8 \pm 3.8 & -- \\ \mathrm{Tc}_{4} \mathrm{O}_{7} & \text { Solid (am?) } & -1324 \pm 21 & - & - \\ \end{array}$

prepared by oxidation of almost any lower valense aqueous species or suspended solid in aqueous solution. Dissolution of $\mathrm{Tc}_{2} \mathrm{O}_{7}$ in $\mathrm{H}_{2} \mathrm{O}$ gives a solution of $\mathrm{HTcO}_{4}$ which can be neutralized to provide a wide variety of salts. Many of these have been isolated as solid compounds.

A number of solid pertechnetates have veen prepared and partially characterized by $x$-ray diffraction powder pattern data and, in some cases, by

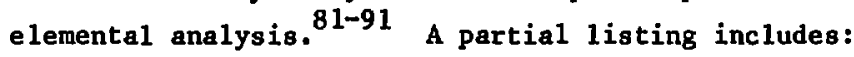
$\mathrm{NaX}, \mathrm{KX}, \mathrm{RbX}, \mathrm{CsX}, \mathrm{NH}_{4} \mathrm{X}, \mathrm{AgX}, \mathrm{T} 1 \mathrm{X}, \mathrm{MgX}_{2} \cdot 4 \mathrm{H}_{2} \mathrm{O}, \mathrm{MgX}_{2} \cdot 2 \mathrm{H}_{2} \mathrm{O}, \mathrm{MgX}_{2}, \mathrm{PbX}_{2} \cdot 2 \mathrm{H}_{2} \mathrm{O}, \mathrm{PbX}{ }_{2}$, $\operatorname{CdX}_{2} \cdot 2 \mathrm{H}_{2} \mathrm{O}, \operatorname{CdX}_{2}, \mathrm{ZnX}_{2} \cdot 4 \mathrm{H}_{2} \mathrm{O}, \mathrm{ZnX}_{2} \cdot 2 \mathrm{H}_{2} \mathrm{O}, \mathrm{ZnX}_{2}, \mathrm{ScX}_{3} \cdot 3 \mathrm{H}_{2} \mathrm{O}, \mathrm{ScX}_{3} \bullet \mathrm{H}_{2} \mathrm{O}, \mathrm{ScX}{ }_{3}$, $\operatorname{PrX}_{3} \cdot 4 \mathrm{H}_{2} \mathrm{O}, \operatorname{PrX}_{3} \cdot \mathrm{H}_{2} \mathrm{O}, \operatorname{PrX}_{3}, \operatorname{NdX}_{3} \cdot 4 \mathrm{H}_{2} \mathrm{O}, \operatorname{NdX}_{3}{ }^{*} \mathrm{H}_{2} \mathrm{O}$, and $\operatorname{NdX}_{3} \cdot 67,81-91$

The partechnetate ion has been denoted by $X$ here for brevity. It is clear that alt it any cation can form a salt with this anion. The scheelite structure is : non for most anhydrous monovalent cation salts. Thermal decomposition of pertechnetate salts usually gives $\mathrm{TcO}_{2}(\mathrm{c})$ or a double oxide of Tc.

Aqueous solubility data have been reported as a function of temperature for $\mathrm{KTcO}_{4}, 63 \mathrm{CsTcO}_{4}, \mathrm{AgTcO}_{4}$, and $\mathrm{TlTcO}_{4}, 83$ The solubility of $\mathrm{RbTcO}_{4}$ at $293 \mathrm{~K}$ and $\mathrm{NaTcO}_{4}$ at $298 \mathrm{~K}$ have also been determined. 83,92 
The tenperature dependences of solubilities yield enthalpies of solution. Values obtained by this methor are $33.6 \mathrm{KT} / \mathrm{mol}$ for $\mathrm{TlTcO}_{4}$, $28.0 \mathrm{~kJ} / \mathrm{mol}$ for $\mathrm{CsTcO}_{4}$, and $40.3 \mathrm{~kJ} / \mathrm{mol}$ for $\mathrm{AgTcO}_{4} \cdot 83$ Direct measurement of the enthalpy of solution of $\mathrm{KTcO}_{4}$ 3ave $53.41 \mathrm{~kJ} / \mathrm{mol} .64$ Busey et al. ' 84 equation for the enthalpy of solution as a function of temperature is correct for $T={ }^{\circ} \mathrm{C}$ and no $\leqslant$ as stated by them. Busey et al. also estimated the activity coefficient of saturated $\mathrm{KTcO}_{4}(0.1057 \mathrm{~mol} / \mathrm{kg})$ at $298 \mathrm{X}$ to be $Y \pm=0.676 \pm 0.010$. This yields a frep energy of solution of $\Delta G_{s 01}^{\circ}=-R T 1 n(n \gamma \pm)_{\text {sat }}^{2}=13.06 \pm 0.13 \mathrm{~kJ} / \mathrm{mol}$, and an entropy of solution $\Delta s_{s o 1}^{0}=135.3 \pm 1.3 \mathrm{~J} / \mathrm{mol}-\mathrm{K}$.

Busey et al. ${ }^{64}$ also measured the heat cepacity of $\mathrm{KTcO}_{4}(\mathrm{c})$ from 9.00 to $308.56 \mathrm{~K}$. Their data yield a heat capacity of $123.3 \mathrm{~J} / \mathrm{mol}-\mathrm{K}$ and absolute entropy $S^{\circ}=164.78 \mathrm{~J} / \mathrm{mol}-\mathrm{K}$. An earlier unpublished study in their laboratory for $\mathrm{KTcO}_{4}$ was rejected by them because the sample was not completely anhydrous.

The above data can be used to obtain the $\Delta G$, $\Delta H$, and $\Delta S$ of formation of $\mathrm{KICO}_{4}(\mathrm{c})$, by using solution data. Also required are $\Delta \mathrm{H}_{\mathrm{f}}^{\mathrm{O}}\left[\mathrm{TcO}_{4}^{-}(\mathrm{aq})\right]=-716.3 \pm 4.5 \mathrm{~kJ} / \mathrm{mol}$, and $\Delta \mathrm{G}_{\mathrm{f}}^{\circ}\left[\mathrm{TcO}_{4}^{-}(\mathrm{aq})\right]$ $=-623.8 \pm 10.0 \mathrm{~kJ} / \mathrm{mol}$. These values will be derived in the aqueous solution section of this paper. Thus,

$$
\begin{aligned}
& \Delta G_{f}^{0}\left[K T c O_{4}(c)\right]=\Delta G_{f}^{0}\left[K T c O_{4}(a q)\right]-\Delta G_{801}^{0} \\
& =\Delta G_{f}^{0}\left[K^{+}(a q)\right]+\Delta G_{f}^{0}\left[\mathrm{TcO}_{4}^{-}(a q)\right]-\Delta G_{801}^{0} \\
& =-919.2 \pm 10.0 \mathrm{~kJ} / \mathrm{mol}
\end{aligned}
$$

A180,

$$
\begin{aligned}
\Delta \mathrm{H}_{\mathrm{f}}^{\mathrm{O}}\left[\mathrm{KTCO}_{4}(\mathrm{c})\right]=\Delta \mathrm{H}_{\mathrm{f}}^{\mathrm{O}}\left[\mathrm{KTcO}_{4}(\mathrm{aq})\right]-\Delta \mathrm{H}_{\mathrm{sol}}^{\mathrm{O}} \\
=\Delta \mathrm{H}_{\mathrm{f}}^{\mathrm{O}}\left[\mathrm{K}^{+}(\mathrm{aq})\right]+\Delta \mathrm{H}_{\mathrm{f}}^{\mathrm{O}}\left[\mathrm{TcO}_{4}^{-}(\mathrm{aq})\right]-\Delta \mathrm{H}_{\mathrm{sol}}^{\circ} \\
=-1022.2 \pm 5.5 \mathrm{~kJ} / \mathrm{mol}
\end{aligned}
$$

Boyd 92 reported isopiestic messurements for $\mathrm{NeTcO}_{4}$ solutions at $298 \mathrm{~K}$ from 0.108 to $9.464 \mathrm{~mol} / \mathrm{kg}$. He also measured the solubility to be 11.299 mol/kg. A modest extrapolation of his isopiestic data yields $\gamma \pm=0.52 \pm 0.03$ for the saturated solution. 
Thus,

$\Delta G_{\text {sol }}^{0}=-R T \ln (\mathrm{m} \Psi \pm)_{\text {sat }}^{2}=8.78 \pm 0.28 \mathrm{KJ} / \mathrm{mol}$

and

$\Delta G_{f}^{0}\left[\mathrm{NaTcO}_{4}(\mathrm{c})\right]=\Delta G_{E}^{0}\left[\mathrm{Na}{ }^{+}(\mathrm{aq})\right]+\Delta G_{f}^{0}\left[\mathrm{TeO}_{4}^{-}(\mathrm{aq})\right]-\Delta \mathrm{F}_{\mathrm{sol}}^{0}$

$$
-877.0 \pm 10.1 \mathrm{~kJ} / \mathrm{mol}
$$

For these calculations the CODATA values were used for $\Delta G_{f}^{0}$ of aqueous $\mathrm{K}^{+}$and $\mathrm{Na}^{+}$.

Smith et al. ${ }^{59}$ reported decomposition pressure date for $\mathrm{HTcO}_{4}(\mathrm{c})$ which can be combined with vaporization data for $\mathrm{H}_{2} \mathrm{O}$ to yield

$$
2 \mathrm{HTCO}_{4}(\mathrm{c})=\mathrm{H}_{2} \mathrm{O}(1)+\mathrm{Tc}_{2} \mathrm{O}_{7}(\mathrm{c})
$$

and it is not known whether the solid is actuaily $\mathrm{HTcO}_{4}$ (c) or $\mathrm{Tc}_{2} \mathrm{O}_{7} \cdot \mathrm{H}_{2} \mathrm{O}(\mathrm{c})$. Their pressure measurements yield (at $298 \mathrm{~K}$ ) $\Delta H_{\text {rxn }}^{0}=1.80 \pm 0.21 \mathrm{~kJ} / \mathrm{mol}, \Delta G_{\mathrm{rXn}}^{0}=6.83 \pm 0.08 \mathrm{~kJ} / \mathrm{mol}$, and $\Delta S_{\text {rXn }}^{0}=-16.7 \pm 0.8 \mathrm{~J} / \mathrm{mol}-\mathrm{K}$. For the decomposition reaction,

$$
\Delta H_{r \times n}^{0}=\Delta H_{f}^{0}\left[\mathrm{Tc}_{2} \mathrm{O}_{7}(\mathrm{c})\right]+\Delta \mathrm{H}_{\mathrm{f}}^{\mathrm{O}}\left[\mathrm{H}_{2} \mathrm{O}(1)\right]-2 \Delta \mathrm{H}_{\mathrm{f}}^{\mathrm{O}}\left[\mathrm{HT}^{\mathrm{T}} \mathrm{cO}_{4}(\mathrm{c})\right]
$$

Thus

$$
\begin{gathered}
\Delta \mathrm{H}_{\mathrm{f}}^{\mathrm{O}}\left[\mathrm{HTcO}_{4}(\mathrm{c})\right]=1 / 2\left(\Delta \mathrm{H}_{\mathrm{f}}^{\mathrm{O}}\left[\mathrm{Tc}_{2} \mathrm{O}_{7}(\mathrm{c})\right]+\Delta \mathrm{H}_{\mathrm{f}}^{\mathrm{O}}\left[\mathrm{H}_{2} \mathrm{O}(1)\right]-\Delta \mathrm{H}_{\mathrm{r \times n}}^{\mathrm{O}}\right) \\
=-703.8 \pm 9.6 \mathrm{KJ} / \mathrm{mol},
\end{gathered}
$$

using the CODATA value for $\mathrm{H}_{2} \mathrm{O}(1)$ and $\Delta \mathrm{H}_{\mathrm{f}}^{\mathrm{O}}\left[\mathrm{Tc}_{2} \mathrm{O}_{7}(\mathrm{c})\right]$ obtained earlier. siailar equation could be given for $\Delta \mathrm{S}_{\mathrm{f}}^{0}\left[\mathrm{HTcO}_{4}(\mathrm{c})\right]$. Unfortunately, there is no available entropy data for either $\mathrm{Tc}_{2} \mathrm{O}_{7}(\mathrm{c})$ or 
$\mathrm{HTcO}_{4}(\mathrm{c})$. Consequent1, $\mathrm{s}^{\mathrm{O}}\left[\mathrm{HTcO}_{4}(\mathrm{c})\right]$ was obtained (as earlier) from $\mathrm{s}^{\circ}\left[\mathrm{KTCO}_{4}(\mathrm{c})\right]$ asstming additivity relations apply. The estimated value is 126.3 $\mathrm{J} / \mathrm{mol}-\mathrm{K}$. The entropy of formation of $\mathrm{HTcO}_{4}(\mathrm{c})$ is then

$$
\begin{gathered}
\Delta S_{f}^{0}\left[\mathrm{HTCO}_{4}(c)\right]=\mathrm{s}^{0}\left[\mathrm{HTCO}_{4}(\mathrm{c})\right]-\mathrm{s}^{\mathrm{O}}[\mathrm{Tc}(\mathrm{c})]-2 \mathrm{~s}^{\mathrm{O}}\left[\mathrm{O}_{2}(\mathrm{~g})\right]-1 / 2 \mathrm{~s}^{\mathrm{O}}\left[\mathrm{H}_{2}(\mathrm{~g})\right] \\
=-382.5 \pm 3 \mathrm{~J} / \mathrm{mol}-\mathrm{K} .
\end{gathered}
$$

Combining results gives

$$
\begin{aligned}
\Delta G_{\mathrm{f}}^{\mathrm{O}}\left[\mathrm{HTCO}_{4}(\mathrm{c})\right]=\Delta \mathrm{H}_{\mathrm{f}}^{\mathrm{O}}\left[\mathrm{HTCO}_{4}(\mathrm{c})\right]-\mathrm{T} \Delta \mathrm{S}_{\mathrm{f}}^{\mathrm{O}}\left[\mathrm{HTCO}_{l}(\mathrm{c})\right] \\
=-589.8 \pm 10.5 \mathrm{~kJ} / \mathrm{HoO} .
\end{aligned}
$$

Solid Tetraoxotechnetates $\left(\mathrm{TcO}_{4}^{2-}\right)$

Electrolytic reduction of aqueous $\mathrm{TcO}_{4}^{-}$in noncomplexing media under different conditions can involve 1, 2, 3, or more electrons. A one electron reduction is sometimen observed in basic media, but the Tc(VI) species produced is very unstable and rapidly disproportionates to $\mathrm{TcO}_{4}^{-}$and a Tc(IV) species. Sore studies indicate the reduction potential for $\mathrm{Tc}$ (VII)/Tc(VI) is not $\mathrm{pH}$ dependent, so no oxygens should be lost from the $\mathrm{TcO}_{4}^{-}$ion. That is, the initial reduction product is the unstable $\mathrm{TcO}_{4}^{2-}$ ion.

Support for this deduction comes from the studies of Schwochau and co-workers. ${ }^{93-95}$ In certain nonaqueous media (mainly acetonitrile), reduction of $\mathrm{TcO}_{4}^{2-}$ salts yield violet $\mathrm{TcO}_{4}^{2-}$ salts. Astheimer et al. ${ }^{94}$ studied the solid tetramethyl ammonium salt $\left[\left(\mathrm{CH}_{3}\right)_{4} \mathrm{~N}\right]_{2} \mathrm{TcO}_{4}$ using IR, magnetic susceptibilities, optical spectra, and electron transfer spectra. Structural information was provided by powder pattern data. 94 Under carefully controlled conditions, up to 907 of the $\mathrm{TcO}_{4}^{-}$initially present could be converted to $\mathrm{TcO}_{4}^{2-} \cdot 95$

Salts of $\mathrm{TcO}_{4}^{2-}$ decompose in the presence of moisture 94 and are not present in significant amounts for aqueous solutions at eqilibrium. However, their presence in the solid state supports the evidence for their existence as 
intermediates in the reduction of $\mathrm{TcO}_{4}^{-} \mathrm{salts}$. No thermodynamic data have been reported for solid $\mathrm{TcO}_{4}^{2-}$ salts.

\section{Anhydrous Technetium Halides}

Early attempts to prepare Tc chlorides by direct reaction of $\mathrm{Cl}_{2}(\mathrm{~g})$ with Tc metal under static conditions were unsuccessful. ${ }^{3}$ However, it was later found that when a stream of $\mathrm{Cl}_{2}$ was used, reaction does occur. The initial reaction produces a mixture of dark green $\mathrm{TCCl}_{6}(\mathrm{c})$ and "dark" or "blood" red $\mathrm{TcCl}_{4}(\mathrm{c}) . \mathrm{TcCl}_{6}$ is very unstable, even in the presence of $\mathrm{Cl}_{2}(\mathrm{~g})$, and decomposes to form $\mathrm{TcCl}_{4}$ and $\mathrm{Cl}_{2} \cdot 96,97 \mathrm{TcCl}_{6}$ hydrolyzes and disproportionates in aqueous solution according to the reaction 96

$$
3 T c(V I)=2 \operatorname{Tc}(V I I)+\operatorname{Tc}(I V)
$$

$\mathrm{TcCl}_{4}(\mathrm{c})$ also hydrolyzes in water, 97 but in concentrated HCl solution produces the $\mathrm{TcCl}_{6}^{2-}$ ion. $\mathrm{TcCl}_{4}(\mathrm{c})$ can be sublimed in a $\mathrm{Cl}_{2}(8)$ stream. 97

$\mathrm{TcCl}_{4}$ has also been prepared by the reaction of $\mathrm{Tc}_{2} \mathrm{O}_{7}$ with $\mathrm{CCl}_{4}{ }^{\circ}$ Crystal structure data have been reported, 97,99 but no thermodynamic data are available for $\mathrm{TcCl}_{4}$. Thermodynamic data have been estimated for $\mathrm{TCCl}_{3}$ by Brewer et al., ${ }^{100}$ but there is no experimenta! evidence for its existence. 101 A large number of monomeric, dimeric, and trimeric Tc chloride cluster ions have been detected in the vapor phase by mass spectrometry. 102 a gas chromatographic study ${ }^{103}$ of $\mathrm{Tc}(\mathrm{c})-\mathrm{Cl}_{2}(\mathrm{~g})$ at high temperatures indicated two volatile $\mathrm{TcCl}_{\mathrm{x}}$ species, which the authors thought were $\mathrm{TcCl}_{4}$ and $\mathrm{TcCl}_{5}$ * More direct evidence for $\mathrm{TcCl}_{5}$ would be desirable, since most pentavalent Tc compounds are thermodynamically unstable.

Technetium bromides have been studied even 1ess. Direct reaction of $\mathrm{Br}_{2}$ with $\mathrm{Tc}$ does not seem to be favorable, but oxidation of Tc with $\mathrm{H}_{2} \mathrm{O}_{2}$ followed by evaporation with $\mathrm{HBr}$ produced solid $\mathrm{TCBr}_{4} \cdot 101$ This compound is brown-red, and hydrolyzes in moist air. Tsalas and Bächmann 104 found evidence for it in their high-temperature gas chromatographic study. No descriptions of $\mathrm{TcI}_{x}$ compounds were found. Brewer et a1. 100 estimated thermodynamic data for $\mathrm{TcBr}_{3}, \mathrm{TcI}_{3}, \mathrm{TcBr}_{5}$, and $\mathrm{TcI}_{5}$, none of which have been isolated. 
Both $\mathrm{TCF}_{5}$ and $\mathrm{TCF}{ }_{6}$ are known, but only $\mathrm{TCF}_{6}$ has been studied in any detail. ${ }^{24} \mathrm{TcF}_{6}$ exists in two crystalline modifications, and unit cell dimensions have been reported for both forms. 105 Raman spectr: are available for TCF $_{6}$ vapor. 106

Detailed thermodynamic data are also available for $\mathrm{TcF}_{6} \cdot$ Selig and Malm 107 measured vapor pressures of the iwo solid crystalline modifications and of the liquid. The solid-solid phase transition occurs at $268.34 \mathrm{~K}$, and the melting point is $311.14 \pm 0.05 \mathrm{~K} .108$ Intersection of the vapor pressure curves gave $310.6 \mathrm{~K}, 107$ which is in reasonable agreement with the directly measured melting point.

Osborne et al. 108 have perforwed a careful and detailed study of the heat

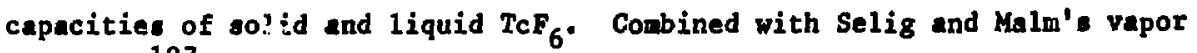
pressures 107 they yield data for gaseous $\mathrm{TcF}_{6}$ also. Results at $298 \mathrm{~K}$ for the high-temperature solid are $157.85 \mathrm{~J} / \mathrm{mol}-\mathrm{K}$ for the heat capacity and $253.52 \pm 0.25$ Jimol-K for entropy. Their third law results for the vapor phase are 120.92 $\mathrm{J} / \mathrm{mol}-\mathrm{K}$ for heat capacity and $371.28 \pm 0.75 \mathrm{~J} / \mathrm{mol}-\mathrm{K}$ for entropy. They calculated an entropy of $367.52 \mathrm{~J} / \mathrm{wol}-\mathrm{K}$ using spectroscopic data and statistical calculations, and the agreement is fairly good. 108 Another statistical calculation ${ }^{109}$ gave much lower results.

Hexahalotechnetate (IV) Salts

Te(IV) in aqueous solution exists in a variety of hydrolyzed forms. At very high concentrations of halogen ions, complexes of the type $\mathrm{Tcx}_{6}^{2-}$ form. $^{2}$ Direct evidence for this comes from solid compounds containing this anion. Even the free acid $\mathrm{H}_{2}\left[\mathrm{TcCl}_{6}\right] \cdot 9 \mathrm{H}_{2} \mathrm{O}(\mathrm{c})$ has been prepared and its crystal structure investigated. 110,111 Most $\mathrm{K}^{+}, \mathrm{Rb}^{+}, \mathrm{Cs}^{+}$, and $\mathrm{NH}_{4}^{+}$salts of $\mathrm{TcF}_{6}^{2-}, \operatorname{TcCl}_{6}^{2-}, \mathrm{TcBr}_{6}^{2-}$, and $\mathrm{TcI}_{6}^{2-}$ have been reported. $8,25,31,33,112-118$ Some of these salts have been studied by x-ray diffracion, IR, Raman, and in some cases, magnetic susceptibilities. Thermal decomposition of them generally gives metallic Tc. Transition metal hexahalonetallates undergo solid-state structural transitions, and the transition tenperature for each fixed alkali metal cation increases with the atomic number of the anion. 117 The hydrazine salt $\mathrm{N}_{2} \mathrm{H}_{6} \mathrm{TCF}_{6}$ forms in anhydrous HF but it is fairly unstable. 119 Chloride salts of the protonated forms of pyridine, dipyridine, and quinoline have also been reported, 120,121 
Vinogradov et al. 122 have reported solubilities for the $\mathrm{NH}_{4}^{+}, \mathrm{K}^{+}$, $\mathrm{Rb}^{+}$, and $\mathrm{Cs}^{+}$salts of $\mathrm{TcCl}_{6}^{2-}$ and $\mathrm{TCBr}_{6}^{2-}$ in solutions of their corresponding hydrohalic acids. Solubilities depended little on the acid concentrations, and were fairly small $\left(10^{-2}\right.$ to $\left.10^{-4} \mathrm{~mol} / \mathrm{kg}\right)$. Boyd cited $333 \pm 4 \mathrm{~J} / \mathrm{mol}-\mathrm{K}$ as the entropy of $\mathrm{K}_{2} \operatorname{TcCl}_{6}(\mathrm{c})$ but gave no details.

\section{Other Halotechnetate Salts}

Edwards et $a 1.123$ and Hulgill and Peacock ${ }^{124}$ have reported alkali metal compounda $\mathrm{MTCF}_{6}(\mathrm{c})$, which contain pentavalent technetium. Likewise the hydrazine compound $\mathrm{N}_{2} \mathrm{H}_{6}\left(\mathrm{TcF}_{6}\right)_{2}$, containing $\mathrm{Tc}(\mathrm{V})$, can be formed in anhydrous $\mathrm{HF}, 119$ However, it decomposes at room temperature and it in moisture senaitive. Vinogradov et al. reported that thermal decomposition of $\mathrm{K}_{2} \mathrm{TcI}_{6}$ produced $\mathrm{K}_{2} \mathrm{TcI}_{3} \cdot{ }^{32}$ This material diaproportionatea in aqueous base. None of these compounds are atable in aqueous oolution.

\section{Solid Octahaloditechnetate Salts}

In 1963 Eakins et al. ${ }^{125}$ reported preparing salts of the $\mathrm{Tc}_{2} \mathrm{Cl}_{8}^{3-}$ anion. They can be prepared by the reduction of $\mathrm{TcCl}_{6}^{2-}$ salts in concentrated aqueous HCl using reducing agents such as $\mathrm{H}_{2}$ or $\mathrm{Zn}$. These mixed valence technetium salts have been studied by a number of workers.

Salts of this type that have been reported are

$\left(\mathrm{NH}_{4}\right)_{3}\left[\mathrm{Tc}_{2} \mathrm{Cl}_{8}\right] \cdot 2 \mathrm{H}_{2} \mathrm{O},{ }^{125-127} \mathrm{~K}_{3}\left[\mathrm{Tc}_{2} \mathrm{Cl}_{8}\right] \cdot 2 \mathrm{H}_{2} \mathrm{O}, 125,128$

$\mathrm{Ca}_{3}\left[\mathrm{Tc}_{2} \mathrm{Cl}_{8}\right] \cdot 2 \mathrm{H}_{2} \mathrm{O},{ }^{121} \mathrm{Y}\left[\mathrm{Tc}_{2} \mathrm{Cl}_{8}\right] \cdot 9 \mathrm{H}_{2} \mathrm{O}, 125,129$

$(\mathrm{PyH})_{3}\left[\mathrm{Tc}_{2} \mathrm{Cl}_{8}\right] \cdot 2 \mathrm{H}_{2} \mathrm{O},{ }^{130}(\mathrm{QuinH})_{3}\left[\mathrm{Tc}_{2} \mathrm{Cl}_{8}\right] \cdot 2 \mathrm{H}_{2} \mathrm{O}, 131$ and

$(\mathrm{TBA})_{3}\left[\mathrm{Tc}_{2} \mathrm{Cl}_{8}\right] .^{132}$ Here Py represents pyridine, Quin represents

quinoline, and TBA represents tetrabutyl ammonium groups. Molecular orbital calcialations have been reported for the $\mathrm{Tc}_{2} \mathrm{Cl}_{8}^{3-}$ ion. ${ }^{133-135}$ Koz'min and Novitakaya ${ }^{136} \mathrm{claim}$ to have prepared the compound $\mathrm{K}_{8}\left[\mathrm{Tc}_{2} \mathrm{Cl}_{8}\right]_{3} \cdot\left(\mathrm{H}_{3} \mathrm{O}\right) \cdot 3 \mathrm{H}_{2} \mathrm{O}$ and report its cryatal structure, but evidence for it is not very strong.

Spitsyn et al. ${ }^{80}$ claimed that $\mathrm{Tc}_{2} \mathrm{Cl}_{8}^{3-}$ hydrolyzes without oxidation or reduction to form the mixed valence oxide $\mathrm{Tc}_{4} \mathrm{O}_{5} \cdot \mathrm{mH}_{2} \mathrm{O}$. Oblova et al. 137 studied the thermal decomposition of $\mathrm{K}_{3}\left[\mathrm{Tc}_{2} \mathrm{Cl}_{8}\right] \cdot 2 \mathrm{H}_{2} \mathrm{O}$ in argon. Anhydrous $\mathrm{K}_{3}\left[\mathrm{Tc}_{2} \mathrm{Cl}_{8}\right]$ was formed initially, followed by decomposition to $\mathrm{K}_{2} \mathrm{TcCl}_{6}, \mathrm{KCl}$, and metallic Tc. 
Schwochau et al. ${ }^{138}$ reported that reduction of $\mathrm{TcO}_{4}^{-}$in aqueous $\mathrm{HCl}$ using $\mathrm{H}_{3} \mathrm{PO}_{2}$ gave the TBA salt of $\mathrm{Tc}_{2} \mathrm{Cl}_{8}^{2-}$ with both $\mathrm{Tc}$ atoms in the +3 state. Preetz and Peter ${ }^{132}$ reduced $\mathrm{TcCl}_{6}^{2-}$ with $\mathrm{Zn}$ in concentrated HCl and obtained a mixture of $(\mathrm{TBA})_{2}\left[\mathrm{Tc}_{2} \mathrm{Cl}_{8}\right]$ and $(\mathrm{TBA})_{3}\left[\mathrm{Tc}_{2} \mathrm{Cl}_{8}\right]$ which were extracted with ether. The red bromo analogue $\left(\mathrm{TBA}_{2}\left[\mathrm{Tc}_{2} \mathrm{Br}_{8}\right]\right.$ was also reported. They characterized their alts by elemental analyses, IR, Raman, and absorption spectra.

Recently, Kryuchkov et al. ${ }^{139}$ prepared a number of Tc(II) aalts of $\mathrm{NH}_{4}^{+}$ and $\mathrm{K}^{+}$by 30 atm $\mathrm{H}_{2}$ reduction of Tc salts in concentrated hydrohalic acic

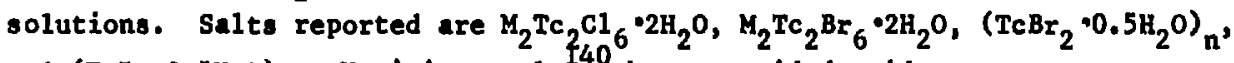
and $\left(\mathrm{TcI}_{2} \cdot 0.5 \mathrm{H}_{2} \mathrm{O}\right)_{\mathrm{n}}$. Koz'min et a1. ${ }^{140}$ have provided evidence for the complex salt $\left[\mathrm{Tc}_{8} \mathrm{Br}{ }_{12}\right] \mathrm{Br}\left[\left(\mathrm{H}_{2} \mathrm{O}\right)_{2} \mathrm{H}\right]$.

\section{Anhydrous Oxyhalides}

Canterford and Colton ${ }^{24}$ list the known oxychlorides of $\mathrm{Tc}$ as $\mathrm{TCO}_{3} \mathrm{Cl}$, $\mathrm{TcOCl}_{4}$, and $\mathrm{TcOCl}_{3}$. The latter two compounds are the products of direct chlorination of $\mathrm{TcO}_{2}(\mathrm{c})$, with the trichloride being the major product. 141 Identification of $\mathrm{TCOCl}_{4}$ was tentative. They readily hydrolyze in $\mathrm{H}_{2} \mathrm{O}$. Rudolph and Bächmann ${ }^{103}$ found evidence for $\mathrm{TcOCl}_{3}$ and $\mathrm{TcOCl}_{4}$ from their high-temperature gas-chromatographic study. Their presence was inferred by analogy to other metals, but no direct evidence was obtained. Spectroscopic data have been reported for $\mathrm{TcOCl}_{3}$, but $\mathrm{TcOCl}_{4}$ was too unstable to permit IR measurement s. 142

$\mathrm{TcO}_{3} \mathrm{Cl}$ can be prepared by the reaction of $\mathrm{O}_{2}$ with $\mathrm{TcCl}_{4}$. Spectroscopic data have been reported for $\mathrm{TcO}_{3} \mathrm{Cl}$ in the gaseous, liquid, and solid states. 143-145 These allow the calculation of thermodynamic functions for $\mathrm{TcO}_{3} \mathrm{Cl}$ vapor from statistical thermodynamic methods. Baran ${ }^{146}$ has performed these calculations and obtained $80.46 \mathrm{~J} / \mathrm{mol}-\mathrm{K}$ for the heat capacity and $317.6 \mathrm{~J} / \mathrm{mol}-\mathrm{K}$ for the entropy. It is also claimed that $\mathrm{TcO}_{3} \mathrm{Cl}$ forms when $\mathrm{Tc}_{2} \mathrm{O}_{7}$ dissolves in concentrated $\mathrm{H}_{2} \mathrm{SO}_{4}$ in the presence of chloride ions. $147 \mathrm{TcO}_{3} \mathrm{Cl}$ hydrolyzes in basic solution to form $\mathrm{TcO}_{4}^{-}$.

Direct bromination of $\mathrm{TcO}_{2}(\mathrm{c})$ yields the oxybromide $\mathrm{TcOBr}_{3}, 141,142$ as does the reaction of $\mathrm{Br}_{2}$ with pertechnetate salts. 141 IR spectra have been reported. 142 This compound has been studied very little. 
A number of technetiun oxyfluorides have been reported, aninly by reduction of $\mathrm{TcO}_{4}^{-}$by anhydrou HP. Compounds reported are: $\mathrm{TCO}_{3}, 7,24 \mathrm{TcO}_{4}, 7,24$ $\mathrm{Tc}_{2} \mathrm{O}_{5} \mathrm{~F}_{4}, 56$ and $\mathrm{TcO}_{2} \mathrm{~F}_{3} \cdot 56$ identification of the last two oxyfluorides is tentative. $\mathrm{TCOF}_{4}$ existe in at least two crystal modifications: a netasable, green trimeric form and a stable b,1ue monomer, $148 \mathrm{TcO}_{3}$ can also be prepared by direct fluorination of $\mathrm{TcO}_{2} \cdot 149$

$\mathrm{TCO}_{3} \mathrm{~F}$ is the nost thoroughly studied oxyfluoride. It spectroscopic properties have been reported for vapor and 1 iquid. 149,150 Vapor preseure measuremente have 1 so been reported for solid and liquid $\mathrm{TCO}_{3} \mathrm{~F}$. 151 These data yield a welting point of $291.5 \mathrm{~K}$, an approxinate boilins point of $373 \mathrm{~K}$, an enthalpy of subliantion of $62.0 \mathrm{~kJ} / \mathrm{mol}$, an enthalpy of fusion of $22.5 \mathrm{KJ} / \mathrm{mol}$, and an enthalpy of vaporization of $39.5 \mathrm{~kJ} / \mathrm{mol}$.

Peacock ${ }^{7}$ has cited unpublished vapor pressure measurenents of A. J. Edwarde for both TcOF 4 solid modifications and for the liquid. These data yield the solid-solid transition point at $357.7 \mathrm{~K}$, a melting point of $406 \mathrm{~K}$, and a boiling point of $438 \mathrm{R}$. The enthalpy change for subliantion of the low tenperature solid is $106.3 \mathrm{~kJ} / \mathrm{mol}$, for sublimation of the high-temperature fusion of the high-temperature $\operatorname{colid} 28.0 \mathrm{~kJ} / \mathrm{mol}$, and $48.5 \mathrm{~kJ} / \mathrm{mol}$ for vaporization. Unfortunately, no enthalpy or free energy of formation data have been published for the coupound.

\section{Solid Tc(v) Oxyhalide Salta}

It is known that pertechnetate salis added to concentrated hydrochloric or hydrobromic acid react fairly rapidly to produce $\mathrm{Tc}(\mathrm{V})$ complex ions, but if the reaction is allowed to continue or the solution warmed, $\operatorname{Tcx}_{6}^{2-}$ ions are produced. Since salts of the Tc(V) complex ions can be isolated, they provide evidence for this species being present in solution.

Reaction of pertechnetate salts with 11 to 12 molar HCl produces $\mathrm{Tc}(V)$ ions, but at lower HCl concentrations addition of $\mathrm{H}_{3} \mathrm{PO}_{2}$ may be required for the reaction to occur at a ressonable rate. Busey reported this reaction but did not isolate any salts. 152,153

Jezowska-Trzebiatowska and coworkers ${ }^{154-156}$ prepared solid salts of the generai type $\mathrm{M}_{2}$ [ $\left.\mathrm{TcOCl}_{5}\right]$ by direct reduction of $\mathrm{TcO}_{4}^{-}$ions with concentrated HCl. The $\mathrm{K}^{+}, \mathrm{Cs}^{+}$, and $\mathrm{MH}_{4}^{+}$salts have been characterized by various spectroscopic wethods and by elenental anelyses. 154-158

Other workers have prepared slightly different salts of the type $\mathrm{M}\left[\mathrm{TCOCl}_{4}\right] .153,159$ Like $\mathrm{K}_{2}\left[\mathrm{TcOCl}_{5}\right]$ ealta, they can be considered 
double alts of the oxychloride $\mathrm{TCOCl}_{3}$. Salte of the type M[TcOCl$\left.{ }_{4}\right]$ fore where the cation ia $\mathrm{TBA}^{+},\left(\mathrm{n}-\mathrm{C}_{4} \mathrm{H}_{9}\right)_{4} \mathrm{x}^{+}$, or $\left(\mathrm{Ph}_{3} \mathrm{P}\right)_{2} \mathrm{x}^{+}$, where

$\mathrm{TBA}^{+}$represents the tetrabutyl amiu cation and

Ph represents the phenyì sroup. Since these two types of salts are produced under nearly identical conditions, cation size way determine wich type forms. That is, amall cations favor $\mathrm{M}_{2}\left[\mathrm{TcOCl}_{5}\right]$ whereas large cations produce $\mathrm{H}\left[\mathrm{TCOCl}_{4}\right]$. Derivatives of $\mathrm{TC}(\mathrm{v})$ oxychlorides with organic ligande are al so known. 160

Anelogous bromide salt: $\mathrm{Ce}_{2}\left[\mathrm{TCOB}_{5} \mathrm{~J}\right.$ and $\mathrm{TBA}\left[\mathrm{TCOBr}_{4}\right]$ are produced by the swe exthod. $157,159,161$ Ligand exchange of M[TCOC1 ${ }_{4}$ ] alta with Isalt: is the favored wthod to produce $M\left[\operatorname{TcOI}_{4}\right], 161,162$ Although direct reaction of $\mathrm{HI}$ with $\mathrm{TcO}_{4}^{-}$al wo worke, reduction to $\mathrm{TCI}_{6}^{2-}$ is usually nush too rapid to allow $\mathrm{TcOr}_{4}^{-}$salt to be isolated. Wo thermodynanic data have been reported for any of these $\mathrm{Ic}(\mathrm{V})$ oxyhalide salts. However, they are all thermodynamically unstable with regard to hydrolyais and dieproportionation to form $\mathrm{TcO}_{2} \cdot 2 \mathrm{H}_{2} \mathrm{O}$ ard $\mathrm{TcO}_{4}^{-}$(aq) in $\mathrm{H}_{2} \mathrm{O}, 161$ and to form $\mathrm{TcX}_{6}^{2-}$ in concentrated hydrohalic acid solutions. 154

These oxyhalides can be isolated a solid conpounds owing to their low reduction kinetice to Tc(IV) in aqueous solution. Partial hydrolyeis of $\mathrm{K}_{2} \mathrm{TcOCl}_{5}(\mathrm{c})$ was reported to form $\mathrm{K}_{2} \mathrm{TcO}(\mathrm{OH}) \mathrm{Cl}_{4}$, but it was difficult to achieve exact stoishionetry. 158

\section{Solid Tc(IV) and Tc(VI) Oxyhalide Salts}

Ziolkowsi et al. showed that tracer amounis of $\mathrm{Tc}$ (IV) could be incorporated into $\mathrm{K}_{4}\left[\mathrm{Re}_{2} \mathrm{OCl} \mathrm{l}_{10}\right] .^{163}$ since wany quadrivalent tranaition metals ( $R u_{v} W$, etc،) form similar compounde, it is reasonable to aenure $\mathrm{Ic}$ (IV) can also. However, one compound with the correct enpirical forwala was proved to be $\mathrm{K}_{2} \mathrm{Tc}(\mathrm{OH}) \mathrm{Cl}_{5}$ by cryotal tructure determination ${ }^{112}$ [i.e. it is not $\left.1 / 2 \mathrm{~K}_{4}\left(\mathrm{Tc}_{2} \mathrm{O}^{\sim} 1_{10}{ }^{\circ \mathrm{H}_{2}} \mathrm{O}\right)\right]$, and it is isostructural with $\mathrm{K}_{2} \operatorname{TcCl}_{6} \cdot$ Being isostructural indicates that of $^{-}$randomly replaces $\mathrm{Cl}^{-}$within the salt. 112 Fergusson et al. 157 recently described the preparation of $\mathrm{H}_{2} \mathrm{Tc}(\mathrm{OH}) \mathrm{Cl}_{5}\left(\mathrm{H}^{+} \mathrm{K}^{+}, \mathrm{Rb}^{+}\right.$, Or $\left.\mathrm{Cs}^{+}\right)$and $\mathrm{Cs}_{2}(\mathrm{OH}) \mathrm{Br}_{5}$, from $\mathrm{I}^{-}$ reduction of $\mathrm{TeO}_{4}^{-}$in $\mathrm{HCl}$ and $\mathrm{HBr}$ solutions. 
Colton and Tomins 141 reacted thicnyl chloride (an extrewely atrong Lewis acid) with $\mathrm{NH}_{4} \mathrm{TcO}_{4}$ to prepare the thionyl chloride adduct $\left(\mathrm{NH}_{4}\right)_{2}\left[\mathrm{TCO}_{2} \mathrm{Cl}_{4}\right] \cdot \mathrm{SO}_{2} \mathrm{Cl}_{2}$ which contains $\mathrm{Tc}(\mathrm{VI})$. Several technetium oxychloride complexes with organic ligands are also known. 25

Technetiue Sulfides, Nitrides, Borides, and Carbides

Rulfs and Veinke ${ }^{164}$ found that $\mathrm{H}_{2} \mathrm{~S}$ reduces $\mathrm{TcO}_{4}^{-}$to $\mathrm{Tc}_{2} \mathrm{~S}_{7}$ in HCl solution. Heating this $\mathrm{Tc}_{2} \mathrm{~S}_{7}$ with axces sulfur, followed by sublimation yielde $\operatorname{TeS}_{2}{ }^{3}$ Neither of these cowpounde have publiahed data for $G_{f}^{\circ}$ or $\Delta H_{f}^{0}$. However, McDonald and Cobble ${ }^{165}$ have eatimated $\Delta H_{f}^{0}=-224$ $\mathrm{kJ} / \mathrm{mol}$ for $\mathrm{TCS}_{2},-276 \mathrm{~kJ} / \mathrm{mol}$ for $\mathrm{TCS}_{3}$, and $-615 \mathrm{~kJ} / \mathrm{mol}$ for $\mathrm{Tc}_{2} \mathrm{~S}_{7}$. Their estianted $\Delta G_{f}^{0}$ values are $-216 \mathrm{~kJ} / \mathrm{mol}$ for $\mathrm{TcS}_{2},-263 \mathrm{~kJ} / \mathrm{mol}$ for $\mathrm{TcS}_{3}$, and $-581 \mathrm{~kJ} / \mathrm{mol}$ for $\mathrm{Tc}_{2} \mathrm{~s}_{7}$. Their estimated cntropies are $71 \mathrm{~J} / \mathrm{mol}-\mathrm{K}$ for $\mathrm{TcS}_{2}, 84 \mathrm{~J} / \mathrm{mol} \mathrm{K}$ for $\mathrm{TcS}_{3}$, and $176 \mathrm{~J} /$ mol-K for $\mathrm{Tc}_{2} \mathrm{~S}_{7}$. However, there is no experinental evidence for $\mathrm{TcS}_{3}$.

Table 3 containa reconnended thermodynamic data for the various pure technetiun compounds discussed earlier.

TABLE 3. Recommended data for anhydrous pertechnetates, halides, Jxyhalides, and sulfides at $298 \mathrm{~K}$.

Compound Phase $\quad G_{f}^{\circ}$ in $K J / m o l \quad \Delta H_{f}^{0}$ in $K J / m o l \quad g^{\circ}$ in $J / m o i-K$

$\begin{array}{llccc}\mathrm{KTcO}_{4} & \text { Crystal } & -919.2 \pm 10.0 & -1022.2 \pm 5.5 & 164.78 \\ \mathrm{NaTcO}_{4} & \text { Crystal } & -877.0 \pm 10.1 & - & - \\ \mathrm{HTcO}_{4} & \text { Crystal } & --589.8 \pm 10.5 & -703.8 \pm 9.6 & =126.3 \\ \mathrm{TcF}_{6} & \text { High-T } & & & \\ & \text { crystal } & - & - & 253.52 \pm 0.25 \\ \mathrm{TcF}_{6} & \text { Gas } & - & - & 371.28 \pm 0.75 \\ \mathrm{~K}_{2} \mathrm{TcCl}_{6} & \text { Crystal } & - & - & 333 \pm 4 \\ \mathrm{TcO}_{3} \mathrm{Cl} & \text { Gas } & - & -224 & 317.6 \\ \mathrm{TcS}_{2} & \text { Crystal } & \approx-216 & \approx-276 & \approx 71 \\ \mathrm{TcS}_{3} & \text { Crystal } & \approx-263 & \approx-615 & \approx 4 \\ \mathrm{Te}_{2} S_{7} & \text { Crystal } & \approx-581 & & \approx 176\end{array}$


Thermal decomposition of $\mathrm{NH}_{4} \mathrm{TcO}_{4}$, in the presence of argon, or of $\left(\mathrm{NH}_{4}\right)_{2} \mathrm{TcX}_{6}\left(\mathrm{X}=\mathrm{Cl}^{-} \text {or } \mathrm{Br}^{-}\right)^{166}$ yield material with the approximate composition $\mathrm{TcN}_{0.75}$ or $\mathrm{TcK}_{0.76^{*}}{ }^{29,67}$ Heating $\mathrm{NH}_{4} \mathrm{TcO}_{4}$ in $\mathrm{NH}_{3}$ or argon-ammia mixtures yields a nitride approachirg stoichionetric TcK. 67 Several borides of Tc have also been reported: $\mathrm{Tc}_{3} \mathrm{~B}, \mathrm{Tc}_{7} \mathrm{~B}_{3}, \mathrm{TcB}$, $\mathrm{Tc}_{3} \mathrm{~B}_{4}$, and $\mathrm{TcB}_{2} \cdot{ }^{29}$ None of these conpounds have published $\Delta G_{\mathrm{F}}^{\circ}$ or $\Delta \mathrm{H}_{\mathrm{f}}^{\mathrm{O}}$ data. A bond dissociation energy of $561 \pm 29 \mathrm{KJ} / \mathrm{mol}$ has been reported for $\operatorname{Tcc}(g) .167$

Gommente on Thermodynamic Stability and the Effects of Radiation

Thermodynamic data can be used to calculate the distribution of various compounds and ions of an element at thermodynamic equilibrium. However, in the presence of a significant radiation flux, Tc can undergo reactione not anticipated from thermodynamic considerationa.

For example, Cobble et al. 168 noted that Tc metal is difficult to maintain in the zerovalent (metallic) state in moist air, and Cartledge' 8 study indicates that radiation probably participates in some of the reactions involving hydrous oxides/hydroxides on a metallic Tc surface. Tc atome can be ionized by radiation and, in that state, are more prone to oxidation.

Under certain conditions radiation fluxes will increase the likelihood of oxidation. For example, Ferradini et al. ${ }^{169}$ found that B decay of ${ }^{99} \mathrm{Mo}$ in $\mathrm{H}_{2} \mathrm{O}$ produces mainly ${ }^{99} \mathrm{TcO}_{4}^{-}$both in the presence and absence of air (even when the parent ${ }^{99}$ Mo was originally in the +4 state). Lefort ${ }^{73}$ found that $\gamma$-radiolysis caused aqueous $\mathrm{TcO}_{2} \mathrm{mH}_{2} \mathrm{O}$ to be oxidized predominantly to $\mathrm{TcO}_{4}^{-}$. Cifka and $\mathrm{Vesely^{170 }}$ found $\mathrm{Tc}(\mathrm{IV})$ was unstable in neutral solutions, and was oxidized to $\mathrm{TcO}_{4}^{-}$by $\gamma$-radiolysis. They also found that once $\mathrm{O}_{2}$ is depleted, then radiolysis caused Tc to be reduced rather than oxidized.

Ianovici et al. ${ }^{171-173}$ have done several atudies with $95 \mathrm{~m}_{\mathrm{Tc}}$. The internal conversion $95 \mathrm{~m}_{\mathrm{Tc}}+95 \mathrm{~g}_{\mathrm{Tc}}$ for $\mathrm{TcO}_{4}^{-}$in solution had chemical effects that depended on $\mathrm{pH}$. At $\mathrm{pH}=0.1$ or 8 , about $86 \%$ of the Tc remuined as $\mathrm{TcO}_{4}^{-}$whereas the rest was reduced. However, the amount of $\mathrm{TcO}_{4}^{-}$ remaining decreased to $35 \%$ at $\mathrm{pH}=3.173$ 
Internal conversion of ${ }^{95 \mathrm{~m}} \mathrm{Tc}$ in the compounds $\left(\mathrm{NH}_{4}\right)_{2} \mathrm{TcCl}_{6}(\mathrm{c})$ or $\mathrm{K}_{2} \mathrm{TcCl}_{6}(\mathrm{c})$ produced little oxidation and only a few percent of $\mathrm{TcO}_{4}^{-}$ wrs found upon dissolution. 171,172 Self-radiolysis of these compounds in solution gave more extensive oxidation. 172

$Z F$ the radiation $f l u x$ is reduced, then these systems should gradually return to thermodynamic equilibrium. However, thermodynamic calculations should be done with caution when this is not the case (e.g. concentrated nuclear reactor wastes).

DATA FOR AQUEOUS SOLUTIONS

\section{Genera1 Comments}

A large number of studies of the aqueous electrochemistry of Tc have been reported. These include acidic, basic, and neutral solutions, and in both noncomiexing and complexing media. Such varied techniques as polarography, radiopolarography, cyclic voltametry, coulometry, ald chronoamperometry have been applied. However, our understanding of these systems is far from complete. Several recent reviews summarize these data and illustrate the numerous conflicting claims in the literature. $20,147,174-177$

There are a number of reasons why the interpretation of this electrochemiatry is so difficult. Nearly all of the electrochemical redox couples of Tc in noncomplexing and chloride containing solutions are thermodynamically irreversible, which makes it very difficult to extract meaningful thermodynamic data. Also, while some redox reactions are reversible in complexing media, the nature of the oxidized and reduced species involved usually are not known. Catalytic discharge of hydrogen sometimes interferes with the measurements, for example, when

$$
\mathrm{Tc}^{3+}(\mathrm{aq})+3 \mathrm{e}^{-}=\mathrm{Tc}^{\mathrm{o}}(\mathrm{c})
$$

is being studied in acidic solutions. In addition $\mathrm{Hg}(1)$, which is used as an electrode for most polarographic measurements, reduces $\mathrm{TcO}_{4}^{-}$to lower valence species in acidic media. Because of these and other problems, electrochemical data must be used with caution. These problems will be discussed in more detail later. 
Aqueous Pertechnetates and HTć,

The one case where unambiguous and accurate data exiat in aqueous solution is for $\mathrm{TcO}_{4}^{-}$salts. This is because data are available both for $\mathrm{Tc}_{2} \mathrm{O}_{7}(\mathrm{c})$ and $\mathrm{KTcO}_{4}(\mathrm{c})$, and for the thermodynamics of their dissolution in $\mathrm{H}_{2} \mathrm{O}$.

$$
\begin{aligned}
& \mathrm{Tc}_{2} \mathrm{O}_{7}(\mathrm{c}) \text { diseolves in water according to the reaction } \\
& \mathrm{Tc}_{2} \mathrm{O}_{7}+\mathrm{H}_{2} \mathrm{O}=2 \mathrm{TcO}_{4}^{-}(\mathrm{aq})+2 \mathrm{H}^{+}
\end{aligned}
$$

to form pertechnetic acid. Its ionization constant is about $10^{9}$, so it is as atrong an acid as $\mathrm{HBr} .147$ Isopiestic activity measuremente have been made for $\mathrm{HTcO}_{4}$ solutiona from 0.106 to $5.440 \mathrm{~mol} / \mathrm{kg}$. 178

$\mathrm{Tc}_{2} \mathrm{O}_{7}(\mathrm{c})$ is yellow and dilute solutions of $\mathrm{HTCO}_{4}(\mathrm{aq})$ are colorless. However, by about $5 \mathrm{~mol} / \mathrm{kg}, \mathrm{HTCO}_{4}$ solutions are pink and the color darkens to red at higher concentrations. This red color is usually assured to be due to $\mathrm{HTCO}_{4}$, but Rulfs et $\mathrm{al} \cdot 147$ provided evidence that the color could be due to small amounts of $\mathrm{TcO}_{4}^{2-}$ or $\mathrm{TcO}_{4}^{3-}$, which are produced by the reduction of $\mathrm{TcO}_{4}^{-}$by $\mathrm{H}_{2} \mathrm{O}$ or by dust particles in very acid solutions.

The aqueous $\mathrm{TcO}_{4}^{-}$ion is tetrahedral with small perturbations due to close association with water molecules. ${ }^{179}$ Rulfs et al. ${ }^{147}$ found no evidence that $\mathrm{TcO}_{4}^{-}$aggregates to form dimers or higher order clusters in $1 \mathrm{~mol} / 1$ acid or base. Properties of cryatalline $\mathrm{TcO}_{4}^{-}$salts were discussed above.

Schwochau and Astheimer ${ }^{180}$ measured the electrical conductivity of aqueous $\mathrm{KTcO}_{4}$ at $298 \mathrm{~K}$ and obtained a limiting ionic conductance for $\mathrm{TcO}_{4}^{-}$(aq) of $.55 .5 \pm 0.5 \mathrm{~cm}^{2} / 0 h m-e q u i v$. This yields a tracer diffusion coefficient of $(1.48 \pm 0.01) \times 10^{-5} \mathrm{~cm}^{2} / \mathrm{s}$ at $298 \mathrm{~K}$. A more approximate ionic conductance of $47.2 \pm 3.0 \mathrm{~cm}^{2} / \mathrm{ohm}$-equiv, at $291 \mathrm{~K}$ was obtained using electrophoresis. 191 These data are important since diffusio I coefficients sometimes help in interpreting polarographic measurements.

Shvedov and Kotegov ${ }^{181}$ used their electrophoresis measurements to 
calculate dissociation constants for pertechnetate ion pairs in aqueous solution

$$
\mathrm{MTcO}_{4}(\mathrm{aq})=\mathrm{M}^{+}(\mathrm{aq})+\mathrm{TcO}_{4}^{-}(\mathrm{aq})
$$

They obtained $\mathrm{K}_{\mathrm{diss}}=0.122 \pm 0.004 \mathrm{~mol} / 1$ for $\mathrm{KTcO}_{4}$ and $\mathrm{K}_{\mathrm{diss}}=0.23$

$\pm 0.03 \mathrm{~mol} / 1$ for $\mathrm{CsTcO}_{4^{\circ}}$. Estimated activity coefficients were used so these are "thermodynamic constants." It is difficult to judge the accuracy of such calculated values, but the method did work fairly we11 (5\%) for acetic acid. They claim agreement with a "theoretical value" from Cobble et al. for $\mathrm{KTcO}_{4}, 62$ but Cobble et a1. actually gave a solubility product and not $k_{d i s s}$ o the agreement in numerical values was fortuitoua.

As was mentioned above, Busey et $21 . a^{64}$ heat capacity data for $\mathrm{KTcO}_{4}(\mathrm{c})$ yield s $\mathrm{s}^{\mathrm{O}}\left[\mathrm{KTcO}_{4}(\mathrm{c})\right]=164.78 \mathrm{~J} / \mathrm{mol}-\mathrm{K}$. They also give the entropy of solution of $\mathrm{KTCO}_{4}(\mathrm{c})$ as $\Delta \mathrm{S}_{801}^{\mathrm{O}}=135.3 \pm 1.3 \mathrm{~J} / \mathrm{mol}-\mathrm{K}$ based on solubilities as a function of temperature. The "absolute" entropy of aqueous $\mathrm{KTcO}_{4}$ is then

$s^{0}\left[\mathrm{KTcO}_{4}(\mathrm{aq})\right]=\mathrm{s}^{\mathrm{O}}\left[\mathrm{KTcO}_{4}(\mathrm{c})\right]+\Delta \mathrm{S}_{\mathrm{sol}}=300.1 \pm 1.3 \mathrm{~J} / \mathrm{mol}-\mathrm{K}$

at $298 \mathrm{k}$. Subtracting the ionic entropy of $\mathrm{K}^{+}$(CODATA) gives $\mathrm{s}^{0}\left[\mathrm{TcO}_{4}^{-}(\mathrm{aq})\right]=199.0 \pm 1.3 \mathrm{~kJ} / \mathrm{mol}$.

Cobble et al. 62 determined the enthalpy of formation of $\mathrm{Tc}_{2} \mathrm{O}_{7}(\mathrm{c})$ to be $-1113.4 \pm 10.9 \mathrm{~kJ} / \mathrm{mol}$. Their enthalpy of solution for

$$
\mathrm{Tc}_{2} \mathrm{O}_{7}(\mathrm{c})+\mathrm{H}_{2} \mathrm{O}(1)=2 \mathrm{HTcO}_{4}(\mathrm{aq})
$$

is $-48.49 \pm 0.33 \mathrm{~kJ} / \mathrm{mol}$. The enthalpy of formation of aqueous $\mathrm{HTCO}_{4} \mathrm{can}$ be obtained from the reaction

$$
2 \mathrm{Tc}(\mathrm{c})+7 / 2 \mathrm{O}_{2}(\mathrm{~g})+\mathrm{H}_{2} \mathrm{O}(1)=2 \mathrm{HTcO}_{4}(\mathrm{aq}),
$$

80

$\Delta H_{\mathrm{rXn}}^{o}=2 \Delta \mathrm{H}_{\mathrm{f}}^{0}\left[\mathrm{HTcO}_{4}(\mathrm{aq})\right]-2 \Delta \mathrm{H}_{\mathrm{f}}^{0}[\mathrm{Tc}(\mathrm{c})]-7 /: \Delta \mathrm{H}_{\mathrm{f}}^{0}\left[\mathrm{O}_{2}(g)\right]-\Delta \mathrm{H}_{\mathrm{f}}^{0}\left[\mathrm{H}_{2} \mathrm{O}(1)\right]$,

where $\Delta \mathrm{H}_{\mathrm{rXn}}^{\mathrm{o}}[\mathrm{Tc}(\mathrm{c})]=\Delta \mathrm{H}_{\mathrm{f}}^{\mathrm{o}}\left[\mathrm{O}_{2}(\mathrm{~g})\right]=0$ by definition. Thus, 
$\Delta \mathrm{H}_{\mathrm{rxn}}^{\mathrm{O}}=2 \Delta \mathrm{H}_{\mathrm{f}}^{\mathrm{O}}\left[\mathrm{HTcO}{ }_{4}(\mathrm{aq})\right]-\Delta \mathrm{H}_{\mathrm{f}}^{\circ}\left[\mathrm{H}_{2} \mathrm{O}(1)\right]$

and $\Delta \mathrm{H}_{\mathrm{f}}^{\circ}\left[\mathrm{H}_{2} \mathrm{O}(1)\right]=-264.91 \mathrm{~kJ} / \mathrm{mol}$ from CODATA. However, it is also true that $\Delta \mathrm{H}_{\mathrm{Txn}}^{\mathrm{O}}=\Delta \mathrm{H}_{\mathrm{f}}^{\mathrm{O}}\left[\mathrm{Tc}_{2} \mathrm{O}_{7}(\mathrm{c})\right]+\Delta \mathrm{H}_{\mathrm{Ho1}}^{\mathrm{O}}$,

so $\mathrm{dH}_{\mathrm{rxn}}^{\mathrm{O}}=-1161.9 \pm 11.2 \mathrm{KJ} / \mathrm{mol}$, and

$\Delta \mathrm{H}_{\mathrm{f}}^{\mathrm{O}}\left[\mathrm{HTCO}_{4}(\mathrm{eq})\right]=1 / 2\left\{\Delta \mathrm{H}_{\mathrm{rxn}}^{\mathrm{O}}+\Delta \mathrm{H}_{\mathrm{f}}^{\circ}\left[\mathrm{H}_{2} \mathrm{O}(1)\right]\right\}=-713.4 \pm 5.6 \mathrm{~kJ} / \mathrm{mol}$.

Independent data by Gayer et $1 .{ }^{63}$ gives $\Delta \mathrm{H}_{\mathrm{sol}}^{\circ}=-45.6 \pm 1.3 \mathrm{~kJ} / \mathrm{mol}$ and

$\Delta \mathrm{H}_{\mathrm{f}}^{\mathrm{O}}\left[\mathrm{Tc}_{2} \mathrm{O}_{7}(\mathrm{c})\right]=-\mathrm{i} 127.6 \pm 7.9 \mathrm{~kJ} / \mathrm{mol}$. For these data, $\Delta \mathrm{H}_{\mathrm{rXn}}^{\mathrm{O}}$

$=-1173.2 \pm 8.0 \mathrm{~kJ} / \mathrm{mol}$ and $\Delta \mathrm{H}_{\mathrm{f}}^{\circ}\left[\mathrm{HTCO}_{4}(\mathrm{aq})\right]=-719.1 \pm 4.0 \mathrm{~kJ} / \mathrm{mol}$.

For a standard-state thermodynamic-value additivity applies. That is,

$\Delta \mathrm{H}_{\mathrm{f}}^{\mathrm{O}}\left[\mathrm{HTcO}_{4}(\mathrm{aq})\right]=\Delta \mathrm{H}_{\mathrm{f}}^{\mathrm{O}}\left[\mathrm{H}^{+}(\mathrm{aq})\right]+\Delta \mathrm{H}_{\mathrm{f}}^{\mathrm{O}}\left[\mathrm{TcO}_{4}^{-}(\mathrm{aq})\right]=\Delta \mathrm{H}_{\mathrm{f}}^{\mathrm{O}}\left[\mathrm{TcO}_{4}^{-}(\mathrm{aq})\right]$

since $\Delta \mathrm{H}_{\mathrm{f}}^{0}\left[\mathrm{H}^{+}(\mathrm{aq})\right]=\mathrm{O}$ by convention. The average of

$\Delta \mathrm{H}_{\mathrm{f}}^{\mathrm{O}}\left[\mathrm{TcO}_{4}^{-}(\mathrm{aq})\right]=-716.3 \pm 4.5 \mathrm{~kJ} / \mathrm{mol}$ is accepted as the best value.

To calculate $\Delta G_{f}^{\circ}\left[\mathrm{TcO}_{4}^{-}(\mathrm{aq})\right]$ requires $\Delta \mathrm{H}_{\mathrm{f}}^{\mathrm{O}}$ and $\Delta \mathrm{S}_{\mathrm{f}}^{\mathrm{O}}$ values.

The $\Delta S_{f}^{0}$ for $\mathrm{TcO}_{4}^{-}(a q)$ can be calculated from

$s^{\circ}\left[\mathrm{TcO}_{4}^{-}(\mathrm{aq})\right]=\Delta s_{\mathrm{f}}^{\mathrm{o}}\left[\mathrm{TcO}_{4}^{-}(\mathrm{aq})\right]+s^{\circ}[\mathrm{Tc}(\mathrm{c})]+2 s^{\circ}\left[\mathrm{O}_{2}(\mathrm{~g})\right]+s^{\circ}\left(\mathrm{e}^{-}\right)$,

where $s^{\circ}\left(e^{-}\right)=65.29 \mathrm{~J} / \mathrm{mol}-\mathrm{K}$ is the hydrogen value and is required to maintain

consistency with the hydrogen-ion convention. Thus, $\Delta \mathrm{S}_{\mathrm{f}}^{\circ}\left[\mathrm{TcO}_{4}^{-}(\mathrm{aq})\right]$

$=-309.7 \pm 2.5 \mathrm{~J} / \mathrm{mol}-\mathrm{K}$ and

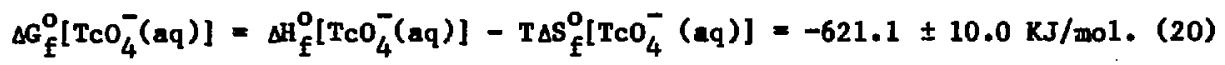


Aqueous $\mathrm{TcO}_{4}^{2-}, \mathrm{HTcO}_{4}^{-}$, and $\mathrm{H}_{2} \mathrm{TcO}_{4}$

Most studies of the reduction of $\mathrm{TcC}_{4}^{-}$in aqueous solutions indicate a $2 \mathrm{e}^{-}$or $3 \mathrm{e}^{-}$reduction to form a $\mathrm{Tc}(\mathrm{V})$ or Tc(IV) species. Under sone conditions a $1 \mathrm{e}^{-}$reduction occurs to form $\mathrm{Tc}(\mathrm{VI})$, which is unstable and rapidly disproportionates. The mode of reduction and decomposition usually suggested for alkaline solutions ${ }^{182}$ is

$$
\begin{aligned}
& \mathrm{TcO}_{4}^{-}+e^{-}=\mathrm{TcO}_{4}^{2-} \\
& 2 \mathrm{TcO}_{4}^{2-}=\mathrm{TcO}_{4}^{-}+\mathrm{TcO}_{4}^{3-}
\end{aligned}
$$

and $\mathrm{TCO}_{4}^{3-}$ is also unstable. However, other variants for the alkaline solution disproportionation of $\mathrm{TcO}_{4}^{2-}$ include 183

$$
3 \mathrm{TcO}_{4}^{2-}+\mathrm{H}_{2} \mathrm{O}=2 \mathrm{TcO}_{4}^{-}+\mathrm{TcO}_{3}^{2-}+2 \mathrm{OH}^{-}
$$

Somewhat different reactions have been proposed for acidic solutions. One claim is that reduction in acidic solutions follows the mechanism ${ }^{184}$

$$
\begin{aligned}
& \mathrm{TcO}_{4}^{-}+2 \mathrm{H}^{+}+\mathrm{e}^{-}=\mathrm{TcO}_{3}+\mathrm{H}_{2} \mathrm{O} \\
& \mathrm{TcO}_{3}+\mathrm{e}^{-}=\mathrm{TcO}_{3}^{-} \\
& \mathrm{TcO}_{3}^{-}+3 \mathrm{H}^{+}+2 \mathrm{e}^{-}=\mathrm{TcO}(\mathrm{OH})+\mathrm{H}_{2} \mathrm{O} .
\end{aligned}
$$

An alternate claim for acidic solutions is the disproportionation mechanism 185

$$
\begin{aligned}
& 2 T_{c}(V I)=T_{c}(V I I)+T c(V) \\
& 2 T_{c}(V)=T c(V I)+T c(I V) .
\end{aligned}
$$

Here $\mathrm{Tc}(\mathrm{VI})$ could be $\mathrm{TcO}_{4}^{2-}, \mathrm{HTcO}_{4}^{-}$, or $\mathrm{H}_{2} \mathrm{TcO}_{4}, \mathrm{Tc}(\mathrm{VII})$ is $\mathrm{TcO}_{4}^{-}$, and the nature of $\mathrm{Tc}(\mathrm{IV})$ is uncertain. If $\mathrm{TcO}_{4}^{2-}$ were unprotonated, then the first reaction would be identical to the alkaline solution case. There is tio concensus for the reduction mechanisms, and they are probably slightly diffiarent in acidic and basic media. 
The isolation of a crystalline $\mathrm{TcO}_{4}^{2-}$ salt by Astheimer et al. 94 suggeats that the $\mathrm{Tc}(\mathrm{VI})$ aqueors species could be $\mathrm{TcO}_{4}^{2-}$. Their observation that this salt decomposed in moist air is concordant with the instability of $\mathrm{TcO}_{4}^{2-}$ in aqueous solution. Decomposition of this $\mathrm{TcO}_{4}^{2-}$ salt in neutral deaerated $\mathrm{H}_{2} \mathrm{O}$ gave equal amounts of $\mathrm{Tc}$ (VII) and $\mathrm{Tc}(\mathrm{V})$ when the product was analyzed immediately after mixing. 95 This agrees completely with the above mechanisms for disproportionation of Tc (VI) in solution.

Evidence for this same structure for aqueous Tc(VI) is also available from the electrochemical reduction of $\mathrm{TcO}_{4}^{-}$in alkaline solution. Kissel and Feldberg 182 found that the variation of the rate of disproportionation of Tc(VI) with ionic strength confirmed that the Tc(VI) species was doubly charged. Also, in basic solution, reduction of $\mathrm{TcO}_{4}^{-}$with a pulsed electron beara had first order kinetics for both $\mathrm{TcO}_{4}^{-}$and $e^{-}, 186,187$ which implies a $1 \mathrm{e}^{-}$reduction is occurring. In addition, the species produced by electron beam reduction in alkaline solution had an absorption opectra 186,187 very similar to the crystalline $\mathrm{TcO}_{4}^{2-} \mathrm{salt}^{94}$ Tngether, these studies provide convincing evidence that in aqueous alkaline solutions the $\mathrm{Tc}(\mathrm{VI})$ species is present as $\mathrm{TcO}_{4}^{2-}$.

Hurst $^{186}$ and Deutsch et al. 187 noted that the absorption spectra of $\mathrm{TcO}_{4}^{2-}$ in alkaline media, produced by pulsed radiolysis with an electron beam, looked very different from Pikaev et $a 1 .{ }^{\prime} s^{188}$ reaults by the same method in neutral solutions. Pikaev et al. ${ }^{188}$ attributed spectral details to the successive protonation of $\mathrm{TcO}_{4}^{2-}$ to form $\mathrm{HTcO}_{4}^{-}$and $\mathrm{H}_{2} \mathrm{TcO}_{4}$. Their later, ${ }^{185}$ more detailed study confirmed this and provides values for the dissociation constants of this acid.

Pihlar ${ }^{184}$ found that the rate determining step for $\mathrm{TcO}_{4}^{-}$reduction in acidic media was second order in hydrogen ion and suggested that the rate determining step involved

$$
\mathrm{TcO}_{4}^{-}+2 \mathrm{H}^{+}+\mathrm{e}^{-}=\mathrm{TcO}_{3}+\mathrm{H}_{2} \mathrm{O} \text {. }
$$

However, it is known that $\mathrm{TcO}_{4}^{2-}$ protonates to form $\mathrm{HTcO}_{4}^{-}$and $\mathrm{H}_{2} \mathrm{TcO}_{4} \cdot 185,188$ These species could be responsible for the observed rate law, rather than the deoxygenation reaction suggested by Pihlar. 184 We will assume that $\mathrm{TcO}_{3}$ does not form in the following discussion, but this is 
a provisional assumption for very acid solutions. The only case where this distinction is important is in obtaining acid dissociation constants ${ }^{185}$ of $\mathrm{H}_{2} \mathrm{TcO}_{4}$, since $\mathrm{TcO}_{3}$ has no associated protons.

Further support for disproportionation of $\mathrm{Tc}(\mathrm{VI})$ to form $\mathrm{Tc}(\mathrm{V})$ and Tc(VII) cowes from Crouthamel's 189 spectrophotometric study of the chemical reduction of $\mathrm{TcO}_{4}^{-}$in $\mathrm{H}_{2} \mathrm{SO}_{4}$ solution. However, Crouthamel suggested that $T c(V I)$ also rapidly reacts with $T c(I V)$ to produce $\operatorname{Tc}(v)$ :

$$
T c(V I)+T c(I V)=2 T c(V)
$$

with the lower subsequent reaction

$$
3 T c(V)=\operatorname{Tc}(V I I)+2 T c(I V)
$$

This indicates that the decomposition of Tc(VI) in acidic solution may be even more complex than assumed by other workers .

Rulfs et a1. 147 and Majumdar et al. 190 suggested that the red color of concentrated $\mathrm{HTCO}_{4}$ solutions may be due to formation of sone $\mathrm{H}_{2} \mathrm{TcO}_{4}$ by reduction of $\mathrm{HTCO}_{4}$ by $\mathrm{H}_{2} \mathrm{O}$ or dust. A similar color was obtained as an intermediate stage of $\mathrm{TcO}_{4}^{-}$reduction by hydrazine. They originally thought this was due to Tc(VI), ${ }^{147}$ but Iater decided that Tc(V) was more like1y. 190

The $\mathrm{TcO}_{4}^{2-}$ ion is very short lived in aqueous solution under normal conditions. Hurst ${ }^{186}$ and Deutsch et al. ${ }^{187}$ found that in alkaline solutions it had a lifetime of at least $10 \mathrm{~ms}$, but that noticeable reactions occur within 50 Ins. Kissel and Feldberg ${ }^{182}$ studied the decomposition kinetics of $\mathrm{TcO}_{4}^{-}$in 0.001 to $0.10 \mathrm{~mol} / 1 \mathrm{NaOH}$ and found the disproportionation to be slower at higher NaOH concentrations. Kruchkov et al. 185 atudied this decomposition kinetics from about $\mathrm{pH}=-1$ to +12 , and they found the disproportionation rate had a maximum around $\mathrm{pH}-8$ to 9 . The rate decrease above $\mathrm{pH}=9$ agrees with Kissel and Feldberg. 182 The rate of disappearance of $\mathrm{TcO}_{4}^{2-}$ was second order in $\mathrm{TeO}_{4}^{2-},{ }^{185}$ so disproportionation to $\mathrm{Tc}(V)$ and $\mathrm{Tc}(V I I)$ is 1 ikely. 
The disproportionation of $\mathrm{TcO}_{4}^{2-}$ is fairly rapid, so most standard electrochemical techniques do not observe the $\mathrm{le}^{-}$reduction of $\mathrm{TcO}_{4}^{-}$to $\mathrm{TcO}_{4}^{2-}$. Instead a $2 \mathrm{e}^{-}$or $3 \mathrm{e}^{-}$reduction of $\mathrm{TcO}_{4}^{-}$is observed. However, Kissel and Feldberg ${ }^{182}$ found that addition of snall anounts of gelatin $(\times 0.005$ weight $\mathrm{z})$ to alkuline $\mathrm{TcO}_{4}^{-}$kinetically blocks the decomposition of $\mathrm{TcO}_{4}^{2-}$ to $\mathrm{TcO}_{4}^{3-}$, so the speciea $\mathrm{TcO}_{4}^{2-}$ lasts sufficiently long to be characterized electrochemically. By studying the number of electrona involved in the electrochemical reduction of $\mathrm{TcO}_{4}^{-}$ as a function of $\mathrm{kaOH}$ and of gelatin concentratione, they were able to demonatrate a witch from $2 \mathrm{e}^{-}$to $a 1 \mathrm{e}^{-}$reduction mechanism in neutral and besic solutions.

Several studies give values for the reduction potential for

$$
\mathrm{TcO}_{4}^{-}+e^{-}=\mathrm{TcO}_{4}^{2-}
$$

in aqueous basic solution. Most reduction potentials are reported va. the saturated calomel electrode. In this and subsequent sections, all potentials cited were converted (if necessary) to reduction potentials vs. the normal hydrogen electrode (NHE), by using $0.242 \mathrm{~V}$ as the potential of the saturated calomel electrode vs. NHE.

Kissel and $\mathrm{Feldberg}{ }^{182}$ atudied alkaline $\mathrm{TcO}_{4}^{-}$using

chronoamperometric methods. Without gelatin, reduction from $\mathrm{TcO}_{4}^{-}$to $\mathrm{TcO}_{4}^{3-}$ occurs directly. When $0.005 \%$ or more gelatin was added, the mechanism shifts to a $1 \mathrm{e}^{-}$reduction. Their "apparent $\mathrm{n}$ " vs. step potential curves allow the

$$
\mathrm{TcO}_{4}^{-}+\mathrm{e}^{-}=\mathrm{TcO}_{4}^{2-}
$$

quasi-reversible aqueous reduction potential in basic media to be estimated as being $\propto-0.63 \pm 0.05 \mathrm{~V}$ at an ionic strength of $I=1.0$.

A polarographic value of $\approx-0.52 \mathrm{~V}$ was obtained for this reduction potential in a $\mathrm{NaOH}-\mathrm{Na}_{2} \mathrm{SO}_{4}$ solution at $\mathrm{I}=3.0$ (but they may have misidentified the reduction wave), 191 and $x-0.56 \mathrm{v}$ for reduction in buffered alkaline media. 177 Spitsyn et al. ${ }^{192}$ reported $x-0.60 \mathrm{~V}$.

All of the above potential values are known only to one significant figure but do cluster around $-0.6 \mathrm{v}$. A more detailed study of this potential was made by Hurst ${ }^{186}$ and Deutsch et al. 187 using fast-acan cyclic 
voltametry on a hanging-drop mercury electrode. Reduction curves are always present, but under normn1 conditions no reoxidation curve is seen since decomposition of $\mathrm{TcO}_{4}^{2-}$ is too rapid. In $1 \mathrm{~mol}^{2} 1 \mathrm{NH}_{4} \mathrm{OH}$ no reoxidation was observed at any scan rate.

In $\mathrm{HaOH}$ solutions at low scan rates no reoxidation of $\mathrm{TcO}_{4}^{2-}$ is found, but at $100 \mathrm{~V} / \mathrm{s}$ reoxidation is nearly complete in $0.12 \mathrm{~mol} / 1$ aqueous NaOH. ${ }^{186,187}$ In 1 mol/1 $\mathrm{NaOH}^{186}$ similar results are obtained, but results are less clearcut since the $\mathrm{TcO}_{4}^{2-}$ decomposition rate also seems to be enhanced. These same authore found that analysis of the cyclic voltammetry curves shows a $2 \mathrm{e}^{-}$reduction at $1 \mathrm{v} / \mathrm{s}$ but a $1 \mathrm{e}^{-}$process at $100 \mathrm{~V} / \mathrm{s}$. Thus, the fast scan potential is for the $\mathrm{TcO}_{4}^{-} / \mathrm{TcO}_{4}^{2-}$ redox couple. They

recomend a standard potential $\mathrm{E}^{0}=-0.61 \mathrm{~V}$ in $0.12 \mathrm{~mol} / 1 \mathrm{NaOH}$. Since their 1.0 mol/1 curve seems to give the same value, this was assumed equal to the I = 0 value.

This potential of $-0.61 \mathrm{~V}$ yields

$\Delta G_{\mathrm{rxn}}^{\circ}=58.9 \pm 1.7 \mathrm{~kJ} / \mathrm{mol}$ for the reaction

$$
\mathrm{T}^{2} \mathrm{O}_{4}^{-\infty}(\mathrm{aq})+\mathrm{e}^{-}(\mathrm{aq})=\mathrm{TcO}_{4}^{2-}(\mathrm{aq})
$$

However, this value is also equal to

$$
\Delta G_{\mathrm{rxn}}^{0}=\Delta G_{\mathrm{f}}^{0}\left[\mathrm{TcO}_{4}^{2-}(\mathrm{aq})\right]-\Delta G_{\mathrm{f}}^{0}\left[\mathrm{TcO}_{4}^{-}(\mathrm{aq})\right] .
$$

Therefore,

$$
\Delta G_{f}^{0}\left[\mathrm{TcO}_{4}^{2-}(\mathrm{aq})\right]=-562.2 \pm 10.0 \mathrm{~kJ} / \mathrm{mol}
$$

using our recommended value for $\mathrm{TcO}_{4}^{-}$, and assuming the redox potential was uncertain by $0.02 \mathrm{v}$.

Krychkov et al. ${ }^{185}$ studied the absorption spectra of $\mathrm{TcO}_{4}^{2-}$, produced by electron-beam pulsed radiolysis, at various $\mathrm{pH}$ values. Dissociation constants for $\mathrm{H}_{2} \mathrm{TcO}_{4}$ were obtained for these data. For aqueous

$$
\mathrm{HTcO}_{4}^{-}=\mathrm{TcO}_{4}^{2-}+\mathrm{H}^{+}
$$

they found $\mathrm{pK}_{2}=8.7 \pm 0.5$. Then, 
$\Delta G_{f}^{0}\left[\mathrm{HTcO}_{4}^{-}(\mathrm{aq})\right]=\Delta G_{f}^{0}\left[\mathrm{TcO}_{4}^{2-}(\mathrm{aq})\right]+\mathrm{RT} \operatorname{ln~K} \mathrm{K}_{2}=-611.9 \pm 10.5 \mathrm{KJ} / \mathrm{aol}$,

where $\Delta G_{f}^{0}\left[H^{+}(a q)\right]=0$ by convention.

A similar calculation can be done for the first acid dissociation of $\mathrm{H}_{2} \mathrm{TCO}_{4}$ :

$$
\mathrm{H}_{2} \mathrm{TcO}_{4}=\mathrm{H}^{+}+\mathrm{HTcO}_{4}^{-}
$$

for which they ${ }^{185}$ roughly estinated $\mathrm{pk}_{1}=0.3 \pm 0.8$. This gives

$\Delta G_{f}^{0}\left[\mathrm{H}_{2} \mathrm{TeO}_{4}(\mathrm{aq})\right]=\Delta \mathrm{G}_{\mathrm{f}}^{\mathrm{O}}\left[\mathrm{HTcO}_{4}^{-}(\mathrm{aq})\right]+\mathrm{RT} \operatorname{ln~K_{1}}=-613.6 \pm 12.1 \mathrm{~kJ} / \mathrm{mol}$,

which is well within the experimental uncertainty of $\Delta G_{f}^{0}\left[\mathrm{HTCO}_{4}^{-}(\mathrm{aq})\right]+\Delta \mathrm{G}_{\mathrm{f}}^{0}\left[\mathrm{H}^{+}(\mathrm{aq})\right]$. Thus, (as for $\mathrm{H}_{2} \mathrm{SO}_{4}$ ) the first acid dissociation can be treated as nearly complete.

Aqueous $\mathrm{TcO}_{4}^{3-}$ and Other Aqueous $\mathrm{Tc}(V)$ Species

It was noted in the section on solid Tc(v) oxyhalide salts that the $\mathrm{TcOCl}_{4}^{-}$ and $\mathrm{TcCCl}_{5}^{2-}$ anions can be isolated from the products of reduction of $\mathrm{TcO}_{4}^{-}$by concentrated HCl. This suggests that aqueous solutions of $\mathrm{Tc}(\mathrm{V})$ in noncomplexing media could contain $\mathrm{TcD}^{3+}$ and its various hydrolysis products: $\mathrm{TcO}(\mathrm{OH})^{2+}$, $\mathrm{TcO}(\mathrm{OH})_{2}^{+}$(or $\mathrm{TcO}_{2}^{+}$), $\mathrm{TcO}(\mathrm{OH})_{3}^{0}$ [or $\mathrm{TcO}_{2}(\mathrm{OH})^{\circ}$ ], and possibly dimeric or polymeric species. Several of these species were previously suggested by Bratu et al., ${ }^{183}$ but no thermodynamic data are available for any of them. "Strong hydrolysis" of $\mathrm{TcOCl}_{5}^{2-}$ was reported for $\mathrm{H}^{+}$concentrations below $3.15 \mathrm{~mol} / 1.193$

All of these $\mathrm{Tc}(V)$ cationic and neutral aqueous species seem to be unstable with regsrd to formation of $\mathrm{Tc}$ (VII) and $\mathrm{Tc}$ (IV). In the section on solid ternary oxides it was noted that while Tc(VII), Tc(VI), and Tc(IV) predominate, formation of $\mathrm{Tc}(V)$ double oxides can sometimes occur in the solid state. A number of ligand substituted oxytechnetium (V) complexes have been prepared which are possibly related to the hydrolyzed Tc $(V)$ species in aqueous solutions. 
Theae complexes contain cores of either $\mathrm{TcO}^{3+}$ (or its dimer $\mathrm{Tc}_{2} \mathrm{O}_{2}^{6+}$ ), trans- $\mathrm{TcO}_{2}^{+}$, or $\mathrm{Tc}_{2} \mathrm{O}_{3}^{4+} \cdot 160,194$

For electrolytic reduction of $\mathrm{TcO}_{4}^{-}$in acidic nedia, a $3 e^{-}$or $4 e^{-}$ reduction is usually observed wich produces a Tc(IV) or Tc(III) species. In neutral or basic solution, the reduction involves $2 e^{-}$or $3 e^{-}$dependirg on conditions. This case will concern us in this section since we are interested in Tc(v).

Miller et al. 195 obtained the sane value for the

$$
\operatorname{Tc}(\mathrm{VII})+2 \mathrm{e}^{-}=\mathrm{Tc}(\mathrm{V})
$$

reduction potential in $0.1 \mathrm{mol/1} \mathrm{NaOH}$, alkaline $\mathrm{KCl}$, and $\mathrm{NH}_{4} \mathrm{Cl}$. Sinilarly, Astheiver and Schwochau ${ }^{196}$ atudied this reduction potential in $0.1,0.5$, and $1.0 \mathrm{~mol} / 1 \mathrm{MaOH}$, and also LiCl solutions at these sase concentrations. While the reduction potentials depended on ionic strength, they were essentially equal in the MaH and LiCl solutions at the sawe ionic atrength. Likewise, Bratu et al. ${ }^{183}$ obtained identical reduction potentials for $0.1 \mathrm{nol} / \mathrm{l} \mathrm{KOH}$, $\mathrm{NaOH}$, or $\mathrm{KCl}$, and also for $1 \mathrm{~mol} / 1 \mathrm{NaClO}_{4^{-}}$. Russe11 and $\mathrm{Cash}^{177}$ likevise found that this reduction potential was $\mathrm{pH}$ independent. These studies indicate that no hydrogen ions participate in the $2 \mathrm{e}^{-}$reduction of $\mathrm{TCO}_{4}^{-}$in nonacidic solutions. Thus, the reaction is

$$
\mathrm{TcO}_{4}^{-}+2 \mathrm{e}^{-}=\mathrm{TcO}_{4}^{3-}
$$

Zhdanov et al. 191 studied the polarographic reduction of $\mathrm{TcO}_{4}^{-}$in acidic, neutral, and basic $\mathrm{Na}_{2} \mathrm{SO}_{4}$ solutions. The number of electrons involved in the reduction changed from three in neutral and acidic aolutions to two "one-electron" waves in alkaline solutions (they seen to have misidentified the first alkaline solution wave). They suggested that Te(iv) combines with fewer oxygen atom to produce this effect. However, for küH concentrations of $6 \times 10^{-3}=01 / 1$ and above, no shift in the reduction potential of the " ret wave occurred with increasing NaOH concentration (i.e. it is $\mathrm{pH}$ independent). This agrees with the 4 studies cited in the previous paragraph, and supporte $\mathrm{TcO}_{4}^{3-}$ as the $\mathrm{Tc}(\mathrm{V})$ epecies present. Solid $\mathrm{Li}_{3} \mathrm{TcO}_{3} 70$ has been prepered, but it is not known whether this $\mathrm{TcO}_{4}^{3-}$ has the sane structure as the aqueous species. 
$\mathrm{TcO}_{4}^{3-}$ in aqueous nonacidic solutions disproportionates by

$$
2 \mathrm{TcO}_{4}^{3-}=\mathrm{TcO}_{4}^{2-}+\mathrm{Tc}(\mathrm{IV})
$$

As noted earlier, $\mathrm{TcO}_{4}^{2-}$ is also unstable and disproportionate to form $\mathrm{TcO}_{4}^{3-}$ and $\mathrm{TcO}_{4}^{-}$. Thus, ultimately $\mathrm{TcO}_{4}^{3-}$ is converted to

$\mathrm{TcO}_{4}^{-}$and $\mathrm{Tc}$ (IV). Because of these complicaced reactions, the $\mathrm{TcO}_{4}^{-} / \mathrm{TcO}_{4}^{3-}$ redox couple is found to be irreveraible when investigated by atandard electrocheaical wethoda. The overal1 disproportionation reaction seema to be 183

$$
3 \mathrm{TcO}_{4}^{3-}=\mathrm{TcO}_{4}^{-}+2 \mathrm{Tc}(\mathrm{IV})
$$

The $1 e^{-}$reduction of $\mathrm{TcO}_{4}^{-}$to $\mathrm{TcO}_{4}^{2-}$ was also found to be irreversible by standard electrochemical methods, but it became reversible when fast-scan cyclic voltanetry was used. 186,187 The same procedure does not work for $\mathrm{TcO}_{4}^{-} / \mathrm{TcO}_{4}^{3-}$, since under fast-scan conditions the $2 \mathrm{e}^{-}$ irreversible reduction switches to a $1 e^{-}$reversible reduction. However, since the chenical nature of $\mathrm{TcO}_{4}^{3-}$ is very sivilar to $\mathrm{TcO}_{4}^{-}$, except for charge, the $2 \mathrm{e}^{-}$reduction potential may possibly give valid thermodynamic data.

There are numerous determinations of the $\mathrm{TcO}_{4}^{-} / \mathrm{TcO}_{4}^{3-}$ reduction potential, $21,53,95,177,182,183,186,195-198$ and they are sumarized in Table 4. All of these reduction potentials (except for Kuzina et al. 's 197 which is too high) were fitted to the least-squares equation $E(I)=E^{0}(I=0)+A V I$

Best values are $B(I=0)=-0.600 \mathrm{~V}, A=0.0639$, with a standard deviation of $0.026 \mathrm{~V}$. Magee et al. 199 obtained a sightly more negative reduction potential in $2 \mathrm{~mol} / 1 \mathrm{NaOH}$, but they thought it was for a $3 e^{-}$reduction. Salaria et a1.' $\mathrm{g}$ point ${ }^{200}$ of $-0.57 \mathrm{~V}$ at $\mathrm{pH}=13$ agrees with the results of Table 4 , but they likewise attributed it to a $3 \mathrm{e}^{-}$reduction. 
TABLE 4. Two electron reduction potentials of $\mathrm{TcO}_{4}^{-}$to $\mathrm{TcO}_{4}^{3-}$.

Potential, V vs NHE Ionic strength Media Reference

\begin{tabular}{|c|c|c|c|}
\hline-0.61 & 0.10 & KOH & Colton et al. 53 \\
\hline$\approx-0.56$ & 0.1 & $\begin{array}{l}\mathrm{NaOH}, \mathrm{NH}_{4} \mathrm{Cl} \text {, or } \\
\text { alkal ine } \mathrm{KCl}\end{array}$ & Hiller et al. 195 \\
\hline-0.55 & $?$ & $\begin{array}{l}\mathrm{pH}=10 \\
\text { borace buffer }\end{array}$ & Milier et al.195 \\
\hline-0.63 & 1.10 & $\mathrm{NaClO}_{4}+\mathrm{KOH}$ & Kusina et $a 1.197$ \\
\hline$-0.5 ? 1$ & 0.1 & $\mathrm{NaOH}$ & $\begin{array}{l}\text { As theimer and } \\
\text { Schwochau } 196\end{array}$ \\
\hline-0.534 & 0.5 & $\mathrm{NaOH}$ & $\begin{array}{l}\text { As theimer and } \\
\text { Schwochau } 196\end{array}$ \\
\hline-0.518 & 1.0 & $\mathrm{NaOH}$ & $\begin{array}{l}\text { As theimer and } \\
\text { Schwochau } 196\end{array}$ \\
\hline-0.575 & 0.1 & Licl & $\begin{array}{l}\text { As theimer and } \\
\text { Schwochau } 196\end{array}$ \\
\hline-0.541 & 0.5 & LiCl & $\begin{array}{l}\text { As theimer and } \\
\text { Schwochau } 196\end{array}$ \\
\hline-0.535 & 1.0 & LiC1 & $\begin{array}{l}\text { Astheimer and } \\
\text { Schwochau } 196\end{array}$ \\
\hline-0.568 & 0.6 & $\begin{array}{l}0.5 \mathrm{NaClO}_{4} \\
+0.1 \mathrm{NaOH}\end{array}$ & Minze 198 \\
\hline$\approx-0.55$ & 1.0 & $\mathrm{NaOH}$ & $\begin{array}{l}\text { Kisse1 and } \\
\text { Feldbezg } 182\end{array}$ \\
\hline-0.56 & 0.1 & $\frac{\mathrm{NaOH}, \mathrm{KO}}{\mathrm{KCI}, \text { or } \mathrm{LiC10}}$ & Bratu et a1. 183 \\
\hline-0.60 & 0.05 & $\left(\mathrm{C}_{2} \mathrm{H}_{5}\right)_{4} \mathrm{NC1O}_{4}$ & $\begin{array}{l}\text { Astheimer and } \\
\text { Schwochau } 95\end{array}$ \\
\hline-0.56 & $=0.1$ & $\mathrm{pH}=13 \mathrm{KOH}$ & $\begin{array}{l}\text { Russel1 and } \\
\text { Cash }^{177}\end{array}$ \\
\hline$=-0.58$ & 0.5 & $\mathrm{KC1}-\mathrm{NaOH}$ & Grassi et al. 21 \\
\hline$\simeq-0.56$ & 0.12 & $\mathbf{K O H}$ & Burst 186 \\
\hline
\end{tabular}


This least-squares potential at $I=0$ yields $\Delta G_{\text {rXn }}^{\circ}=1.15 .8 \pm 5.0 \mathrm{~kJ} / \mathrm{mol}$ for

$$
\mathrm{TcO}_{4}^{-}+2 \mathrm{e}^{-}=\mathrm{TcO}_{4}^{3-}
$$

and

$\Delta G_{f}^{0}\left[\operatorname{TcO}_{4}^{3-}(a q)\right]=\Delta G_{f}^{0}\left[\operatorname{TcO}_{4}^{-}(a q)\right]+\Delta G_{\mathrm{rX}:}^{0}=-505.3 \pm 11.2 \mathrm{~kJ} / \mathrm{mol}$.

$\mathrm{TcO}_{4}^{3-}$ is the fully dissociated form of the possibly hypothetical acid $\mathrm{H}_{3} \mathrm{TcO}_{4}$, but no dissociation constant data are available for it.

In the diacussion of $\mathrm{TcO}_{4}^{2-}$, it was noted that the disproportionation reaction

$$
2 \mathrm{TcO}_{4}^{2-}=\mathrm{TcO}_{4}^{-}+\mathrm{TcO}_{4}^{3-}
$$

appears to occur rapidly and extensively. For this reaction,

$$
\begin{gathered}
\Delta G_{\mathrm{rXn}}^{0}=\Delta G_{\mathrm{f}}^{0}\left[\mathrm{TcO}_{4}^{-}(\mathrm{aq})\right]+\Delta G_{\mathrm{f}}^{0}\left[\mathrm{TcO}_{4}^{3-}(\mathrm{aq})\right]-2 \Delta G_{\mathrm{f}}^{0}\left[\mathrm{TcO}_{4}^{2-}(\mathrm{aq})\right] \\
=-2.0 \pm 12 \mathrm{~kJ} / \mathrm{mol}
\end{gathered}
$$

and

$\mathrm{K}=\frac{\left[\mathrm{TcO}_{4}^{-}\right]\left[\mathrm{TcO}_{4}^{3-}\right]}{\left[\mathrm{TcO}_{4}^{2-}\right]^{2}}=2.2$

This $\mathrm{K}$ value is uncertain by about 2 orders of magnitude. Since $\mathrm{TcO}_{4}^{3-}$ also decomposes, this value nay be reasonable.

It has been suggested that in acidic solutions, $\mathrm{TcO}_{4}^{3-}$ decomposes by the reaction 198

$$
\mathrm{TcO}_{4}^{3-}+2 \mathrm{H}^{+}=\mathrm{TcO}_{3}^{-}+\mathrm{H}_{2} \mathrm{O}
$$

No thermodynamic data are available for $\operatorname{TcO}_{3}^{-}$to check this assumption. The emf data for reduction of $\mathrm{TcO}_{4}^{-}$in alkaline media indicate the $1 \mathrm{e}^{-}$and $2 \mathrm{e}^{-}$processes have nearly identical redox potentials. That the $2 e^{-}$process is usually observed owes more to kinetics than thermodynamics. 
In addition, a catalytic $\mathrm{H}_{2} \mathrm{O}_{2}$ polarographic wave can occur in the same 201 potential region.

Polarography, Coulometry, and the Identification of Tc Aqueous Species

Polarography and controlled-potential coulometry provide methods for determining the number of electrons involved in an electrolytic reduction or oxidation. Together with the observed dependence (or lack of a dependence) of this process on $\mathrm{pH}$, the chemistry of the apecies involved can be deduced. For example, a pH independent $2 \mathrm{e}^{-}$reduction of $\mathrm{TCO}_{4}^{-}$in aqueous alkaline media clearly would correapond to the formation $\mathrm{TcO}_{4}^{3-}$. Unfortunately, unambigious results are rarely available for aqueous Tc species.

Some of the difficulties have already been described. For examples, virtually all of the aqueous redox processes involving Tc are irreversible, product disproportionation or reaction with water frequently occurs, catalytic discharge of $\mathrm{H}_{2}$ sometimes occurs close to $\mathrm{Tc}$ reduction waves, and conflicting claims are sometimes made about the number of electrons involved in a particular redox process. Attempts to determine the number of electrons involved in a reduction process by polarography and controlled potential reduction sometimes give different values at the same reduction potential.

Differences between the two methods have been attributed either to absorption phenomena ${ }^{21}$ on the electrode surface, or to polarography and coulometry sometimes seeing different reactions due to different time scales. 202,203 For example, aqueous $\mathrm{TcO}_{4}^{-}$can be reduced by $2 e^{-}$to form $\mathrm{TcO}_{4}^{3-}$ in basic solutions as indicated by polarography. In contrast, if controlled potential coulometry is used, then a $3 \mathrm{e}^{-}$reduction is observed at the same potential. However, $\mathrm{TcO}_{4}^{3-}$ is unatable with regard to diaproportionation to $\mathrm{TcO}_{4}^{-}$and $\mathrm{Tc}$ (IV) as noted earlier. Under controlled potential conditions this "new" $\mathrm{TcO}_{4}^{-}$would then be reduced to $\mathrm{TcO}_{4}^{3-}$, etc., with all of the $\mathrm{TcO}_{4}^{-}$eventually ending up as $\mathrm{Tc}$ (IV). Thus, the different methods have different time scales and so observe different reactions.

These differences agree with Crouthamel's potentiometric reduction of $\mathrm{TCO}_{4}^{-}$in 12 mol/1 $\mathrm{H}_{2} \mathrm{SO}_{4}$ with $\mathrm{Ti}$ (III). ${ }^{189}$ Rapid titration gave potential breaks corresponding to formation of both $\mathrm{Tc}(\mathrm{V})$ and $\mathrm{Tc}(\mathrm{IV})$. However, if the titration was interrupted before the second end point, the 
potential would then increase for about one hour. By doing this at several points during the titration process (equivalent to a very slow titration), a titration curve was obtained with a single break at Tc(IV). These are clearly the potentiometric titration equivalents of polarography and controlled potential coulometry.

Controlled potential coulometry indicates a $4 \mathrm{e}^{-}$reduction of $\mathrm{TcO}_{4}^{-}$ in neutral and acidic solution. In basic solutions $3 \mathrm{e}^{-}$or $4 \mathrm{e}^{-}$can occur, with $3 e^{-}$usually obtiined for potentials of -0.5 to $-0.6 \mathrm{~V}$, and $4 \mathrm{e}^{-}$for more negative potentials. These coulometric data have been tabulated by Russel1 and Cash. 177 They also tabulate conflicting polarographic results as to whether the reduction in base at $-0.6 \mathrm{v}$ involves $2 \mathrm{e}^{-}$or $3 \mathrm{e}^{-}$, and whether the -0.8 to $-0.9 \mathrm{~V}$ peak involves $3 \mathrm{e}^{-}$or $4 \mathrm{e}^{-}$.

It is well known that in acid solution $\mathrm{TcO}_{4}^{-}$can be reduced by metallic $\mathrm{Hg}$ to form lower valence Tc species, with the reduction ultimately proceeding to Tc metal at longer contact times. $11,191,197,203,204$ similar results have been reported in $\mathrm{HCl}, \mathrm{HClO}_{4}$, and $\mathrm{H}_{2} \mathrm{SO}_{4}$ solutions, and the reaction rate seems to increase with increased acidity. Prolonged contact with $\mathrm{Hg}(1)$ can yield solutions that show only $\mathrm{Hg}^{2+}$ polarographic waves. Polarographic waves are usually measured with dropping mercury electrodes. Thus, in acidic solutions, some prereduction of Tc by $\mathrm{Hg}$ can occur, which further complicates the interpretation of results.

${\underline{\text { Aqueous }} \mathrm{TcO}^{2+}, \mathrm{TcO}(\mathrm{OH})^{+}}^{+}, \mathrm{TcO}(\mathrm{OH})_{2}^{0},\left[\mathrm{TcO}(\mathrm{OH})_{2}^{\circ}\right]_{2}$, Colloidal $\mathrm{TcO}_{2}$, and other Tc(iv) Species

Important information about the valence of Tc in aqueous solutions can sometimes be obtained by examining compounds that precipitate when their solubility limits have been exceeded. Salaria et a1. 200,203 found that a $3 e^{-}$reduction of $\mathrm{TcO}_{4}^{-}$in acidic solution produced " $\mathrm{TcO}_{2}$ " for initial $\mathrm{pH}$ values of -0.3 to 2.0. Mazzocchin et al. ${ }^{205}$ produced $\mathrm{TcO}_{2} \cdot 2 \mathrm{H}_{2} \mathrm{O}$ by coulometric reduction of $\mathrm{TcO}_{4}^{-}$above $\mathrm{pH}=3$. These compounds are probably identical and equivalent to Carteledge's ${ }^{78} \mathrm{Tc}(\mathrm{OH})_{4}$ (diffraction data cannot tell any difference since they are amorphous). This same substance was also obtained by adding base to electrolytically reduced $\mathrm{TcO}_{4}^{-} 147$

$\mathrm{TcO}_{2} \cdot 2 \mathrm{H}_{2} \mathrm{O}$ can also be produced by raising the $\mathrm{pH}$ of very acidic solutions of $\mathrm{Tc}$ (IV). Spitsyn et $\mathbf{a l} .{ }^{45}$ found that the Tc(IV) spectra changed above $\mathrm{pH}=4$ and $\mathrm{TcO}_{2} \cdot 2 \mathrm{H}_{2} \mathrm{O}$ precipitated. Likewise, Paquette et al. 206 
reported that reduction of $\mathrm{TcO}_{4}^{-}$above $\mathrm{pH}=4$ also produced $\mathrm{TcO}_{2} \cdot 2 \mathrm{H}_{2} \mathrm{O}$, as did Owunwanne et al. ${ }^{74}$ by hydrolysis of Tc(IV). There is little doubt that $\mathrm{Tc}$ (IV) is produced by reduction of $\mathrm{TcO}_{4}^{-}$in acidic solution, and that $\mathrm{TcO}_{2} \cdot 2 \mathrm{H}_{2} \mathrm{O}$ precipitates above $\mathrm{pH}=3$ or 4 .

As discussed earliex, salts of the type $\operatorname{Tcx}_{6}^{2-}\left(X=\mathrm{Cl}^{-}, \mathrm{Br}^{-}\right.$,

$I^{-}$, or $F^{-}$) are well known in the solid atate and in aqueous solution. Koyama et al. 207 and Kanchiku ${ }^{208}$ have studied the aquation (replacement of $\mathrm{Cl}^{-}$by $\mathrm{H}_{2} \mathrm{O}$ ) of $\mathrm{TcCl}_{6}^{2-}$ alts in aqueous $\mathrm{HCl}$ solutions. $\mathrm{TcCl}_{6}^{2-}$

salts are kinetically inert in the dark but undergo aquation when exposed to visible or UV light. The extent of aquation depend on HCl concentration. Species separated by ion-exchange are $\operatorname{TcCl}_{6}^{2-}, \operatorname{Tc}_{2}\left(\mathrm{H}_{2} \mathrm{O}\right) \mathrm{Cl}_{5}^{-}$, $\mathrm{Tc}\left(\mathrm{H}_{2} \mathrm{O}\right)_{2} \mathrm{Cl}_{4}^{\circ}$, and $\mathrm{Tc}\left(\mathrm{H}_{2} \mathrm{O}_{3} \mathrm{Cl}_{3}^{+}\right.$. The first two ions were characterized both in terma of charge and $\mathrm{TC} / \mathrm{Cl}$ ratio. The neutril species and the cation were characterized in term of charge, but they could not be removed from the ion-exchange resin without decomposition. That is, the experiments could not tell $\mathrm{Tc}\left(\mathrm{H}_{2} \mathrm{O}\right)_{2} \mathrm{Cl}_{4}^{\circ}$ from $\mathrm{Tc}_{2}\left(\mathrm{H}_{2} \mathrm{O}\right)_{2}(\mathrm{OH}) \mathrm{Cl}_{3}^{\circ}$,

etc. These aquo-type complexes seem to exist only in complexing media. In weakly complexing or noncomplexing media, hydrolysis is quite extensive. In fact, Koyama et al. 207 suggested that

$$
\mathrm{Tc}\left(\mathrm{H}_{2} \mathrm{O}\right) \mathrm{Cl}_{5}^{-}=\mathrm{Tc}(\mathrm{OH}) \mathrm{Cl}_{5}^{2-}+\mathrm{H}^{+}
$$

could occur subsequent to the aquation of $\operatorname{TcCl}_{6}^{2-}$.

At $\mathrm{pH}$ values of about 1 to 3 , there is strong evidence for the nature of hydrolyzed Tc(IV) in aqueous solution. Gorski and Koch ${ }^{75}$ studied the electrophoretic mobility of $\mathrm{Tc}$ (IV) in $\mathrm{KNO}_{3}$ solutions and found sharp decreases around $\mathrm{pH}=1.3$ and 2.15. The mobility decreased to zero about $\mathrm{pH}=2.2$. This decrease to zero probably corresponds to formetion of a neutral species, and the two previous breaks to stepwise hydrolysis. That is,

$$
\mathrm{TcO}^{2+}+\mathrm{H}_{2} \mathrm{O}=\mathrm{TcO}(\mathrm{OH})^{+}+\mathrm{H}^{+}
$$

and

$$
\mathrm{TCO}(\mathrm{OH})^{+}+\mathrm{H}_{2} \mathrm{O}=\mathrm{TcO}(\mathrm{OH})_{2}^{\mathrm{O}}+\mathrm{H}^{+}
$$

are the probable reactions. As noted above, $\mathrm{TcO}^{2+}$ and $\mathrm{Tc}(\mathrm{OH})_{2}^{2+} \operatorname{cannot}$ be distinguished by these methods. 
Orrunwanne et a1. 74 studied the charge on Tc(IV) prepared by $\mathrm{Sn}^{2+}$ reduction of $\mathrm{TCO}_{4}^{-}$in perchlorate solutions using ion-exchange techniques. For $2.0>\mathrm{pH}>1.1$ they verified that the overnll charge on Tc(IV) was 2+. By $\mathrm{pH}=2.2$, however, the slope of the distribution curve changed owing to further hydrolysis. Spitayn et 21.45 studied the brown solution formed from the dissolution of $\mathrm{TcO}_{2} \cdot 2 \mathrm{H}_{2} \mathrm{O}$ in $\mathrm{H}_{2} \mathrm{SO}_{4}$ solutions. The solution species was not solloidal and had a charge of 2-. Ite probable formula was $\mathrm{Tc}(\mathrm{OH})_{2}\left(\mathrm{SO}_{4}\right)_{2}^{2-}$. The ionized form of this would contain the $\mathrm{Tc}(\mathrm{OH})_{2}^{2+}$ or $\mathrm{TcO}^{2+}$ ion. Sundrehagen ${ }^{76}$ aw no evidence for $\mathrm{TcO}^{2+}$ in his optical density study of $\mathrm{Tc}$ (IV) for $\mathrm{pH} \geq 1.3$, but this is the region where further hydrolyais of $\mathrm{TcO}^{2+}$ is atarting to occur.

Three studies provide both qualitative and quantitative information about the additional hydrolysis of $\mathrm{TcO}^{2+}$. These are the electrophoresis study of Gorski and Roch, 75 the solvent extraction study of Guénnec and Guillaumont, ${ }^{209}$ and Sundrehagen's ${ }^{76}$ absorption spectra study. They lead to the stepwise hydrolysis mechanism

$$
\begin{aligned}
& \mathrm{TcO}^{2+}+\mathrm{H}_{2} \mathrm{O}=\mathrm{TcO}(\mathrm{OH})^{+}+\mathrm{H}^{+} \\
& \mathrm{TcO}(\mathrm{OH})^{+}+\mathrm{H}_{2} \mathrm{O}=\mathrm{TcO}(\mathrm{OH})_{2}^{\circ}+\mathrm{H}^{+} \\
& 2 \mathrm{TcO}(\mathrm{OH})_{2}^{\mathrm{O}}=\left[\mathrm{TcO}(\mathrm{OH})_{2}^{\circ}\right]_{2} .
\end{aligned}
$$

Sundrehagen ${ }^{76}$ found no evidence for trimer formation.

Lefort ${ }^{73}$ reported that the solubility of $\mathrm{TcO}_{2} \cdot 2 \mathrm{H}_{2} \mathrm{O}$ was approximately $5 \times 10^{-4} \mathrm{~mol} / 1$ in 0.05 and $0.5 \mathrm{~mol} / 2 \mathrm{H}_{2} \mathrm{SO}_{4}$. We earlier concluded that $\mathrm{TcO}_{2} \cdot 2 \mathrm{H}_{2} \mathrm{O}$ precipitates by $\mathrm{pH}=3$ or 4 . Below $\mathrm{pH}=3$ or 4, concentrations exceeding the solubility can exist as colloidal naterial. No11 et a1. 210 found that $10^{-2}$ mol/1 $\mathrm{Tc}$ (IV) exists predominately as a colloid above $\mathrm{pH}=0.5$ (this is much above Lefort's ${ }^{73}$ solubility).

Thus the following picture has emerged for the hydrolysis of Tc(IV). For $\mathrm{pH}$ about 1.5 and $1 \mathrm{es}, \mathrm{Tc}(\mathrm{IV})$ exists predoainately as $\mathrm{TcO}^{2+}$. Between $\mathrm{pH}=$ 1.5 and $2.2, \mathrm{TcO}^{2+}$ hydrolyzea further to form $\mathrm{TcO}(\mathrm{OH})^{+}$and $\mathrm{TcO}(\mathrm{OH})_{2}^{0}$. By $\mathrm{pH}=2.7$ most of the $\mathrm{Tc}(\mathrm{IV})$ exists as $\mathrm{TrO}(\mathrm{OH})_{2}^{\circ}$ or $\left[\mathrm{TcO}(\mathrm{OH})_{2}^{\circ}\right]_{2}$, 
and above $\mathrm{pH}=3$ or $4 \mathrm{TcO}_{2} \cdot 2 \mathrm{H}_{2} \mathrm{O}$ pracipitates. Below $\mathrm{pH}=3$ to $4, \mathrm{Tc}$ (IV) exists as a colloid if the solubility limit is exceeded. It is possible (but not established) that a $\mathrm{Tc}^{4+}$ aquo ion could exiat if $\left[\mathrm{H}^{+}\right]$is several mol/1. It was previously noted that a $2 \mathrm{e}^{-}$reduction of $\mathrm{TcO}_{4}^{-}$to $\mathrm{TcO}_{4}^{3-}$ occurs in aqueous alkaline solution at about $-0.6 \mathrm{~V}$. There are a few claims that a $3 \mathrm{e}^{-}$polarographic reduction can also occur in neutral and alkaline media at nearly this same potential. $20,174,177$ Some of these same authors also observed the $2 \mathrm{e}^{-\infty}$ reduction at this potential under very similar conditions. However, in alkaline solutions controlled potential coulometry gives $3 \mathrm{e}^{-}$, whereas it gives $4 \mathrm{e}^{-}$for neutral and acidic solutions. At this potential 177 our analysis of polarographic data indicates a $2 a^{-}$reduction of $\mathrm{TcO}_{4}^{-}$to $\mathrm{TcO}_{4}^{3-}$, with the $3 \mathrm{e}^{-}$reduction being rendered unlikely under these conditions on kinetic grounds (although it can occur in coulometry).

In neutral and basic solutions (and occasionally even in acidic solutions) a second polarographic reduction wave is usua11y observed between -0.7 and $-0.9 \mathrm{~V}$, with the potential depending more on ionic strength than pH. Unfortunately, this wave is very il1-defined compared to most polarographic waves and consequently harder to characterize. Its potential can rarely be estimated to better than $0.1 \mathrm{~V}$. The first reduction wave of $\mathrm{TcO}_{4}^{-}$will be discussed later.

There is some controversy as to the polarographic reduction processes involved with the -0.7 to $-0.9 \mathrm{~V} \mathrm{TcO}_{4}^{-}$reduction wave in alkaline media. Some workers clain that a $3 e^{-}$reduction occurs to form Tc(IV). 21,176,196,202 In contrast, other workers claim this reduction involves $4 \mathrm{e}^{-}$to form $\mathrm{Tc}$ (III). 200,203 However, the workers who thought that the reduction was to Tc(III) also claimed the first reduction wave at $\simeq-0.6 \mathrm{~V}$ was to $\mathrm{Tc}(\mathrm{IV})$, and not to $\mathrm{Tc}(\mathrm{V})$ as concluded here. Magee et al. 199 also thought the first wave was a $3 \mathrm{e}^{-}$reduction, but could nut identify the second wave. Controlled potential coulometry indicates a $4 \mathrm{e}^{-}$ reduction at -0.7 to $-0.9 \mathrm{~V}$ in alkaline media, but the time scale is much longer than for polarography. We tentatively conclude that the -0.7 to $-0.9 \mathrm{~V}$ polarographic wave involves reduction of $\mathrm{TcO}_{4}^{-}$to $\mathrm{Tc}$ (IV) aqueous species. For acidic media, there are also claims of a $7 e^{-}$reduction of $\mathrm{TcO}_{4}^{-}$ directly to the metal at $\approx-0.7 \mathrm{v} .^{177}$

There are other conflicting claims that this polarographic alkaline 
solution wave actually corresponds to a $1 \mathrm{e}^{-}$reduction of $\mathrm{Tc}(\mathrm{V})$, which had formed by the $2 e^{-}$reduction of $\mathrm{TCO}_{4}^{-}$at $\simeq-0.6 \mathrm{v}^{53}$ Alternately, Russell and Cash ${ }^{177}$ found the second wave could correspond to 3 to $5 e^{-}$ reductions of $\mathrm{TCO}_{4}^{-}$depending on system characteristics.

We have noted that for a pH of 3 or 4 and above, $\mathrm{TcO}_{2} \cdot 2 \mathrm{H}_{2} \mathrm{O}$ precipitates from solutions of $\mathrm{Tc}$ (IV). For the polarographic wave at -0.7 to $-0.9 \mathrm{v}_{\varepsilon}$ a $3 \mathrm{e}^{-}$reduction of $\mathrm{TcO}_{4}^{-}$in alakline solution would give $\mathrm{TeO}_{2} \cdot 2 \mathrm{H}_{2} \mathrm{O}$ direciiy as the thermodynamically atable product. However, Cartledge and Smith ${ }^{77}$ found the $\mathrm{TCO}_{4}^{-} / \mathrm{TCO}_{2}-2 \mathrm{H}_{2} \mathrm{O}$ cell to be very low to reach equilibrium in acidic solution, and a similar vituation might be true in basic solution. That is, because of elow kinetics it is not clear what form of $\mathrm{Tc}$ (IV) this $3 \mathrm{e}^{-}$reduction corresponds to.

Several obviows possible reduction schemes for the second wave include direct reduction 21,191

$$
\mathrm{TcO}_{4}^{-}+3 \mathrm{e}^{-}+2 \mathrm{H}_{2} \mathrm{O}=\mathrm{TcO}_{2}++4 \mathrm{OH}^{-}
$$

Alternately, reduction could occur by

$$
\mathrm{TcO}_{4}^{-}+3 e^{-}=\mathrm{TcO}_{4}^{4-}
$$

to be followed later by

$$
\mathrm{TcO}_{4}^{4-}+\mathrm{H}_{2} \mathrm{O}=\mathrm{TcO}_{3}^{2-}+2 \mathrm{OH}^{-}
$$

and then

$$
\mathrm{TcO}_{3}^{2-}+\mathrm{H}_{2} \mathrm{O}=\mathrm{TcO}_{2}++2 \mathrm{OH}^{-}
$$

Another possibility is that this second wave represents 198

$$
\mathrm{TCO}_{4}^{3-}+\mathrm{e}^{-}+\mathrm{H}_{2} \mathrm{O}=\mathrm{TCO}_{3}^{2-}+2 \mathrm{OH}^{-} \text {. }
$$

where the $\mathrm{TcO}_{4}^{3-}$ would be forned during the first reduction wave. Since the reduction mechanism is uncertain, and the second reduction wave poorly defined, no attempt will be made to extract thernodynamic data from it. 
For want of better data, Lefort's approximate solubilities ${ }^{73}$ of $\mathrm{TcO}_{2} \cdot 2 \mathrm{H}_{2} \mathrm{O}$ will be analyzed to yield the solubility product. Since the least hydrolyzed form of $\mathrm{Tc}$ (IV) was found to be $\mathrm{TcO}^{2+}$, we will express the solubility of $\mathrm{TcO}_{2} \cdot 2 \mathrm{H}_{2} \mathrm{O}$ in terms of it by the equation

$$
\mathrm{TcO}_{2} \cdot 2 \mathrm{H}_{2} \mathrm{O}(\mathrm{am})=\mathrm{TcO}^{2+}+2 \mathrm{OH}^{-}+\mathrm{H}_{2} \mathrm{O}(1) .
$$

The solubility product is then given by

$$
K_{g}=\frac{\left[\mathrm{TcO}^{2+}\right]\left[\mathrm{H}_{2} \mathrm{O}\right]\left[\mathrm{OH}^{-}\right]^{2}}{\left[\mathrm{TcO}_{2} \cdot 2 \mathrm{H}_{2} \mathrm{O}\right]}-\left[\mathrm{TcO}^{2+}\right]\left[\mathrm{H}_{2} \mathrm{O}\right]\left[\mathrm{OH}^{-}\right]^{2}
$$

Lefort measured the total solubility of $\mathrm{Tc}$ (IV) in 0.05 and $0.5 \mathrm{~mol} / 1 \mathrm{H}_{2} \mathrm{SO}_{4}$ solutions to be approximately $5 \times 10^{-4} \mathrm{~mol} / 1^{73}$ This is a total solubility, $S$, and is due to a number of species present:

$\left.\mathrm{S}=\left[\mathrm{TcO}^{2+}\right]+\left[\mathrm{TcO}(\mathrm{OH})^{+}\right]+\left[\mathrm{TcO}(\mathrm{OH})_{2}^{0}\right]+\left[\left(\mathrm{TcO}^{\circ} \mathrm{OH}\right)_{2}\right)_{2}^{0}\right]$

+ [colloidal material] + [sulfate complexes] -

Colloidal material is known to be present in acidic solutions of Tc(IV) above its solubility limit, but is it not known whether any was present in Lefort's solutions. Its presence must be neglected for want of better information.

Gorski and $\mathrm{Koch}^{75}$ studied the hydrolysis of $\mathrm{TcO}^{+2}$ at an ionic strength of $0.1 \mathrm{~mol} / 1$ using electrophoresis. The first hydrolysis step

$$
\mathrm{TcO}^{2+}+\mathrm{H}_{2} \mathrm{O}=\mathrm{TcO}(\mathrm{OH})^{+}+\mathrm{H}^{+}
$$

had a hydrolysis constant of 
$\mathrm{K}_{\mathrm{h} 1}=\frac{\left[\mathrm{TcO}(\mathrm{OH})^{+}\right]\left[\mathrm{H}^{+}\right]}{\left[\mathrm{TcO}^{2+}\right]\left[\mathrm{H}_{2} \mathrm{O}\right]}=(4.3 \pm 0.4) \times 10^{-2}$

For the second hydrolysis step,

$$
\mathrm{TcO}(\mathrm{OH})^{+}+\mathrm{H}_{2} \mathrm{O}=\mathrm{TcO}(\mathrm{OH})_{2}^{\circ}+\mathrm{H}^{+}
$$

and the hydrolysis constant is given by

$$
K_{h 2}=\frac{\left[\operatorname{TcO}(\mathrm{OH})_{2}^{0}\right]\left[\mathrm{H}^{+}\right]}{\left[\mathrm{TcO}(\mathrm{OH})^{+}\right]\left[\mathrm{H}_{2} \mathrm{O}\right]}
$$

Three determinations of $\mathrm{k}_{\mathrm{h} 2}$ have been made, Guénnec and Guillaumont ${ }^{209}$ obtained $=0.1$ by liquid extraction. Gorski and Koch $^{75}$ obtained $\mathrm{K}_{\mathrm{h} 2}=(3.7 \pm 0.4) \times 10^{-3}$ in $0.1 \mathrm{KNO}_{3}$ mol/1 solution. A similar value of $k_{h 2}=(9.3 \pm 2.0) \times 10^{-3}$ in $0.2 \mathrm{~mol} / 1 \mathrm{HClO}_{4}+\mathrm{NaClO}_{4}$ was reported by Sundrehagen. ${ }^{76}$ These latter two values ${ }^{75,76}$ appear to be the more reliable and were accepted for subsequent calculations. Extrapolations to infinite dilution, or to any other ionic strength, were made with Helgeson's B-dot approach, ${ }^{211}$ which is a modification of the Akerlöf-Thomas rule. ${ }^{212}$ A constant ion-size of $3.65 \mathrm{~A}$ was assumed for all Tc ions since no experimental values are available.

The dimerization reaction

$$
2 \mathrm{TcO}(\mathrm{OH})_{2}^{\mathrm{o}}=\left[\mathrm{TcO}(\mathrm{OH})_{2}^{\mathrm{o}}\right]_{2}
$$

was also studied by Sundrehagen ${ }^{76}$ who obtained

$$
\mathrm{K}_{\mathrm{d}}=\frac{\left[\left(\mathrm{TcO}(\mathrm{OH})_{2}\right)_{2}^{\circ}\right]}{\left[\mathrm{TcO}(\mathrm{OH})_{2}^{\circ}\right]^{2}}=(3.14 \pm 0.28) \times 10^{6} .
$$


This value will be assumed to be independent of ionic strength since both species involved are neutral.

Sulfate complexes are known to form for $\mathrm{TcO}^{2+}, 45$ but unfortunately no quantitative data are available. The stability constants of simple divalent metal sulfates $\mathrm{MSO}_{4}$ have very sinilar values. A similar situation may occur for $\mathrm{MOSO}_{4}$ salts also. Consequently, data for $\mathrm{RuOSO}_{4}$ were used to estimate the stability constant $\mathrm{K}_{\text {ip }}$ for $\mathrm{TcOSO}_{4}$ in $\mathrm{H}_{2} \mathrm{SO}_{4}$ solutions. 213

The solubility calculation requires values of $\left[\mathrm{OH}^{-}\right]$and $\left[\mathrm{SO}_{4}^{2-}\right]$ for the two $\mathrm{H}_{2} \mathrm{SO}_{4}$ solutions. They were taken from Wirth ${ }^{214}$ who reported free sulfate concentration in $\mathrm{H}_{2} \mathrm{SO}_{4}$ solutions (graphically), and also free $\mathrm{H}^{+}$concentrations.

The total slubility in these $\mathrm{H}_{2} \mathrm{SO}_{4}$ solutions is then given by the complicated expression

$$
\begin{aligned}
& S=\frac{\mathrm{K}_{s}}{\left[\mathrm{H}_{2} \mathrm{O}\right]\left[\mathrm{OH}^{-}\right]^{2}}+\frac{\left[\mathrm{SO}_{4}^{2-}\right]}{\left[\mathrm{H}_{2} \mathrm{O}\right]\left[\mathrm{OH}^{-}\right]^{2}} \mathrm{~K}_{\mathrm{ip}_{\mathrm{s}} \mathrm{K}_{s}}+\frac{\mathrm{K}_{\mathrm{s}} \mathrm{K}_{\mathrm{h} 1}}{\mathrm{~K}_{\mathrm{w}}\left[\mathrm{H}_{2} \mathrm{O}\right]\left[\mathrm{OH}^{-}\right]} \\
& +\frac{K_{s} K_{h 1} K_{h 2}}{K_{w}^{2}\left[H_{2} O\right]}+\frac{K_{s}^{2} K_{h 1}^{2} K_{h 2}^{2} K_{d}}{K_{w}^{4}\left[H_{2} O\right]^{4}},
\end{aligned}
$$

where $\mathrm{K}_{\mathrm{w}}=10^{-14}$ is the ionization constant for $\mathrm{H}_{2} \mathrm{O}$. Lefort's $\operatorname{data}^{73}$ then yield $\mathrm{K}_{8}=2.6 \times 10^{-31}\left(3.2 \times 10^{-30}\right.$ if sulfate complexes are neglected) for $0.05 \mathrm{~mol} / 1 \mathrm{H}_{2} \mathrm{SO}_{4}$. In $0.5 \mathrm{~mol} / 1 \mathrm{H}_{2} \mathrm{SO}_{4}, \mathrm{~K}_{\mathrm{s}}=7.5 \mathrm{x}$ $10^{-33}\left(1.3 \times 10^{-31}\right.$ neglecting sulfate complexes). Extrapolation to infinite dilution and averaging gives

$$
\log _{10} K_{8}^{0}=-33.45 \pm 1.0
$$

Allard et al. 15 used Pourbaix's correlation of solubilities with hydrolysis constants to estimate

$$
\log _{10} k_{8}^{0}=-31
$$

The agreement of experimental and estimated values is fairly reasonsble, so their average of $-32.2 \pm 1.3$ will be accepted as the best current estimate. 
For the solution reaction,

$$
\mathrm{TcO}_{2} \cdot 2 \mathrm{H}_{2} \mathrm{O}=\mathrm{TcO}^{2+}+\mathrm{H}_{2} \mathrm{O}+2 \mathrm{OH}^{-}
$$

the free energy change is given by

$$
\begin{aligned}
& \Delta G_{s o 1}^{\circ}=\Delta G_{f}^{\circ}\left[\mathrm{TcO}^{2+}(\mathrm{aq})\right]+\Delta G_{f}^{O}\left[\mathrm{H}_{2} \mathrm{O}(1)\right]+2 \Delta G_{f}^{O}[\mathrm{OH}(\mathrm{aq})] \\
& -\Delta G_{f}^{0}\left[\mathrm{TcO}_{2} \cdot 2 \mathrm{H}_{2} \mathrm{O}(\mathrm{am})\right]=\Delta G_{f}^{0}\left[\mathrm{TcO}^{2+}(\mathrm{aq})\right]+284.4
\end{aligned}
$$

where CODATA values were used for $\mathrm{H}_{2} \mathrm{O}$ and $\mathrm{OH}^{-}$, and $\mathrm{TcO}_{2} \cdot 2 \mathrm{H}_{2} \mathrm{O}(\mathrm{am})$ was obtained earlier. However, we also know

$$
\begin{aligned}
\Delta G_{s 01}^{\circ} & =-R T \ln K_{s} \\
& =183.8 \pm 7.4 \mathrm{KJ} / \mathrm{mol}
\end{aligned}
$$

from the above solubility data. Thus,

$$
\Delta G_{f}^{0}\left[\mathrm{TcO}^{2+}(\mathrm{aq})\right]=-100.6 \pm 10.5 \mathrm{KJ} / \mathrm{mol}
$$

Using hydrolysis constant data extrapolated to infinite dilution and dimerization constant data allows free energies of formation to be calculated for other Tc(IV) species. Results are $\Delta G_{f}^{0}\left[\mathrm{TcO}(\mathrm{OH})^{\dagger}(\mathrm{aq})\right]=-331.3 \pm 10.5 \mathrm{KJ} / \mathrm{mol}$, $\Delta G_{\mathrm{f}}^{0}\left[\mathrm{TcO}(\mathrm{OH})_{2}^{\circ}(\mathrm{aq})\right]=-556.0 \pm 10.5 \mathrm{~kJ} / \mathrm{mol}$, and $\Delta G_{\mathrm{f}}^{\circ}\left[\left(\mathrm{TcO}(\mathrm{OH})_{2}^{\circ}\right)_{2}(\mathrm{aq})\right]=-1149.2$ $\pm 21.3 \mathrm{KJ} / \mathrm{mol}$.

A more detailed study of the solubility of $\mathrm{TcO}_{2} \cdot 2 \mathrm{H}_{2} \mathrm{O}$ would be very desirable since it would provide more accurate data for all of the Tc (IV) aqueous species. This study should be made in noncomplexing media to avoid corrections for sulfate complexes.

Aqueous $\mathrm{Tc}^{3+}, \mathrm{TcO}^{+}, \mathrm{Tc}^{2+}$, and other Lower Valence Tc Species

As noted above, polarographic reduction of $\mathrm{TcO}_{4}^{-}$in aqueous acidic solutions is generally reported to involve an initial $3 \mathrm{e}^{-1}$ or $4 \mathrm{e}^{-}$ reduction. This polarographic reduction wave is $\mathrm{pH}$-dependent and irreversible. A second irreversible reduction is usually observed that io pH-independent, and it is generally considered to correspond to formation of metallic Tc. A very large catalytic wave occurs almost immediately after the second wave. 
Controlled potential coulonetry of $\mathrm{TcO}_{4}^{-}$in neutral and acidic solutions indicates $4 \mathrm{e}^{-}$reduction proces at the potential of the first polarographic wave, whereas a $3 \mathrm{e}^{-}$reduction is uoually observed in base. 177 However, when phosphates or polyphosphates are present, reduction to $\mathrm{Tc}$ (II) species can occur owing to complex formation. 215 Mixed valence folywers of $\mathrm{Tc}(3.5)$ form by $\mathrm{SnCl}_{2}$ reduction of $\mathrm{TcO}_{4}^{-}$in $\mathrm{DTPA}^{-216}$

In noncomplexing media very little is known about aqueoue Tc(II) except that it is unstable. Arwatrong and Taube 217 reported formation of a pink traneient (several seconds) epecies formed by reduction or $\mathrm{TcO}_{4}^{-}$by $\mathrm{Eu}^{2+}$ in very acidic media. They attributed this color to unetable, and poseibly polyenic, Tc(II). Solid tate compound of Tc(I), Tc(II), and Tc(III) are well known. $9,194,218$ However, these valence atates are stabilized only when electron donating groups such as phosphine, nitrosyl, or thiocyanate are present. $\mathrm{K}_{2} \mathrm{TcI}_{3}$ was mentioned earlier, but it decomposes in aqueous solution.

Earlier, salt containing $\mathrm{Tc}_{2} \mathrm{Cl}_{8}^{3-}, \mathrm{Tc}_{2} \mathrm{Br}_{8}^{3-}, \mathrm{Tc}_{2} \mathrm{Cl}_{8}^{2-}$, $\mathrm{Tc}_{2} \mathrm{Br}_{8}^{2-}, \mathrm{Tc}_{2} \mathrm{Cl}_{6}^{2-}, \mathrm{Tc}_{2} \mathrm{Br}_{6}^{2-}, \mathrm{TcBr}_{2}$, and $\mathrm{TcI}_{2}$ were mentioned. They contain $\mathrm{Tc}$ with average formal valencies of $+2.5,+3$, or +2 . These salts can exist in concentrated aqueous hydrohalic acid solutions only under very reducing conditions. Of these lower valence states, only TC(III), appears to be a significant species for aqueous noncomplexing solutions. Russe11 176 has suggested that unstable $\mathrm{Tc}(\mathrm{I})$ and $\mathrm{Tc}(\mathrm{II})$ species could be involved in catalytic hydrogen evolution. Thus Tc(I) and Tc(II), if they fora, either rapidly reduce water or rapidly dieproportionate.

Salaria et $a 1.200$ found that $4 \mathrm{e}^{-}$coulonetric reduction of $\mathrm{TcO}_{4}^{-}$ occurred in $1 \mathrm{~mol} / 1 \mathrm{H}_{2} \mathrm{SO}_{4}(\mathrm{pH}=-0.3)$ and produced a black precipitate. However, in HC1-KCl mixtures at $\mathrm{pH}=1$ to 2 , a $4 \mathrm{e}^{-}$coulowatric reduction at -0.5 or $-0.3 \mathrm{~V}$ formed a green solution. Flsewhere, these authors reported 203 that suspended " $\mathrm{TCO}_{2}$ " could not be further reduced by varying the potential. However, if the initial reduction wa done at more negative potentials then a brown-black suspension of " $\mathrm{Tc}_{2} \mathrm{O}_{3}$ " was obtained. Rulf s et al. 147 reduced $\mathrm{TcO}_{4}^{-}$in $1=01 / 1 \mathrm{H}_{2} \mathrm{SO}_{4}$ coulonetrically below the +4 atate. But, when base was added, $\mathrm{TcO}_{2} \cdot 2 \mathrm{H}_{2} \mathrm{O}$ precipitated and not $\mathrm{Tc}_{2} \mathrm{O}_{3}$ 
Pihlar ${ }^{184}$ noted that solid, hydrolyzed Tc(III) could be TcO(OH), $\mathrm{Tc}(\mathrm{OH})_{3}$, or $\mathrm{Tc}_{2} \mathrm{O}_{3}$. To these possibilities can be added hydrates such as $\mathrm{Tc}_{2} \mathrm{O}_{3} \cdot \mathrm{H}_{2} \mathrm{O}, \mathrm{TcO}(\mathrm{OH}) \cdot \mathrm{H}_{2} \mathrm{O}$, etc. No enter what the chemical sate of the colid Tc(III) compounc, it ahould be equivalent to Gartledge's 78 $\mathrm{Tc}(\mathrm{OH})_{3}$ wich is reported in Table 2 .

If $\mathrm{TcO}_{4}^{-}$is reduced in $\mathrm{HCl}$ solutions by controlled potential reduction, at potentials that corresond to the firat polarographic reduction wave, the finel product is a green or yellow-green solution for $\mathrm{pH} \leq 3,200,205,206$ on the besis of coulonetry, these authors variously described the formel valence of reduced Tc as being either below 4, internadiate between 3 and 4 , or equul to +3 ,

In $\mathrm{NariSO}_{4}-\mathrm{Na}_{2} \mathrm{SO}_{4}$ mixtures, a pale yellow, reduced Tc species forms that probably containe $\mathrm{Tc}^{3+} \cdot 21$ Thus, the green color of $\mathrm{TC}$ (III) in BCl solutiona ma be due to technetiun chloride complexes rather than aquo ions. Arwatrong and Taube ${ }^{217}$ reported that potentionetric reduction of $\mathrm{TcO}_{4}^{-}$for initial $\left[\mathrm{H}^{+}\right]<1 \mathrm{~mol} / 1$ gave " $\mathrm{TcO}_{2}$ ", but "more extensive" reduction occurred when $\left[\mathrm{H}^{+}\right]=4 \mathrm{~mol} / 1$. Mrzocchin et al. 205 likewise obtained a yellowgreen solution by reduction of $\mathrm{TcO}_{4}^{-}$at $\mathrm{pH}<3$, but $\mathrm{TcO}_{2} \cdot 2 \mathrm{H}_{2} \mathrm{O}$ precipitated when $\mathrm{pH} \geq 3$. They suggeated, from their cyclic voltanetry atudy, that $\mathrm{Ts}_{2} \mathrm{~J}_{3} / \mathrm{TcO}_{2}$ mixtures form for $\mathrm{pH}<4$, but only $\mathrm{TcO}_{2}$ forms when $\mathrm{pH}>4$.

Grassi et al. ${ }^{21}$ reported that reducing $\mathrm{TcO}_{4}^{-}$in $\mathrm{HaHSO}_{4}-\mathrm{H}_{2} \mathrm{SO}_{4}$ mixtures precipitated black material, presumab1y "TcO ${ }_{2}$ ", when the $\mathrm{pH}$ was increased above 4.5. They interpreted this as due to disproportionation of Tc(III) to fore " $\mathrm{TcO}_{2}$ " (and $\mathrm{Te}^{\circ}$ ?). Further support for this possibility cones from Paquette et al. 's study in $\mathrm{CF}_{3} \mathrm{SO}_{3} \mathrm{H}, 206$ in which disproportionation of $\mathrm{Tc}$ (III) occurred above $\mathrm{pH}=4$. In this sane $\mathrm{pH}$ region, $\mathrm{TcO}_{2} \cdot 2 \mathrm{H}_{2} \mathrm{O}$ precipitates from Tc(IV) solutions. Disproportionation could explain why Rulfe et al. 147 obtained $\mathrm{TCO}_{2} \cdot 2 \mathrm{H}_{2} \mathrm{O}$ when trying to precipitate Tc(III) with base. 
Tc(III) solutions are also very prone to oxidation to Tc(IV) both electrochemica1ly and by atmospheric oxygen. 20,21,206 In fact, reoxidation of $\mathrm{Tc}$ (III) or $\mathrm{Tc}(\mathrm{IV})$ to $\mathrm{TcO}_{4}^{-} \mathrm{can}$ be done under rather gentle conditions. However, no clearly defined polarographic oxidation wave usually occurs for Tc(III)/Tc(IV) since it is masked by the $\mathrm{Hg}$ oxidation wave in acidic solutions. There is also the possibility that $\mathrm{Tc}$ (III) and $\mathrm{TcO}_{4}^{-}$may react to form hydrated $\mathrm{TcO}_{2} \cdot 176$

IL has been krown for many years that aqueous Tc salts can be electrolyzed to the metal. Voltz and Holr ${ }^{34}$ did a detailed study of plating of metallic Tc from sulfuric acid solutions, and found that $\mathrm{Tc}^{\circ}$ could be obtained in high yield for a variety of conditions and pH values. However, addition of $\mathrm{H}_{2} \mathrm{O}_{2}$ was required to eliminate pertial formation of $\mathrm{TcO}_{2} \cdot 2 \mathrm{H}_{2} \mathrm{O}$. Love and Greendale ${ }^{219}$ suggested that a surface amalgam of Tc formed by polarographic reduction of $\mathrm{Tc}(\mathrm{III})$ at about $1.2 \mathrm{~V}$ in alkaline citrate solutions.

Salaria et al. 200,203 studied the reduction of $\mathrm{TcO}_{4}^{-}$in aqueous acidic chloride and sultate solutions. A pH-independent second-reduction wave occurred at $-0.69 \mathrm{~V}$ for $\mathrm{pH}$ values of 3.5 to well below $\mathrm{pH}=0$. The number of electrons invelsed could not be determined due to the proximity of a catalyiic hydrogen wave. The dropping mezcury electrode had a film which could be chemically extracted to yield Tc. They suggested this may be a thin film of technetium metal.

Rulfs et al. 204 investigated this "amalgam" in greater detail. They found that Tc powder digested in mercury at $300 \mathrm{~K}$ did not dissolve. Since Tc is a high melting solid and is probably coated with oxide, this insolubility is not very surpriaing. Reduction of $\mathrm{TeO}_{4}^{-}$in acidic snlutions by liquid Hg produced a Tc surface film, with small amounts of Tc inside the Hg drop. 
Centrifuging this mercury resulted in a 4-fold separation of the Tc. This is consistent with solid particles having radii between $10^{-6}$ and $10^{-5} \mathrm{~cm}$ dispersed in the $\mathrm{Hg}$. These particles could either be metallic Tc or a Tc amalgam insoluble in Hig.

Grassi et $\mathrm{al} .21,220$ have reinvestigated the reduction of $\mathrm{TcO}_{4}^{-}$in acidic solutions. Their results using clesaical polarography agreed with other workers. They suggested that the metallic film on the $\mathrm{Hg}$ drop may reduce the hydrogen over-voltage on $7 g_{g}$, thus allowing the catalytic hydrogen wave to appear once the reduction to $\mathrm{Tc}^{\circ}$ occura (note that it was also suggested that tranaient $T c(I)$ or $T c(I I)$ produces this effect ${ }^{176}$ ). Grassi et al.' s radiopolarographic study ${ }^{220}$ provided the first quantitative evidence thet $\mathrm{Tc}$ (III) reduction in acidic solutions is a $3 \mathrm{e}^{-}$ reduction to $\mathrm{Tc}^{\circ}$ (i.e. there is no hydride formation as in basic 8olutions). The ratio of the diffusion currents of the first two polarographic diffusion controlled reduction waves was $4 / 3$. Since the first wave is a $4 \mathrm{e}^{-}$reduction of $\mathrm{TcO}_{4}^{-}$to $\mathrm{Tc}$ (III), the second reduction wave should be a $3 \mathrm{e}^{-}$reduction to $\mathrm{Tc}^{\circ}$ (assuming similar diffusion coefficients). This measurement was made at $\mathrm{pH}=2.83$ where the catalytic hydrogen current is low enough to allow the diffusion current and half-wave potential to be measured for the second wave. These authors considered the fact they even got radiopolarograms to indicate $\mathrm{Tc}^{\circ}$ formation. Their data cannot distinguish metallic Tc Eormation from amelgam formation.

It thus appears that $\mathrm{Tc}$ (III) is reduced to $\mathrm{Tc}^{\circ}$ at $\approx-0.6$ to $-0.7 \mathrm{~V}$ in acidic noncomplexing media for $\mathrm{pH}$ values of 3.5 or lower. The lack of a pH-dependence below $\mathrm{pH}=3.5$ implies that unhydrolyzed $\mathrm{Tc}$ (III) is involved. That is, the reaction is

$$
\begin{aligned}
\mathrm{Tc}^{3+}+3 \mathrm{e}^{-} & =\mathrm{Tc}^{\circ}(\mathrm{in} \mathrm{Hg}) . \\
& -51-
\end{aligned}
$$


Unfortunatel.y, it is not known whether this Tc is present as small wetallic particles in the $\mathrm{Hg}$ or as an insoluble $\mathrm{Tc}$ amalgam.

Rulfs et al. 204 studied the polarographic reduction of $\mathrm{TcO}_{4}^{-}$in deaerated solutions of $\mathrm{HClO}_{4}-\mathrm{NaClO}_{4}$. The second polarographic reduction occurred at -0.34 to $-0.49 \mathrm{~V}$ with the potential becoming more negative with increasing $\mathrm{pH}$. They suggested that this $\mathrm{pH}$ dependence may be due to variations in the amount of prereduction of $\mathrm{TcO}_{4}^{-}$by mercury. This prereduction by $\mathrm{Hg}$ may have effected Colton et al. ' 53 results also. It is also possible that the $\mathrm{HClO}_{4}$ may have partially reoxidized Tc(III) in Rulfa et al.'s study, ${ }^{204}$ since Grassi et al. 21 found that it can occur.

Salaria et al. 203 did the same type of polarographic reduction in 0.4-0.5 mol/1 HC1-KCl and 0.25-0.4 mol/1 $\mathrm{H}_{2} \mathrm{SO}_{4}-\mathrm{K}_{2} \mathrm{SO}_{4}$ mixtures. For $\mathrm{pH}$ values of $x-1$ to +3.5 , the second reduction wave occurred at half-wave potential of $-0.69 \mathrm{~V}$. This wave was irreversible but diffusion 1 imited. Since the same potential was obtained in sulfate and in chloride containing media, and at different ionic strengths, neither complex formation or ionic strength has a significant effect on it.

Russe11 and Cash 177 also found the second polarographic reduction wave to be pH-independent from $\mathrm{pH}=1$ to 4.8 ( $\mathrm{HClO}_{4}$, sulfate, phosphate, citrate, DTPA, ascorbate, and acetate were used to vary $\mathrm{pH}$ ). They thought that the reduction was probably a $7 \mathrm{e}^{-}$reduction to the metal. However, since the reduction potential was $-0.70 \pm 0.04 \mathrm{~V}$ and independent of $\mathrm{pH}$, it more likely corresponds to the $3 \mathrm{e}^{-}$reduction of $\mathrm{Tc}^{3+}$ to the metal.

Grassi et al. ${ }^{220}$ studied the second reduction wave of $\mathrm{TcO}_{4}^{-}$by both classical and radiopolarography. The half-wave potential was hard to determine by classical polarography owing to the near proximity of the calalytic hydrogen discharge wave. However, at $\mathrm{pH}=2.83 \mathrm{in} 0.5 \mathrm{~mol} / 1 \mathrm{KCl}+$ 
HC1, the catalytic current was low enough to allow the half-wave potential to be estimated $96-0.66 \mathrm{~V}$. Radiopolarography gave $-0.62 \mathrm{~V}$ in the same media and it was independent of $\mathrm{pH}$ from 1 to 3. Nuch lower concentrations of Tc are used in the radiopolarography measurements than in classical polarography. The "best-value" for the reduction potential of

$$
\mathrm{Tc}^{3+}+3 \mathrm{e}^{-}-\mathrm{Tc}^{\mathrm{o}}(\mathrm{in} \mathrm{Hg})
$$

is the average of $-0.668 \pm 0.036 \mathrm{~V}$. No attempt was made to extrapolate this potential to infinite dilution since the precision of its determination is not great enough to warrant it. This corresponds to a free energy of reaction of $\Delta G_{\text {rxn }}^{0}=193.4 \pm 10.4 \mathrm{~kJ} / \mathrm{mol}$. This can be related the free energy of formation of $\mathrm{Tc}^{3+}$ by

$\Delta G_{\mathrm{rxn}}^{0}=\Delta G_{\mathrm{f}}^{0}\left[\mathrm{Tc}^{0}\right.$ in $\left.\mathrm{Hg}\right]-\Delta G_{\mathrm{f}}^{0}\left[\mathrm{Tc}^{3+}(\mathrm{aq})\right]$

If the $\mathrm{Tc}^{\circ}$ exists as pure metal suspended in $\mathrm{Hg}$, then $\Delta \mathrm{G}_{\mathrm{f}}^{\mathrm{O}}\left[\mathrm{Tc}^{\circ}\right.$ in $\left.\mathrm{Hg}\right]=0$

and

$\Delta G_{\mathrm{f}}^{0}\left[\mathrm{Tc}^{3+}(\mathrm{aq})\right]=-\Delta G_{\mathrm{rXn}}^{0}=-193.4 \pm 10.4 \mathrm{~kJ} / \mathrm{mol}$

If, instead, the $\mathrm{Tc}^{\circ}$ is present as an amalgam, its free energy can be estimated assuming an ideal solution forms. The composition of this possibly hypothetical amalgam is unknown, but the maximum free energy of mixing expected is $-3.4 \mathrm{~kJ} / \mathrm{mol}$. Since we do not know whether an amalgam actually forms, we will just increase our uncertainty limit by half of that amount: $\Delta G_{\mathrm{f}}^{0}\left[\mathrm{Tc}^{3+}(\mathrm{aq})\right]=-193.4 \pm 12.1 \mathrm{~kJ} / \mathrm{mol}$.

Potential-pH diagram calculations were made by Dana Isherwood at this laboratory, using the data base obtained in this review. Using $\Delta \mathrm{G}_{\mathrm{f}}^{\mathrm{o}}\left[\mathrm{Tc}^{3+}(\mathrm{aq})\right]=-193.4 \pm 12.1 \mathrm{~kJ} / \mathrm{mol}$ leads to the incorrect prediction that $\mathrm{Tc}^{3+}$ is much more stable than the Tc(IV) species. 
This implies either that the second reduction wave for $\mathrm{TcO}_{4}^{-}$in acidic media has been misidentified, or that it does not yield valid thermodynamic results. In contrast (fortunately), the oxidation potentials for Tc(III) to Tc(IV) gives much more reasonable results. 21 Consequently, the reduction wave data were rejected, and oxidation wave resulta accepted instead.

Grassi et al. 21 studied the oxidation of Tc(III) to Tc(IV) in aqueous sulfate solutions between $\mathrm{pH}=1.6$ and 3.0 . This oxidation was quasi-reversible, and involved $1 \mathrm{e}^{-}$and $2 \mathrm{H}^{+}$ions. They noted that the following three reactions are consistent with this obervation:

$$
\begin{gathered}
\mathrm{Tc}^{3+}+\mathrm{H}_{2} \mathrm{O}=\mathrm{TeO}^{2+}+2 \mathrm{H}^{+}+\mathrm{e}^{-}, \\
\mathrm{Tc}(\mathrm{OH})^{2+}+\mathrm{H}_{2} \mathrm{O}=\mathrm{TcO}(\mathrm{OH})^{+}+2 \mathrm{H}^{+}+\mathrm{e}^{-},
\end{gathered}
$$

and

$$
\mathrm{TcO}^{+}+\mathrm{H}_{2} \mathrm{O}=\mathrm{TcO}_{2}+2 \mathrm{H}^{+}+\mathrm{e}^{-}:
$$

where " $\mathrm{TCO}_{2}$ " is equivalent to our $\mathrm{TcO}(\mathrm{OH})_{2}^{\circ}$ discussed earlier. They concluded, as here, that neutral soluble $\mathrm{TcO}_{2}\left[\mathrm{Or} \mathrm{TcO}_{2}(\mathrm{OH})_{2}\right.$ ] is the dominant atable species of Tc(IV) in this $\mathrm{pH}$ region. Since the polarographic oxidation potential varied linearly with $\mathrm{pH}$, only one Tc(III) and one Tc(IV) species should be present. Since " $\mathrm{TcO}_{2}$ " should be the $\mathrm{Tc}$ (IV) species present at equilibrium, they concluded the $\mathrm{Tc}$ (III) was present as $\mathrm{TcO}^{+}$ ions. In contrast, in this same $\mathrm{pH}$ region, reduction of $\mathrm{Tc}$ (III) to $\mathrm{Tc}^{\circ}$ led to the conflicting conclusion that $\mathrm{Tc}^{3+}$ was present as the dominant aqueous species.

We earlier concluded that reduction of $\mathrm{TcO}_{4}^{-}$may involve slow kinetics and that some reactions may not be seen on the polarographic time scale. The same situation may also occur for the oxidation of Tc(III). Both the oxidation and reduction behavior of $\mathrm{Tc}$ (III) in very acid solutions can be explained if $\mathrm{Tc}(\mathrm{III})$ is present as $\mathrm{Tc}^{3+}$. The polarographic oxidation then corresponds to

$$
\mathrm{Tc}^{3+}+\mathrm{H}_{2} \mathrm{O}=\mathrm{TcO}^{2+}+2 \mathrm{H}^{+}+\mathrm{e}^{-}
$$

and subsequent hydrolysis of $\mathrm{TcO}^{2+}$ to form $\left.\mathrm{TcO}^{2} \mathrm{OH}\right)^{+}$and $\mathrm{TcO}(\mathrm{OH})_{2}^{0}$ 
(or "TcO 2 ") would be too slow to be observed by polarography. Grasi et al. ' $\mathrm{s}^{21}$ half-wave reduction potential is $0.319 \mathrm{~V}$ under standard conditions. For reduction, $\Delta G_{\text {rxn }}^{0}=-30.8 \mathrm{~kJ} / \mathrm{mol}$. Using the coDATA value for $\mathrm{H}_{2} \mathrm{O}(1)$ and our evaluation for $\mathrm{TcO}^{2+}$, we obtain $\Delta G_{f}^{0}\left[\mathrm{Tc}^{3+}(\mathrm{aq})\right]=$ $105.8 \pm 10.5 \mathrm{~kJ} / \mathrm{mol}$. Potential-pH diagran calculationa by Dana Isherwood indicate that this value gives quite reasonable results, and it correctly predicts disproportionation of $\mathrm{Tc}^{3+}$ to $\mathrm{Tc}(\mathrm{CV})$ species for $\mathrm{pH} \geq 3$.

The first reduction wave for $\mathrm{TcO}_{4}^{-}$in acidic solutions is strongly $\mathrm{pH}$ dependent and irreversible. For very acid solutions, a $4 \mathrm{e}^{-}$reduction to Tc(III) can be observed (which becones $3 \mathrm{e}^{-}$at higher but still acidic pH value). Various reactione have been proposed for this wave. Rulfe et a 1.204 considered it to be due to

$$
\mathrm{TcO}_{4}^{-}+8 \mathrm{H}^{+}+4 \mathrm{e}^{-}=\mathrm{Tc}^{3+}+4 \mathrm{H}_{2} \mathrm{O}
$$

in perchlorate solutions. Alternate reduction achemes include Pihlar's 184

$$
\mathrm{TcO}_{4}^{-}+5 \mathrm{H}^{+}+4 \mathrm{e}^{-}=\mathrm{TcO}(\mathrm{OH})+2 \mathrm{H}_{2} \mathrm{O}
$$

with a rate determining step

$$
\mathrm{TcO}_{4}^{-}+2 \mathrm{H}^{+}+\mathrm{e}^{-}=\mathrm{TcO}_{3}+\mathrm{H}_{2} \mathrm{O}
$$

The large variation of the first reduction wave with $\mathrm{pH}$ is clearly seen in Russell and Cash's study. 177 Their half-wave potential varied as $\mathrm{E}=0.24$ $-0.10 \mathrm{pH}$ for $0<\mathrm{pH}<7$. They suggested that the rate-determining step was

$$
\mathrm{HTcO}_{4}+e^{-}=\mathrm{HTcO}_{4}^{-}
$$

Thus there is disagreement about both the rate determining-step and the reduction mechanism.

Reduction of $\mathrm{TcO}_{4}^{-}$to $\mathrm{Tc}^{3+}$ invalves stripping four oxygens from the $\mathrm{TcO}_{4}$ ion, and probably involves slow kinetics for several intermediate steps. Consequently, no attempt will be made to obtain thermodynamic data fron the firat reduction wave of $\mathrm{TcO}_{4}^{-}$in acidic media. 
These two polarographic reduction waves are seen in acidic solutions (below $\mathrm{pH}=4$ for the second wave). However, it should be noted in very concentrated strong acids (eg. 2 to $10 \mathrm{~mol} / 1 \mathrm{H}_{2} \mathrm{SO}_{4}, 4 \mathrm{~mol} / 1 \mathrm{HClO} / 4$, etc.) no well defined polarographic waves occur. $175^{2}$ Also, mercury oxidation becomes nore of a problem at these very low pH values.

There is no experiantal value for the

$$
\mathrm{Tc}^{2+}+2 \mathrm{e}^{-}=\mathrm{Tc}^{\circ}
$$

reduction potential owing to the thermodynamic instability of $\mathrm{Te}^{2+}$. We use the eatimated value of $0.40 \mathrm{~V}$ cited by Magee and Cardwe11, ${ }^{20}$ which is originally due to Latimer. Thi gives $\Delta G_{f}^{0}\left[\mathrm{Tc}^{2+}(\mathrm{aq})\right]=77.2 \mathrm{KJ} / \mathrm{misl}$. The reaction

$$
3 \mathrm{Tc}^{2+}=2 \mathrm{Tc}^{3+}+\mathrm{Tc}^{0}
$$

will then have a free energy change of $20 \mathrm{~kJ} / \mathrm{mol}$ and an equilibrium constant of

$$
k_{e q}=\frac{\left[\mathrm{Tc}^{3+}\right]^{2}\left[\mathrm{Tc}^{0}\right]}{\left[\mathrm{Tc} c^{2+}\right]^{3}}=\frac{\left[\mathrm{Tc}^{3+}\right]^{2}}{\left[\mathrm{Tc^{2+ }}\right]^{3}}=3 \times 10^{3}
$$

This indicates that the disproportionation of $\mathrm{Tc}^{2+}$ is favorable, and it is consistent with the lack of experimental evidence for this species.

Unfortunately, potential-pH diagram calculations with this value also predict that $\mathrm{Tc}^{2+}$ is more stable than $\mathrm{Tc}$ (IV) over a wide range of potential values. This conflicts with experimental results. Consequently, $\Delta G_{f}^{0}\left(\mathrm{Tc}^{2+}\right)$ is not included with the recommended results, and Latimer's estimated potential is probably somewhat in error.

Table 5 contains a summary of thermodynamic data for aqueous $T$ is species. Table 6 contains standard reduction potentials for a variety of aqueous redox couples calculated from these data. The third figure past the decimal point is not significant in most cases. 
TABLE 5. Thermodynamic data for aqueous Tc apecies at $298 \mathrm{~K}$.

Species $\Delta G_{\mathrm{f}}^{0}$ in $\mathrm{KJ} / \mathrm{mol} \quad \Delta \mathrm{H}_{\mathrm{f}}^{\mathrm{O}}$ in $\mathrm{KJ} / \mathrm{mol} \quad \mathrm{S}^{0}$ in $\mathrm{J} / \mathrm{mol}-\mathrm{K}$

\begin{tabular}{|c|c|c|c|}
\hline $\mathrm{TcO}_{4}^{-}$ & $-621.1 \pm 10.0$ & $-716.3 \pm 4.5$ & $199.0 \pm 1.3$ \\
\hline $\mathrm{TcO}_{4}^{2-}$ & $-562.2 \pm 10.0$ & -- & - \\
\hline $\mathrm{HTCO}_{4}^{-}$ & $-611.9 \pm 10.5$ & $-\infty$ & $-\infty$ \\
\hline $\mathrm{H}_{2} \mathrm{TcO}_{4}^{\circ}$ & $-613.6 \pm 12.1$ & - & - \\
\hline $\mathrm{TcO}_{4}^{3-}$ & $-505.3 \pm 11.2$ & - & - \\
\hline $\mathrm{TcO}^{2+}$ & $-100.6 \pm 10.5$ & - & - \\
\hline $\left.\mathrm{TcO}^{\mathrm{OOH}}\right)^{+}$ & $-331.3 \pm 10.5$ & -- & -- \\
\hline $\operatorname{TcO}(\mathrm{OH})_{2}^{\circ}$ & $-556.0 \pm 10.5$ & -- & - \\
\hline$\left[\mathrm{TcO}(\mathrm{OH})_{2}^{\circ}\right]_{2}$ & $-1149.2 \pm 21.3$ & - & $-\infty$ \\
\hline $\mathrm{Tc}^{3+}$ & $+105.8 \pm 10.5$ & -- & - \\
\hline
\end{tabular}

Reduction of $\mathrm{TcO}_{4}^{-}$by Aqueous Hydrohalic Acids, and the Hydrolysis of $\mathrm{TcCl}_{6}^{2-}$ and $\mathrm{TcBr}_{6}^{2-}$ Ions

In an earlier section, various oxyhalide salts were discussed that have 
TABLE 6. Standard aqueous reduction potentials for Tc.

$$
\begin{aligned}
& \mathrm{TcO}_{4}^{-}+\mathrm{e}^{-}=\mathrm{TcO}_{4}^{2-} \\
& -0.610 \\
& \mathrm{TcO}_{4}^{-}+2 \mathrm{e}^{-}=\mathrm{TcO}_{4}^{3-} \\
& -0.600 \\
& \mathrm{TcO}_{4}^{-}+\mathrm{H}^{+}+\mathrm{e}^{-}=\mathrm{HTCO}_{4}^{-} \\
& -0.095 \\
& \mathrm{TcO}_{4}^{-}+2 \mathrm{H}^{+}+\mathrm{e}^{-}=\mathrm{H}_{2} \mathrm{TcO}_{4}^{\circ} \\
& \mathrm{TcO}_{4}^{-}+8 \mathrm{H}^{+}+7 \mathrm{e}^{-}=\mathrm{Tc}(\mathrm{c})+4 \mathrm{H}_{2} \mathrm{O} \\
& \mathrm{TcO}_{4}^{-}+6 \mathrm{H}^{+}+3 \mathrm{e}^{-}=\mathrm{TcO}^{2+}+3 \mathrm{H}_{2} \mathrm{O} \\
& \mathrm{TcO}_{4}^{-}+5 \mathrm{H}^{+}+3 \mathrm{e}^{-}=\mathrm{TcO}(\mathrm{OH})^{+}+2 \mathrm{H}_{2} \mathrm{O} \\
& \mathrm{TcO}_{4}^{-}+4 \mathrm{H}^{+}+3 \mathrm{e}^{-}=\mathrm{TcO}(\mathrm{OH})_{2}^{\circ}+\mathrm{H}_{2} \mathrm{O} \\
& \mathrm{TcO}_{4}^{-}+3 \mathrm{H}_{2} \mathrm{O}+3 \mathrm{e}^{-}=\mathrm{TcO}^{2+}+6 \mathrm{OH}^{-} \\
& \mathrm{TcO}_{4}^{-}+3 \mathrm{H}_{2} \mathrm{O}+3 \mathrm{e}^{-}=\mathrm{TcO}(\mathrm{OH})^{+}+5 \mathrm{OH}^{-} \\
& \mathrm{TcO}_{4}^{-}+3 \mathrm{H}_{2} \mathrm{O}+3 \mathrm{e}^{-}=\mathrm{TcO}(\mathrm{OH})_{2}^{\mathrm{O}}+4 \mathrm{OH}^{-} \\
& -0.078 \\
& +0.485 \\
& +0.660 \\
& +0.638 \\
& +0.595 \\
& -0.995 \\
& -0.742 \\
& -0.509 \\
& \mathrm{TcO}_{4}^{-}+4 \mathrm{H}_{2} \mathrm{O}+4 \mathrm{e}^{-}=\mathrm{Tc}^{3+}+8 \mathrm{OH}^{-} \\
& \mathrm{TcO}_{4}^{3-}+3 \mathrm{H}_{2} \mathrm{O}+\mathrm{e}^{-}=\mathrm{TcO}^{2+}+6 \mathrm{H}^{-} \\
& \mathrm{TcC}_{4}^{3-}+6 \mathrm{H}^{+}+\mathrm{e}^{-}=\mathrm{TcO}^{2+}+3 \mathrm{H}_{2} \mathrm{O} \\
& \mathrm{TcO}^{2+}+2 \mathrm{H}^{+}+\mathrm{e}^{-}=\mathrm{Tc}^{3+}+\mathrm{H}_{2} \mathrm{O} \\
& \mathrm{Tc}^{3+}+3 \mathrm{e}^{-}=\mathrm{Tc}(\mathrm{c}) \\
& \mathrm{TCO}(\mathrm{OH})^{+}+3 \mathrm{H}^{+}+\mathrm{e}^{-}=\mathrm{Tc}^{3+}+2 \mathrm{H}_{2} \mathrm{O} \\
& \mathrm{TcO}(\mathrm{OH})_{2}^{\mathrm{O}}+4 \mathrm{H}^{+}+\mathrm{e}^{-}=\mathrm{Tc}^{3+}+3 \mathrm{H}_{2} \mathrm{O} \\
& \mathrm{TcO}_{4}^{-}+4 \mathrm{H}^{+}+3 \mathrm{e}^{-}=1 / 2\left[\mathrm{TcO}(\mathrm{OH})_{2}^{\circ}\right]_{2}+\mathrm{H}_{2} \mathrm{O} \\
& \mathrm{TcCl}_{6}^{2-}+\mathrm{H}_{2} \mathrm{O}+\mathrm{e}^{-}=\mathrm{Tc}(\mathrm{OH}) \mathrm{Cl}_{5}^{3-}+\mathrm{Cl}^{-}+\mathrm{H}^{+} \\
& \mathrm{TcBr}_{6}^{2-}+\mathrm{H}_{2} \mathrm{O}+\mathrm{e}^{-}=\mathrm{Tc}(\mathrm{OH}) \mathrm{Br}_{5}^{3-}+\mathrm{Br}^{-}+\mathrm{H}^{+} \\
& -1.080 \\
& -1.785 \\
& +3.181 \\
& +0.319 \\
& +0.366 \\
& +0.387 \\
& +0.516 \\
& +0.659 \\
& -0.233 \\
& -0.304
\end{aligned}
$$


been isolated and characterized in crystalline forms. These salts contain the anions $\mathrm{TcOCl}_{4}^{-}, \mathrm{TcOCl}_{5}^{2-}, \mathrm{TcOBr}_{4}^{-}, \mathrm{TcOBr}_{5}^{2-}$, or $\mathrm{TcOI}_{4^{-}}^{-}$All contain $\mathrm{Tc}$ in the unstable pentavalent form. The chloride and bromide salts are usually formed by direct reduction of $\mathrm{TCO}_{4}^{-}$by $\mathrm{HCl}$ or $\mathrm{HBr}$, whereas the iodide salt is usually obtained by ligend exchange with chloride salts. This section is concerned with the reduction of $\mathrm{TcO}_{4}^{-}$by hydrohalic acids, and the ultimate "thermodynamic fate" of Tc in these solutions.

Reduction of $\mathrm{TcO}_{4}^{-}$by aqueous $\mathrm{HCl}$ seeme to occur at all $\mathrm{HCl}$ concentrations, with the reduction being very slow at low HCl concentrations and very fast at high HCl concentrations. At HC1 concentrations of about 5 mo1/1 and above, reduction is extensive and rapid. Below ab ut $5 \mathrm{~mol} / 1$, the reaction rate drops rapidiy with decreasing HCl concentration. Increasing the temperature increases the rate at which $\mathrm{TcO}_{4}^{-}$is reduced. The effects of concentration and temperature are discussed by a number of workers. ${ }^{221-229}$ It is worth noting that ${ }^{99} \mathrm{mc}$ is reduced more rapidly than ${ }^{99} \mathrm{Tc}$ by aqueous HC1. 227

Most of these studies of reduction of $\mathrm{TCO}_{4}^{-}$by $\mathrm{HCl}$ and $\mathrm{HBr}$ involved the separation and identification of various Tc valence states by chromatography. It is generally accepted that $\mathrm{TcO}_{4}^{-}$is initially reduced to $\mathrm{Tc}(\mathrm{V})$ oxyhalides, followed by a much slower reduction to $\mathrm{Tc}$ (IV) in the form of $\mathrm{Tcx}_{6}^{2-}$. For example, reduction of $\mathrm{TcO}_{4}^{-}$by concentrated $\mathrm{HCl}$ to $\mathrm{Tc}(V)$ is nearly instantaneous at room temperature, hyt aging for 2 years was required to obtain "chromatographically pure" $\operatorname{TcCl}_{6}^{2-}$. However, at $373 \mathrm{~K}$, Cifka ${ }^{228}$ reported that $11.4 \mathrm{~mol} / 1 \mathrm{HCl}$ reduced $\mathrm{TcO}_{4}^{-}$to $\mathrm{TeCl}_{6}^{2-}$ in 10 minutes. In contrast, Ossicini et $a .^{221}$ found some $\mathrm{Tc}(\mathrm{V})$ remained after 4 hours heating at this temperature (but no $\mathrm{TcO}_{4}^{-}$was left). Reduction of $\mathrm{TcO}_{4}^{-}$by $\mathrm{HBr}$ is more rapid than by $\mathrm{HCl}$. Ossicini et a1. 221 found that concentrated $\mathrm{HBr}$ rapidly reduced $\mathrm{TcO}_{4}^{-}$to $\mathrm{Tc}(v)$ at room temperature, and that all $\mathrm{TcO}_{4}^{-}$was converted to $\mathrm{Tc}$ (IV) within one day. At lower concentrations the reduction is considerably slower. However, at $373 \mathrm{~K}$, less than 30 minutes of heating converts all $\mathrm{TcO}_{4}^{-}$to $\mathrm{TCBr}_{6}^{2-}$ in concentrated $\mathrm{HBr}$.

Shuk $1 \mathrm{a}^{224}$ studied the reduction of $\mathrm{TcO}_{4}^{-}$in $7 \mathrm{~mol} / 1 \mathrm{HCl}$. Reduction to $\mathrm{Tc}(V)$ was conpiete after 2 hours, but less than $177 \mathrm{Tc}$ (IV) was present even after 50 days. However, when small amounts of $\mathrm{Br}^{-}$were added to these solutions, reduction to $\mathrm{Tc}(\mathrm{V})$ was complete within 45 minutes and was followed 
by reduction to pure TC(IV) within 3 days. This increased reduction rate by $\mathrm{Br}^{-}$is in agreement with relative reduction rates in pure $\mathrm{BCl}$ and $\mathrm{HBr}$ solutions. ${ }^{221}$ Shuk1 $a^{224}$ also found that adding $\mathrm{I}^{-}$to the $7 \mathrm{~mol} / \mathrm{l} \mathrm{HCl}$ caused instantaneous reduction to $\mathrm{Tc}$ (IV). However, this $\mathrm{Tc}$ (IV) could be $\mathrm{Tc}(\mathrm{OH}) \mathrm{Cl}_{5}^{2-}$ rather than $\mathrm{TCCl}_{6}^{2-}$ when $\mathrm{I}^{-}$reduction is used. 157

These obeervatione explain why thermodynamically unstable Tc(v) oxyhalidea can be prepared by the direct reduction of $\mathrm{TcO}_{4}^{-}$by $\mathrm{HCl}$ or HBr. 152-159 Conditions can be chosen to give high yields of $\mathrm{Tc}(v)$ since the further reduction to $\mathrm{Tc}$ (IV) is usually much elower. It is also clear that the ultimate "therwodynamic fate" of Tc(v) oxyhalides left in hydrohalic acid solutions is to be converted into $\mathrm{TcX}_{6}^{2-}\left(\mathrm{X}=\mathrm{Cl}^{-}\right.$or $\left.\mathrm{Br}^{-}\right)$eince the yield of $\mathrm{Tc}$ (IV) generally increases with time. However, HI reduces $\mathrm{TcO}_{4}^{-}$ directly to $\mathrm{TcI}_{6}^{2-}$ urder most conditions. Consequently, ligand exchange of $\mathrm{I}^{-}$with $\mathrm{TcOCl}_{4}^{-}$or $\mathrm{TcOBr}_{4}^{-}$in neutral nonaqueous solution is the favored synthesis route for $\mathrm{TCOI}_{4}^{-}$.

The formation of TC oxyhalides in HCl or $\mathrm{HBr}$ occurs by the net reactions

$$
\mathrm{TcO}_{4}^{-}+6 \mathrm{HX}=\mathrm{TcOX}_{4}^{-}+3 \mathrm{H}_{2} \mathrm{O}+\mathrm{X}_{2}
$$

or

$$
\mathrm{TcO}_{4}^{-}+7 \mathrm{HX}=\mathrm{TcOX}_{5}^{2-}+3 \mathrm{H}_{2} \mathrm{O}+\mathrm{X}_{2}+\mathrm{H}^{+}
$$

Thus, increased reaction rates in more concentrated $\mathrm{HX}$ solutions are expected since both halide and hydrogen ion participate in the reaction. Shukle ${ }^{223}$ studied the reduction of $\mathrm{TCO}_{4}^{-}$by $\mathrm{HCl}-\mathrm{LiCl}$ mixtures at a total chloride concentration of $12 \mathrm{~mol} / 1$. If $\left[\mathrm{H}^{+}\right]=12$, then reduction of $\mathrm{TcO}_{4}^{-}$to $\mathrm{Tc}(V)$ is instanteneous. For $\left[\mathrm{H}^{+}\right]=7$ and $\left[\mathrm{Li}^{+}\right]=5$, two hours were required. The reduction time increased to 7 hours for $\left[\mathrm{ii}^{+}\right]=6$ and $\left[\mathrm{Li}^{+}\right]=6$. For $\left[\mathrm{H}^{+}\right]=2$ and $\left[\mathrm{Li}^{+}\right]=10$, reduction to $\mathrm{TC}(\mathrm{V})$ was not complete even after 50 days. This indicates that otripping of one or wore oxygen atons fron $\mathrm{TcO}_{4}^{-}$must occur before $\mathrm{X}^{-}$will produce reduction, and that reduction is quite slow except at very high acidities. Rajec et a1. 193 reported that $\operatorname{TcOCl}_{n}^{-n+3}$ is otrongly hydrolyzed if $\left[\mathrm{H}^{+}\right]<3.15 \mathrm{~mol} / 1$. They also reported that if $\left[\mathrm{CI}^{-}\right]<5$, then the 
oxyhalide solution was more senaitive to oxidation. Liquid extraction experiments showed that $\mathrm{TCOCl}_{5}^{2-}$ dominated when $\left[\mathrm{Cl}^{-}\right]=6$ and $3.15<$ $\left[\mathrm{H}^{+}\right]<6$. However, when $5<\left[\mathrm{Cl}^{-}\right]<6$ several different $\operatorname{TcOCI}_{\mathrm{n}}^{-\mathrm{n}+3}$ species were present.

Rajec and Macsesk ${ }^{230}$ studied the electrochemical reduction of $\operatorname{TcOCl}_{5}^{2-}$ in 4 wol/1 HCl. They poutulated the mechanien

$$
\operatorname{TrOCl}_{5}^{2-}+2 \mathrm{H}^{+}+-^{-}=\mathrm{Tc}\left(\mathrm{H}_{2} \mathrm{O}\right) \mathrm{Cl}_{5}^{-}
$$

followed by

$$
\mathrm{Tc}\left(\mathrm{H}_{2} \mathrm{O}\right) \mathrm{Cl}_{5}^{-}+\mathrm{Cl}^{-}=\mathrm{TcCl}_{6}^{2-}+\mathrm{H}_{2} \mathrm{O}
$$

However, some direct reaction

$$
\mathrm{TcOCl}_{5}^{2-}+2 \mathrm{H}^{+}+\mathrm{Cl}^{-}+\mathrm{e}^{-}=\mathrm{TcCl}_{6}^{2-}+\mathrm{H}_{2} \mathrm{O}
$$

could also have occurred. Thus, electrolytic reduction of $\mathrm{Tc}(\mathrm{V})$ oxyhalides produces $\mathrm{TcX}_{6}^{2-}$ as does reduction of $\mathrm{TcO}_{4}^{-}$by $\mathrm{HX}$. However, the electrode catalyzed reduction of $\mathrm{Tc}(V)$ is more rapid.

There is one clain that $\mathrm{Tc}(\mathrm{V})$ is not formed as an interwediate species, ${ }^{229}$ but that hydrolyzed $\mathrm{TCCl}_{6}^{2-}$ species occur instead. The above discussion, and the isolation of salts of the type $\operatorname{TcOx}_{n}^{-3+n}$, leave little doubt that this speculation is incorrect.

Noll and Muinze ${ }^{226}$ studied the reduction of $\mathrm{TcO}_{4}^{-}$by $\mathrm{HCl}$ and suggested that " "lower" oxidation state of Tc forms initally, which then reacts with $\mathrm{TcO}_{4}^{-}$to produce the $\mathrm{Tc}(V)$ oxyhalicis. They also clained that $\mathrm{Tc}$ (IV) species and $\mathrm{TcO}_{4}^{-}$then form by disproportionation of $\mathrm{Tc}(v)$. If so, this is the same type of disproportionation that occurs in noncomplexing (halide free) solutions.

Since chemical reduction is involved in these reactions, other chenical species can effect the kinetics. Cifka ${ }^{228}$ found that ferric chloride and ascorbic acid increased the $\mathrm{TsO}_{4}^{-}$reduction rate. $\mathrm{SnCl}_{2}$, which is a reducing agent, reduces $\mathrm{TcO}_{4}^{-}$in $\mathrm{HCl}$ directly to $\mathrm{TC}(\mathrm{IV}) .^{216}$ Shukla $^{223}$ studied the $\mathrm{HCl}$ reduction of $\mathrm{TcO}_{4}^{-}$at constant $\left[\mathrm{B}^{+}\right]$. Adding LiCl to the solution increased the reduction rate, but NaCl slowed it down. 
$\mathrm{TcX}_{6}^{2-}$ is wore reoistant to oxidation than wost $\mathrm{Tc}$ (IV) oxy-species, but it can be reoxidized to $\mathrm{TcO}_{4}^{-}$. Shukle 231 found that excess $\mathrm{H}_{2} \mathrm{O}_{2}$ oxidizea $\mathrm{TcCl}_{6}^{2-}$ directly to $\mathrm{TcO}_{4}^{-}$, wheras $\mathrm{Cl}_{2}$ oxidation produces $\mathrm{Tc}(\mathrm{V})$ firat and $\mathrm{TcO}_{4}^{-}$later. Atwosheric $\mathrm{O}_{2}$, even in the presence of ounlight, caused no oxidation. However, Gifka ${ }^{228}$ found that $\mathrm{TcCl}_{6}^{2-}$ was leas atable with regard to oxidation above $\mathrm{pH}=4$. Most strong oxiding agents such as $\mathrm{HHO}_{3}, \mathrm{MnO}_{4}^{-}$, and $\mathrm{Ce}^{4+}$ oxidive $\mathrm{TcX}_{6}^{2-}$ to $\mathrm{TcO}_{4}^{-}$

While $\mathrm{TcX}_{6}^{2-}$ apecies are atable in concentrated hydrohalic acid solutions, hydrolyais can occur as the ph is incrased, Osaicini et al, 221 atudied the hydrolyais of $\mathrm{TcCl}_{6}^{2-}$ and $\mathrm{TcBr}_{6}^{2-}$ in the corresponding hydrohalic acids at $\approx 1$ mol/1 acid. They concluded that $\mathrm{TcCl}_{6}^{2-}$ wes much wore stable with regard to hydrolysis than $\mathrm{TCBr}_{6}^{2-}$. In agreer ent with this, Schwochau 232 found the etep wise formation constant for

$$
\operatorname{Tc}\left(\mathrm{H}_{2} \mathrm{O}\right) \mathrm{X}_{5}^{-}+\mathrm{X}^{-}=\mathrm{TcX}_{6}^{2-}+\mathrm{H}_{2} \mathrm{O}
$$

was about a factor of 20 larger for $\mathrm{X}=\mathrm{Cl}^{-}$than for $\mathrm{X}=\mathrm{Br}^{-}$. The $\mathrm{TCF}_{6}^{2-}$ ion is even lese prone to hydrolysis. ${ }^{221}$ If I- follow the same trend, then stability to hydrolysis followe the vider $\operatorname{TcF}_{6}^{2-}$; $\operatorname{TcCl}_{6}^{2-}>\operatorname{TcBr}_{6}^{2-}>\operatorname{TcI}_{6}^{2-}$. Hydrolysis of $\operatorname{TcCl}_{6}^{2-}$ will be discussed in more detail since several studies of it have been published. $\mathrm{TcCl}_{6}^{2-}$ solutions are reported to be very otable with regard to hydrolyais when stored in the derk. 207,208 This is true no antter what HCl concentration they are dissolved $i n,{ }^{233}$ or whether the $\operatorname{TcCl}_{6}^{2-}$ is in $\mathrm{HClO}_{4}{ }^{-208}$ This is true for $\operatorname{TcCl}_{6}^{2-}$ up to $\mathrm{pH}=7,227$ but in basic solution hydrolysis is clained to be rapid. ${ }^{175}$ Friedman's article 175 provides useful background information.

Koyama et a1., 207 Kanchiku, ${ }^{208}$ Fujinaga et $21 .,^{233}$ and Kawashima et al. 234 have studied hydrolysis of $\operatorname{TcCl}_{6}^{2-}$ (and to a leser extent $\operatorname{TcBr}_{6}^{2-}$ ) in some detail. Spectra of solutions in HC1, stored in the dark, showed no change with time. When irradiated with UV or visib:e 1ight, however, the apectra changed with tiwe but gradually approached equilibriu. Ion-exchange separation yielded anionic, neutral, and cationic peaks whose 
amounts depencied on irradiation time and $\mathrm{HC} i$ concentration during the irradiation. One peak corresponded to a $\mathrm{Cl}^{-} / \mathrm{Tc}^{4+}$ ratio of $6: 1$ and had a

charge of $=-2$; this was obviously unhydrolyzed $\operatorname{TcCl}_{6}^{2-} 207,208$ Another peak had $\mathrm{Cl}^{-} / \mathrm{Tc}^{4+}$ ratio of $5: 1$ and a charge of $*-1$; this was clearly $\mathrm{Tc}_{2}\left(\mathrm{H}_{2} \mathrm{O}\right) \mathrm{Cl}_{5}^{-} \cdot 207,208$ Two other peaks were found with charges of zero and $*+1,306$ These could have been $\mathrm{Tc}_{2}\left(\mathrm{H}_{2} \mathrm{O}\right) \mathrm{Cl}_{4}^{\circ}$ and $\mathrm{Tc}\left(\mathrm{H}_{2} \mathrm{O}\right)_{2} \mathrm{Cl}_{3}^{+}$. However, they were not ctable enough to renove froi the ion-exchange colun for $\mathrm{Cl}^{-}$analyeis, so the $\mathrm{Cl}^{-} / \mathrm{Tc}^{4+}$ ratios are unknown. If these experiments were repeated with radioactive $\mathrm{Cl}^{-}$ions, then both $\mathrm{Cl}^{-}$and $\mathrm{Tc}^{4+}$ could be deternined simultaneously for them. Kawashima et al. 234 likevise separated ions wi.th $\mathrm{Br}^{-} / \mathrm{Tc}^{4+}$ ratio of $6: 1$ and $5: 1$, presunably $\operatorname{TcBr}_{6}^{2-}$ and $I:\left(\mathrm{H}_{2} \mathrm{O}\right) \mathrm{Br}_{5}^{-}$, fron hydrolyzed $\operatorname{TcBr}_{6}^{2-}$. They also studyed the hydrolysis ininetics of $\mathrm{TcCl}_{6}^{2-}$ and $\operatorname{TcBr}_{6}^{2-}$ and found aquation rates to be firat order both in $\mathrm{X}^{-}$and $\mathrm{H}^{+}$. Identification of the neutral and cationic species was tentative aince the $\mathrm{Cl}^{-} / \mathrm{Tc}^{4+}$ ratios could not be measured for them. other speciea could fit the same description, eg. $\mathrm{Tc}\left(\mathrm{H}_{2} \mathrm{O}\right)(\mathrm{O} i \mathrm{i}) \mathrm{Cl}_{3}^{\circ}$ and $\mathrm{Tc}\left(\mathrm{H}_{2} \mathrm{O}\right)_{2}(\mathrm{OH}) \mathrm{Cl}_{2}^{+}$. This possibility was noted by Koyane et al. 207 Both $\operatorname{TcCl}_{6}^{2-}$ and $\operatorname{Tc}\left(\mathrm{H}_{2} \mathrm{O}\right) \mathrm{Cl}_{5}^{-}$are yellow. However, if $\mathrm{pH}>1$, then the $\mathrm{Tc}\left(\mathrm{H}_{2} \mathrm{O}\right) \mathrm{Cl}_{5}^{-}$solution became brown. They thought this could be due to the reaction

$$
\mathrm{Tc}\left(\mathrm{H}_{2} \mathrm{O}\right) \mathrm{Cl}_{5}^{-}=\mathrm{Tc}(\mathrm{OH}) \mathrm{Cl}_{5}^{2-}+\mathrm{H}^{+}
$$

Likewise the green neutral complex, preaumably $-:\left(\mathrm{H}_{2} \mathrm{O}\right)_{2} \mathrm{Cl}_{4}^{\circ}$, hydrolyzed to form a brown basic solution that eventually precipitated $\mathrm{TCO}_{2} \cdot 2 \mathrm{H}_{2} \mathrm{O}$. A similar brown color was reported for the uncharged hydrolysis product of $\mathrm{TeCl}_{6}^{2-}$ in aqueous $\mathrm{H}_{2} \mathrm{SO}_{4} \cdot 235$ Ianovici et a1. 235 did comparative hydrolysis studies of $\mathrm{TCCl}_{6}^{2-}$ in aqueous $\mathrm{HCl}$, $\mathrm{HClO}_{4}$, and $\mathrm{H}_{2} \mathrm{SO}_{4}$. 
Whereas $\operatorname{TcCl}_{6}^{2-}$ is resistant to oxidation, $\operatorname{Tc}\left(\mathrm{H}_{2} \mathrm{O}\right) \mathrm{Cl}_{5}^{-}$and $\mathrm{Tc}\left(\mathrm{H}_{2} \mathrm{O} \mathrm{Cl}_{4}^{\circ}\right.$ can be slowly oxidized by air to form $\mathrm{TcO}_{4}^{-} \cdot 207$

ranovici et al. 235 found that this oxidation was faster in $\mathrm{HClO}_{4}$ solutions than in HCl, but it was much slower in $\mathrm{H}_{2} \mathrm{SO}_{4^{-}}$Reduction of $\mathrm{TcX}_{6}^{2-}$ can occur electrolytically, and the $\mathrm{TcX}_{6}^{3-}$ formed reidily undergoes liganci substitution ${ }^{9}$ (however, most reduction studies obtain $\mathrm{Tc}(\mathrm{OH}) \mathrm{x}_{5}^{3-}$, see below).

The spectral characteristica of $\mathrm{TcCl}_{6}^{2-}$ in $\mathrm{HClO}_{4}$ and $\mathrm{H}_{2} \mathrm{SO}_{4}$ solutions do not depend on length of irradiation with light (but peak intensities do). ${ }^{235}$ Changes continue to occur in HCl solutions, suggesting that more than one cationic species may be present. Further evidence for this comes from the color of these solutions: hydrolyzed cationic Tc(IV) chloride is green in $\mathrm{HCl}$, brown in $\mathrm{HClO}_{4}$, and pink in $\mathrm{H}_{2} \mathrm{SO}_{4}$.

We earlier discussed haloditechnetate ions which can be isolated as crystalline salts: $\mathrm{Tc}_{2} \mathrm{Cl}_{8}^{3-}, \mathrm{Tc}_{2} \mathrm{Cl}_{8}^{2-}$, and $\mathrm{Tc}_{2} \mathrm{Br}_{8}^{2-} \cdot 125-138$

They exist only in recucing conditions and in fairly concentrated HCl or HBr. Hydrolysis of $\mathrm{Tc}_{2} \mathrm{Cl}_{8}^{3-}$ was claimed to give $\mathrm{Tc}_{4} \mathrm{O}_{5} \mathrm{mH}_{2} \mathrm{O}^{80}$ By analogy, hydrolysis of $\mathrm{Tc}_{2} \mathrm{Cl}_{8}^{2-}$ and $\mathrm{Tc}_{2} \mathrm{Br}_{8}^{2-}$ might yield $\mathrm{Tc}(\mathrm{OH})_{3}$ (or $\mathrm{Tc}_{2} \mathrm{O}_{3}$ ).

Cotton and Pedersen 236 found the reduction

$$
\left[\mathrm{Tc}_{2} \mathrm{Cl}_{8}\right]^{2-}+\mathrm{e}^{-}=\left[\mathrm{Tc}_{2} \mathrm{Cl}_{8}\right]^{3-}
$$

to be quasi-reversible in HCl-ethanol mixtures.

Thermodynamic Data for Aqueous Technetium Halide and Hydroxy-Halide Complexes

The stepwise association constant for

$$
\mathrm{Tc}\left(\mathrm{H}_{2} \mathrm{O}\right) \mathrm{X}_{5}^{-}+\mathrm{X}^{-}=\mathrm{TcX}_{6}^{2-}+\mathrm{H}_{2} \mathrm{O}
$$

with $\mathrm{X}=\mathrm{Cl}^{-}$or $\mathrm{Br}^{-}$, has been determined by several workers. The association constant is given by 
$K_{56}=\frac{\left[\mathrm{TcX}_{6}^{2-}\right]}{\left[\operatorname{Tc}\left(\mathrm{H}_{2} \mathrm{O}\right) \mathrm{x}_{5}^{-}\right]\left[\mathrm{X}^{\prime \prime}\right]}$

Since $\left[\mathrm{H}_{2} \mathrm{O}\right.$ ] varies little, it is absorbed into $\mathrm{K}_{56}$. Kawashima et al. ${ }^{234}$ scudied this equilibrium for $\mathrm{X}=\mathrm{Cl}^{-}$and $\mathrm{Br}^{-}$by measuring optical densities. The chloride salt was studied from 348 to $363 \mathrm{~K}$; the bromide salt from 313 to $328 \mathrm{~K}$. Rajac and Macášek ${ }^{230}$ obtained $\mathrm{K}_{56}=0.80 \pm 0.04$ ror the chloride at $298 \mathrm{~K}$ using nearly identical techrique. They extrapolated Kawashima et al.'s data to $298 \mathrm{~K}$ to obtain $\times 1.24$. Both studieo were in $4 \mathrm{~mol} / 1 \mathrm{HCl}$. The agreement is fair, and the "beat value" is the average of $1.0 \pm 0.2$ for chloride salts. Rajac and Macklyek noted that their results could be "steady state ratios" rather than $k_{56^{\circ}}$. Unfortunately, Schwochau"s potentiometric study in $3 \mathrm{~mol}_{1} 1 \mathrm{kClO}_{4}$ at $288 \mathrm{~K}$ yields $\mathrm{K}_{56}$ values for both chloride and bromide that differ by several orders of magnitude from the other two studies. 232

Another type of equilibria has been studied polarographically by various workers. It corresponds to

$$
\mathrm{TcX}_{6}^{2-}+\mathrm{H}_{2} \mathrm{O}(1)+\mathrm{e}^{-}=\mathrm{Tc}(\mathrm{OH}) \mathrm{X}_{5}^{3-}+\mathrm{X}^{-}+\mathrm{H}^{+},
$$

where $\mathrm{X}=\mathrm{Gl}^{-}$or $\mathrm{Br}^{-}, 186,202,237,238$ This $1 \mathrm{e}^{-}$reduction is reversible. 186,20?:238 Münze reported a reduction otential of about $-0.213 v$ for the chloride. ${ }^{202,238}$ whereas Hurat ${ }^{186}$ obtained a value of $-0.252 \mathrm{~V}$ for the chlortie and $-0.304 \mathrm{~V}$ for the bromide. These values are also listed in Table 6, and refer to $I=1$ to 4 for the chloride salt and $I=6$ for the bromide salt. No attempt will be made to extract free energies of formation from this data, or from values of $\mathrm{k}_{56}$ reported above, since they give only relative values.

Trop et $a 1 .^{239}$ have studied the oxidation

$$
\operatorname{TcX}_{6}^{2-}=\operatorname{Tcx}_{6}^{-}+e^{-}
$$

where $\mathrm{X}=\mathrm{C1}^{-}, \mathrm{Br}^{-}$, or $\mathrm{NCS}^{-}$. These oxidized species contain $\mathrm{Tc}(\mathrm{V})$ which is quite unstable in aqueous solution owing to its disproportionation to $\mathrm{Tc}$ (IV) and $\mathrm{Tc0}_{4^{-}}^{-}$Consequent $1 \mathrm{y}$, these workers did their electrochemical measurements in anhydrous acetonitrile. 
Aqueous Sulfate, Carbonate, Phosphate, Pyrophosphate, and Tripolyphosphate Complexes

Spitsyn et a1. 45 studied Tc(IV) in $\mathrm{H}_{2} \mathrm{SO}_{4}$ solutions and separated a brown, noncolloidal, anionic complex by electropheresig. Variation of ita spectra with pH suggested $\mathrm{Tc}(\mathrm{OH})_{2}\left(\mathrm{SO}_{4}\right)_{2}^{2-}$, which we shall write as TcO( $\left.\mathrm{SO}_{4}\right)_{2}^{2-}$ to maintain consistency with our other notation. This same conplex was invoked by Grassi et al. ${ }^{21}$ to explain some features of the reduction of $\mathrm{TeO}_{4}^{-}$in $\mathrm{Na}_{2} \mathrm{SO}_{4}-\mathrm{NaHSO}_{4}$ solutiona. If $\mathrm{TcO}\left(\mathrm{SO}_{4}\right)_{2}^{2-}$ can form at high sulfate concentrations, then $\mathrm{TcOSO}_{4}^{\circ}$ is possible at lower concentrations. No published thermodynamic data are available for either of these complexes.

Paquette et al. 16,206 have briefly discussed carbonate complexes of $\mathrm{Tc}$ (III) and $\mathrm{Tc}$ (IV). If $\left[\mathrm{CO}_{3}^{2-}\right] /\left[\mathrm{Tc}^{\mathrm{n}+}\right]>30$, then hydrolysis is suppressed and precipitation of $\mathrm{TcO}_{2} \cdot 2 \mathrm{H}_{2} \mathrm{O}$ eliminated. Also, Tc(III) is stabilized by these complexes, and does not disproportionate even up to $\mathrm{pH}=12$ (it disproportionates above $\mathrm{pH}=3$ to 4 in noncomplexing medis). Spectroscopic evidence also exists for these complexes, but neither their stoichiometry or thermodynamics have been measured.

Reduction of $\mathrm{TcO}_{4}^{-}$in aqueous $\mathrm{PO}_{4}^{3-}, \mathrm{P}_{2} \mathrm{O}_{7}^{4-}$, and $\mathrm{P}_{3} \mathrm{O}_{10}^{5-}$ gives evidence for a number of lower valence complexes. $195,215,240$ In phosphate solutions green Tc(III) and pink Tc(IV) form. A mixed valence Tc(III) - Tc(IV) complex, probably also containing $\mathrm{Sn}(\mathrm{II})$, is formed by the $\mathrm{SnCl}_{2}$ reduction of $\mathrm{TcO}_{4}^{-}$in phosphate solutions. Pyrophosphate solutions can contain light blue Tc(III), pink Tc(IV), and possibly yellowish Tc(II). In tripolyphosphate solutions, pink Tc(IV), orange Tc(IV) + Tc(III), and yellow Tc(III) complexes have been reported. For phosphate-buffered tripolyphosphate solutions, there are pink Tc(IV), gray Tc(IV) + Tc(III), and green Tc(III).

Several of these systems have reversible redox couples. Unfortunately, the nature and stoichionetry of the $\mathrm{PO}_{4}^{3-}, \mathrm{P}_{2} \mathrm{O}_{7}^{4-}$, and $\mathrm{P}_{3} \mathrm{O}_{10}^{5-}$ complexes with $\mathrm{Tc}$ (III) and $\mathrm{Tc}$ (IV) are unknown. Consequently, they cannot be used to 
calcuilate thermodynamic data. Friedman's ${ }^{175}$ literature survey contains more references and details.

\section{Brief Summary and Recommendations for Future Studies}

Thermodynamic and chemical data for Tc and many of its inorganic compounds and their aqueous solutions have been critically reviewed, Values for thermodynamic properties have been recommended when good meanurement: are available and the chemistry adequately understood.

A few general comments are in arder. In noncomplexing aqueous solutions, and for aimple inorgenic compounds, certain valence tates predominate. Under oxidizing conditions $\mathrm{Tc}(V I I)$ is stable (e.g. $\mathrm{Tc}_{2} \mathrm{O}_{7}, \mathrm{HTCO}_{4}, \mathrm{Tc}_{2} \mathrm{~S}_{7}, \mathrm{TeO}_{4}^{-}$ealts). Under moderately reducing conditions $T C$ (III) conpound can form, but they are generally sensitive to oxidation. $\mathrm{Tc}$ (IV) is the nost stable state under moderately reducing conditions. $T c(V)$ and $T c(V I)$ generally disporportionate to the other valence states.

Thermodynamic data are unavailable for a number of significant species and should be measured. Exanples includfe $\operatorname{TcCl}_{4}(c), \operatorname{TcCl}_{6}(c), \operatorname{TcBr}_{4}(c)$, $\mathrm{TcO}_{2}(c)$, various $\mathrm{Tc}$ oxyhalides $(c, 1,8), \mathrm{Tc}_{2} \mathrm{~s}_{7}(c), \mathrm{TcS}_{2}(c), \mathrm{TcO}_{4}^{2-}$ solid salts, and aqueous $\mathrm{Tc}$ (III) and Tc(IV) halide, sulfate, and carbonate complexes. Quality solubility data for $\mathrm{TcO}_{2} \cdot 2 \mathrm{H}_{2} \mathrm{O}(\mathrm{am})$ are required for many applications. Experimental heat capacities for $\mathrm{Tc}(\mathrm{c})$ above $15 \mathrm{~K}$ are also needed. Qualitative information is needed about the nature of the Tc(III) and Tc (IV) phosphate and polyphosphate complexes. Hydrolysis of cationic Tc(V) is also not well understood. Until these data are reported, thermodynamic chemical equilibrium modeling calculations for sone systems cannot be completely trusted. 
The author is grateful to Larry Ramspott who recognized the need for a thorough technetium thermodynamic data review, to Dana Isherwood and Thonas Wolery for their encouragenent and support, and to the U. S. Department of Energy who funded this study under contract

Thanks are especially due to Jack Harrar for numerous discussions of the interpretation of aqueous electrochemical measurements, Donald G. Miller for helping translate French language articles, and Oacar Krikorian for a discussion of Knudsen mess spectrometry. The author is grateful to Sue Frumenti for typing/word processing this manuscript, with the able asaistance of Karen Dengler, Elsie We1la, Sundy Carey, and Theresa Freitas. Bill Shissler's skilled editing of the original manuscript is also appreciated. 
1. C. Perrier and E. Segré, "Some Chemical Properties of Blement 43," J. Chem. Phys. 5, pp. 712-716 (1937).

2. C. Perrier and E. Segré, "Some Chemical Properties of Element 43. II," J. Chem. Phys. I, pp. 155-156 (1939).

3. G. E. Boyd, "Technetium and Promethium," J. Chem. Educ. 36, Pp. 3-14 (1959).

4. E. Anders, "The Radiochenistry of Technetium," Subcomittee on Radiochenistry, N.A.S. - N.R.C. (Office of Technical Services, Dept. of Conerce, Washington, D.C., 1960).

5. R. Colton and R. D. Peacock, "An Outline of Technetium Chemistry," Quarterly Reviews (London) 16, PP. 299-315 (1962).

6. A. K. Lavrukhina and A. A. Pozdnyakov, "Analytical Cheniotry of Technetium, Promethium, Astatine and Francium, "Engliah translation (Ann Arbor-Humphrey Science, Ann Arbor, Michigan, 1970).

7. R. D. Peacock, "Technetium," in Comphrensive Inorganic Chemistry (Pergamon Press, Oxford, Chap. 38, 1973), pp. 877-898.

8. K. Schwochau, "The Present Status of Technetium Chemistry," Radiochimica Acta 32, pp. 139-152 (1983).

9. M. J. Clarke and P. H. Fackler, "The Chemistry of Technetium: Towards Improved Diagnostic Agents," in Structure and Bonding (Springer-Verlag, Berlin, 1982), Vol. 50, pp. 57-78.

10. G. H. Cartledge, "The Mechanism of the Inhibition of Corrosion by the Pertechnetate Ion. I. The Orgin and Nature of Reaction Products," J. Phys. Chem. 59, Pp. 979-984 (1955).

11. K. T. Bainbridge and M. Goldhaber, "Influence of Chemical State on the Lifetime of an Isomer," Phys. Rey. 85, pp. 1260-1261 (1951).

12. M. Nage1, G. Brunner, K. -P. Dosta1, E. Hartmann, D. Hinneburg, H. Kupsch, D. Pabst, and A. Rigo", "On the Chemically Induced Decay Constant Variation of Tc-99m," Z. Naturforsch. 33A, Pp. 1050-1055 (1978).

13. J. C. Slater, "The Effect of Chemical Combination on the Internal Conversion in Tc," Phys. Rev. 85, pp. 1261-1262 (1951).

14. E. Hartmann, R. Der, and M. Nage1, " $\mathrm{X}_{\alpha}-\mathrm{SW}$-Calculation of the Chemically Induced Decay Constant Variation of $\mathrm{Tc}-99 \mathrm{~m}$ in the Tetrahedral 0xy-Complex Ion and the Octahedral Halogen-Complex Ions," Z. Phys. A290, pp. 349-353 (1979).

15. B. Allard, H. Kigatsi, and B. Torstenfelt, "Technetium: Reduction and Sorption in Granitic Bedrock," Radiochem. Radioanaly. Lett. 37, Pp. 223-230 (1979). 
16. J. Paquette, J. A. K. Reid, and E. L. 2. Rosinger, "Review of Technetium Behavior in Relation to Nuclear Waste Disposal," Atomic Energy of Canada Report TR-25. (Whiteshell Huclear Research Establishment, Pinawa, Manitoba, Canada, Nov. 1980).

17. D. A. Palner and R. E. Meyer, "Absorption of Technetium on Selected Inorganic Ion-Exchange Vaterials and on a Rangc of Naturally Occurring Minerals Under Oxic Conditions," J. Inorg. Nuc1. Chem. 43, pp. 2979-2984 (1981).

18. B. S. Jensen, "Migration Phenomenn of Radionuclides into the Geosphere," (Harwood Academic Publishers, London, 1982), PP. A44-A50.

19. B. Toratenfelt, K. Andersson, H. Kipatsi, B. A11ard, and U. Olofeaon, "Diffusion Keasurements in Compacted Bentonite," in Scientific Basis for Nuclear Waste Menarement, B. V. Topp, editor (Elsevier, Hew York, 1982), PP. 295-302.

20. R. J. Magee and T. J. Gardwe11, "Rhenium and Technetium," in Encyclopedia of Electrochenistry of the Elenents (Marcel Dekker, New York, 1974), Vol. II, Chap. II-4.

21. J. Grassi, J. Devynck, and B. Trémillon, "Blectrochemical studies of Technetium at a Mercury Electrode," Anal. Chim. Acta 107, pp. 47-58 (1979).

22. R. Colton, "The Chemistry of Rhenium and Technetium," (Interscience, John Wiley, London, 1965).

23. R. D. Peacock, "The Chemistry of Technetium and Rhenium," (Elsevier, Ansterdam, 1966).

24. J. H. Canterford and R. Colton, "Halides of the Second and Third Row Transition Metals," (Interscience, John Wiley, London, 1968), Chap. 7, pp. 272-321.

25. G. Bandoli, U. Mazzi, and E. Roncari, "Crystal Structures of Technetium Compounds," Coord. Chem. Rev. 44, pp. 191-227 (1982).

26. A. F. Ruzina, "Analytical Chemistry of Technetium," Soviet Radiochemistry (Eng1. trans.) 21, Pp. 151-160 (1979).

27. S. Fried, "The Preparation of Technetium Metal," J. Am. Chem. Soc. 70, p. 442 (1948).

28. S. Fried, A. H. Jaffey, N. F. Ha11, and L. E. Glendenin, "Ha1f-Life of Long-Lived Tc"99," Phys. Rev. 81, pp. 741-747 (1951).

29. W. Trzebiatowsi and J. Rudzinaki, "The Composition and Structure of Technetium Nitride and Technetium Borides," J. Less-Comon Ketals 6, pp. 244-245 (1964).

30. J. D. Eakins and D. G. Humphries, "Preparation of Technetium Metal," J. Inorg. Nucl. Chem. 25, p. 737 (1963). 
31. I. V. Vinogradov, M. I. Konarev, L. L. Zaitseva, and S. V. Shepel'kov, "Thermal Stability of Amonium Hexachlorotechnetate and Hexabrowotechnetate," Russ. J. Inorg. Chen. (Engl. trans.) 21, pp. 70-72 (1976).

32. I. V. Vinogradov, M. I. Konarev, and L. L. Zaitseva, "Theraal Stability of Amonium and Potassium Hexaiodotechnetates, "Ruds. J. Inorg. Chew. (Eng1. trans.) 26, pp. 852-855 (1981).

33. I. V. Vinogradov, M. I. Konarev, and L. L. Zaitseva, "Thernal Stability of Potassium, Rubidiun, and Cesium Hexabrowotechnetates," Ruse. J. Inors. Cher. (Eng1, trane.) 23, Pp. 975-976 (1978).

34. R. E. Voltz and H. L. Holt, "Electrodeposition of Tc99 from Aqueous Solution," J. Electrochem. Soc. 114, pp. 128-131 (1967).

35. G. W. Parker, G. E. Creek, W. J. Martin, G. M. Herbert, and P. M. Lantz, "Determination of the Melting Point of Technetiun Metal," in Oak Ridge National Leboratory Report ORNL-1260, Pp. 29-34 (1952).

36. E. Anderson, R. A. Buckley, A. Hellawell, and $W$. Hume-Rothery, "A Determination of the Melting Point of Element 43 (Technetium)," Nature 188, pp. 48-49 (196n).

37. R. G. Behrens and G. H. Rinehart, "Vapor Pressure and Sublimation Enthalpy of Elemental Technetium," J. Les, 8 -Common Metals 75. Pp. 241-254 (1980).

38. D. R. Stu11 and G. C. Sinke, "Thermodynamic Properties of the Elements," (Advances in Chemistry, Series $\$ 18$, ACS, Washington, D. C., 1956).

39. R. J. Trainor and M. B. Brodsky, "Yeat Capacity of Technetium," Phys. Rev. B 12, pp. 4867-4869 (1975).

40. G. R. Love, C. C. Koch, H. L. Whaley, and Z. R. Mclutt, "Elastic Moduli and Debye Temperature of Polycrystalline Technetium by U1trasonic Velocity Measurements," J. Less-Common Metals 20, pP. 73-75 (1970).

41. R. C. I. Mooney, "Crystal structure of Element 43," Acta Cryst. 1, pp. 161-162 (1948).

42. D. J. Lain, J. B. Darby, Jr., J. W. Downey, and L. J. Norton, "a-Manganese Phases Containing Technetium-99," Nature 192, p. 744 (1961).

43. O. Muller, H. B. White, and R. Roy, "Crystal Chemiatry of Some Technetium Containing Oxides," J. Inorg. Nucl. Chet. 26, pp. 2075-2086 (1964).

44. J. A. C. Marples and C. C. Koch, "A Low Temperature X-Ray Investigation of Technetium and the Tc-Mo A-15 Compound," Phys. Lett. 41A, pp. 307-308 (1972). 
45. V. I. Spiteyn, A. F. Kuzina, A. A. Oblova, M. I. Glinkina, and I. T. Stepovaya, "On the Nechanism of the Electrochemical Reduction of TCO ${ }_{4}^{-}$Ion on Platinum Cathode in Sulfuric Acid Solutions, "J. Radioanal. Chen. 30, Pp. 561-566 (1976).

46. V. I. Spitsyn, E. G. Ponyatovskii, V. E. Antonov, I. T. Belash, and O. A. Balakhovskii, "Phase Transformations in the Tc-H Systen at High Pressure, Proc, Acad. Sei. USSR, Phys. Chem. Sect. (Engl. trans.) 247, PP. 723-725 (1979).

47. R. Asokaneni, K. Iyakutti, and V. Devanathan, "Bandstructure of Tc and the Effect of Correlation," Solid State Cormu. 30, pp. 385-389 (1979).

48. O. H. Krikorian, J. H. Carpenter, and R. S. Newbury, "A Mase Spectrometric study of the Enthalpy of Sublimation of Technetium," Hiph Temp. Sci. 1, pp. 313-330 (1969).

49. D. E. Poland, J. W. Green, and J. L. Margrave, "Ideal Gas Thermodynamic Functions of Some Selected Elements," J. Chem. Eng. Date 7, pp. 389-390 (1962).

50. J. Hieniec, "Struktury Binarnych Stopó Technetu z Niektórymi Metalami Przejóciowymi," Nukleonike 10 (Supplement), pp. 23-29 (1965).

51. 0. Kubaschewski, "Ixon-Binary Phase Diagrams," (Springer-Verlag, Berlin, 1982), Pp. 146-7.

52. V. I. Spitsyn, V. E. Antonov, O. A. Balakhovskii, I. T. Belash, E. G. Ponyatovskii, V. I. Rashchupkin, and V. Sh. Shekhtman, "Structure and Superconductive Properties of the High-Pressure Phase in the Technetium-Hydrogen System," Proc. Acad. Sci. USSR, Phys. Chem. Sect. (Eng1. trans.) 260, pp. 795-798 (1981).

53. R. Colton, J. Dalziel, W. P. Griffith, and G. Wilkinson, "Polarographic Study of Manganese, Technetium, and Rhenium," J. Chem. Soc., Pp. 71-78 (i960).

54. J. G. F1oss and A. V. Grosse, "Technetium Analogues of Rhenohydrides," J. Inorg. Nuc1. Chem. 16, pp. 44-47 (1960).

55. A. P. Ginsberg, "Transition Meta1-Hydrogen Compounds. III. Dipotassium Enneahydridotechnate (VII)," Inorg. Chem. 4, pp. 567-569 (1964).

56. K. J. Franklin, C. J. I. Lock, B. G. Sayer, and G. J. Schrobilgen, "Chemical Applications of ${ }^{99}$ Tc MaR Spectroacopy: Preparation of Novel Tc(VII) Species and their Characterization by Multinuclear NMR Spectroscopy," J. Am. Chem. Soc. 104, Pp. 5303-5306 (1982).

57. H. Basch and A. P. Ginsberg, "A Molecular Orbital Description of TcH'-," J. Phys. Chee. 73, pp. 854-857 (1969). 
58. G. E. Boyd, J. W. Cobble, C. M. Nelson, and W. T. Smith, Jr:, "Chenistry of Technetiun . I. Preparation of Technetiun Heptoxide," J. A. Chen. Soc. 74, pp. 556-557 (1952).

59. W. T. Snith, Jr., J. W. Cobble, and G. B. Boyd, "Thernodynenic Properties of Technetium and Rheniun Compounds. I. Vapor Preseures of Technetiun Beptoxide, Pertechnic Acid and Aqueous Solutions of Pertechnic Acid," J. An. Chen. Soc. 75, Pp. 5773-5776 (1953).

60. C. M. Nelson, G. E. Boyd, and W. T. Smith, Jr., Mkgnetockenistry of Technetium and Rhenium," J. An. Chen. Soc. 76, pp. 34's-352 (1954).

61. H. Selig and S. Fried, "Raman Spectra of Technetiun Heptoxide," Inorg. Muc1. Chen. Lett. 7. Pp. 315-323 (1971).

62. J. W. Cobble, W. T. Sith, Jr., and G. E. Boyd, "Therwodynamic Propertiee of Technetiun and Rhenium Compounds. II. Heats of Formation of Technetiun Heptoxide and Pertechnic Acid, Potential of the Technetiun (IV)-Technetiun (VII) Couple, and a Potential Diagran for Technetiun," J. A. Che. Soc. 75, pp. 5777-5782 (1953).

63. R. H. Gayer, A. Y. Herre11, and R. H. Busey, "The Enthalpiea of Pormation of Technetium Heptaoxide and Pertechnetate Ion," J. Chen. Thermodyn. 8, PP. 959-964 (1976).

64. R. H. Busey, R. B. Bevan, Jr., and R. A. Gilbert, "The Heat Capacity of Potasaium Pertechnetate from 10 to $310 \mathrm{~K}$. Entropy and Gibbs Energy. Entropy of the Aqueous Pertechnetate Ion," J. Chen. Thermodyn. $\dot{4}$, PP. 77-84 (1972).

65. G. Glidewe11, "Bond Energy Terns in Oxides and Oxo-Anions," Inorg. Chim. Acta 24, pp. 149-157 (1977).

66. D. B. Rogers, R. D. Shannon, A. W. Slight, and J. L. Gillson, "Crystal Chemistry of Metal Dioxides with Rutile-Related Structures," Inorg. Chem. 8, pp. 841-849 (1969).

67. I. V. Vinogradov, M. I. Konarev, L. L. Zaitaeva, and S. V. Shepel'kov, "Theranl Stability of Amonium Pertechnetate in Argon and Ammonia," Ruse. J. Inorg. Chem. (Eng1. trans.) 23, pp. 977-978 (1978).

68. T. A. Sasaki and T. Soga, "Blectronic Structure and X-Ray Photoelectron Spectra of Rutile-Family Dioxides Calculated by DV-Xa Cluster Kethod," Phyaica 111B, pp. 304-318 (1981).

69. A. Steffen and R. BHchmann, "Gas Chronatographic Study of Volatile Oxides and Hydroxides of $\mathrm{TC}, \mathrm{Re}, \mathrm{Ru}, \mathrm{O}$ and $\mathrm{Ir}$. I. Inveatigation by Gas Chromatography," Talanta 25, pp. 551-556 (1978).

70. C. Keller and B. Kanellakopulos, "Ternäre Oxide des Drei-Bis Siebenwertigen Technetiums nit Alkalien," J. Inorg. Nuc1 Chen. 27, pp. 787-795 (1965). 
71. C. Keller and M. Wassilopulos, "Ternäre und Quaternäre Oxide des Vier-, Sechs- und Siebenwertigen Technetiums mit Brdalkalien," Radiochivica tcta 5, Pp. 87-91 (1966).

72. J. Hauck, "Zu den Featkörperelektronenspektren Verschiedener Lithium Hexaoxometallate," Z. Maturforschg. 24B, PP. 1349-1351 (1969).

73. M. Lefort, "Oxydo-Reduction du Couple $\mathrm{TcO}_{2}-\mathrm{TcO} \overline{4}$ en Solutions Diluces Sous 1'Effet du Rayonnerent Gama," Buil. Soc. Chin. France, PP. 882-884 (1963).

74. A. Omunwanne, J. Marinoky, and M. Blau, "Charge and Rature of Technetiun species Produced in the Reduction of Pertechnatate by Stannous Ion," J. Hucl. Led. 18, PP. 1099-1105 (1977).

75. B. Goraki and H. Koch, "Zur Chemie des Technetium in Mariger Iösung. I. țber den Zustand des Vierwertigen Technetiun in Wtikriger Lboung," J. Inor. Auc1. Chere. 31, pp. 3565-3571 (1969).

76. E. Sundrehagen, "Polywer Formetion and Hydrolyaation of ${ }^{99} \mathrm{Tc}$ (IV)," Int. J. Appl. Radiat. Isotopes 30, pp. 739-743 (1979).

77. G. H. Cartledge and W. T. Smith, Jr., "Revision of the ElectrodePotential Diagram for Technetium," J. Phys. Chem. 59, pp. 1111-1112 (1955).

78. G. H. Cartledge, "Free Energies of Foration of Hydrous Oxides of Technetium in its Lower Valencies," J. Electrochem. Soc. 118, pp. 231-236 (1971).

79. G. H. Cartledge, "The Electrochenical Behavior of Technetium and Iron Containing Technetium," J. Electrochem. Soc. 118, Pp. 1752-1758 (1971).

80. V. I. Spitsyn, A. F. Kuzina, and S. V. Kryuchkov, "Hydrolysis of the Cluster Anion $\mathrm{Tc}_{2} \mathrm{Cl}_{8} \mathrm{Z}^{-}$in Hydrochloric Acid Solutions," Russ. J. Inorg. Chem. (Engl. trang.) 25, PP. 406-409 (1980).

81. B. J. McDonald and G. J. Tyson, "The Crystal Structurea of Caesium, Amoniun and Potassium Pertechnetates," Acta Cryst. 15, p. 87 (1962).

82. K. Schwochau, "Die Rrista11strucktur von Natriun - und Silberpertechnetat," Z. Naturforschg. 17A, p. 630 (1962).

83. C. Keller and B. Kannellakopulos, "Daratellung und Untersuchung einiger Pertechnetate de Typs $\mathrm{Me}^{\mathrm{I}} \mathrm{TCO}_{4}$," Radiochin. Acte 1 , PP. 107-108 (1963).

84. L. L. Zaitseva, A. V. Velichko, P. N. Petrov and N. T. Chebotarev, "Praseodymiun Pertechnetate and Its Crystalline Hydrates," Russ. J. Inorg. Chew. (Engl. trans.) 17, Pp. 1379-1382 (1972). 
85. L. L. Zaitseva, A. V. Velichko, and H. T. Chebotarev, "Preparation and Physicochemical Propertiea of Neodymiun Pertechnetate," Rusd. J. Inorg. Chem. (Engl. trang.) 17, Pp. 1382-1384 (1972).

86. B. Krebs and R.-D. Hasse, "Refinerents of the Cryotal Structures of $\mathrm{KTCO}_{4}, \mathrm{KReO}_{4}$ and $\mathrm{OsO}_{4}$. The Bond Lengths in Tetrahedral Oxo-Anions and Oxides of $d^{0}$ Transition Metals," Acta Cryst. B32, Pp. 1334-1337 (1976).

87. L. L. Zaiteeva, H. I. Konaruv, A. V. Velichko, and H. M. Korgunova, "Lead (II) Pertechnetate and Per-rhenate," Russ. J. Inorp. Chan. (Engl. trans.) 22, PP. 803-807 (1977).

88. L. L. Zaitseva, H. I. Konarev, A. V. Velichko, and N. V. Morgunova, "Preparation and Physicochemical Properties of Cadmius Pertechnetate and Per-rhenate, "Ruse. J. Inorg. Chem. (Engl. trana.) 23, PP. 978-982 (1978).

89. L. L. Zaitseva, A. V. Velichko, and V. V. Kazakov, "Physicochenical Inveetigation of Magnesiun Pertechnetate and Perrhenate," Ruse. J. Inorg. Ghen (Eng1. trang.) 24, Pp. 1132-1135 (1979).

90. L. L. Zaitseva, A. V. Velichko, A. V. Denin, A. I. Sukhikh, and N. V. Morgunova, "Synthesis and Phyaicochemical Properties of Zinc Pertechnetate and Perrhenate," Russ. J. Inorg. Chen. (Bng1. trans.) 27, pp. 202-205 (1982).

91. L. L. Zaitseva, A. V. Velichko, A. V. Dewin, and A. I. Sukhikh, "Scandium Pertechnetate and Its Crystalline Hydratea," Russ. J. Inorg. Chem (Engl. trans.) 27, pp. 928-931 (1982).

92. G. E. Boyd, "Osmotic and Activity Coefficients of Aqueous $\mathrm{MaTcO}_{4}$ and $\mathrm{NaReO}_{4}$ Solutions at $25^{\circ} \mathrm{C}$," J. Solution Chem. I, pp. 229-238 (1978).

93. K. Schwochau, L. Astheiner, J. Heuck, and H. J. Schenk, "Tetraoxotechnetat (VI) und-Rhenat (VI)," Angew. Chem. 86, pp. 350-35? (1974).

94. L. Astheiver, J. Hauck, H. J. Schenk, and X. Schwochau, "Tetraoxo Anions of Hexavalent Technetium and Rhenium," J. Chea. Phys. 63, Pp. 1988-1991 (1975).

95. L. Aatheiner and K. Schwochau, "Blectrochenical Reduction of $\mathrm{MnO}_{4}^{-}, \mathrm{TcO}_{\overline{4}}^{-}$and $\mathrm{ReO}_{4}^{-}$in Organic Solvents," J. Inorg.

Nuc1. Chere. 38, Pp. 1131-1134 (1976).

96. R. Colton, "Technetium Chlorides," Nhture 193, PP. 872-873 (1962).

97. M. Elder and B. R. Penfold, "The Crystal structure of Technetiun (IV) Chloride. A New $\mathrm{AB}_{4}$ Structure," Inorg. Chen. 5, PP. 1197-1200 (1966).

98. K. Knox, S. Y. Tyree, Jr., R. D. Srivastava, V. Norman, J. Y. Bassett, Jr., and J. H. Hollorray, "Chenistry of Dhenius and Technetiun. I. Synthesis of ReCl $5, \mathrm{TCCl}_{4}$ and Related Compounds," J. An. Chem. Soc. 79, pp. 3358-3361 (1957). 
99. M. Blder and B. R. Penfold, "The Cryatel structure of Technetiun (IV) Chloride," Chen. Conun., PP. 308-309 (1965).

100. L. Brewer, L. A. Bromley, P. W. Gillea, and H. L. Lofgren, "The Thermodynamic Properties of the Halides," in The Chemistry and Metallurgy of Miacellaneous Kateriale, L. L. Quill, editor (Fickraw Hi11, New York, 1950), PP. 76-i92.

101. J. E. Fergusson and J. H. Hickford, "Studies in the Chemietry of Technetium. Complexes of Technetium -(II), - (III), and -(IV) with 1, 2-Bis (Diphenylphosphino)-Ethane," Aust. J. Chee. 23, pp. 453-461 (1970).

102. K. Rinke, M. Klein, and H. Sch"̈fer, "Masenspektronetriache Unterauchungen an Halogeniden des Rheniuma und Technetiua," J. Leas-Cosson Metele 12, Pp. 497-503 (1967).

103. J. Rudolph and K. Btichmann, "it $\_\geq$of Iaothermal Gas Chroastography for the Determination of the Absorption Enthalpies and Entropies of Inorganic Halides at High Temperaturea," J. Chronatography 187, PP. 319-329 (1980).

104. S. Tsalas and K. Brichmann, "Separation of Inorganic Bronides by Adsorption Gas Chronatography," Talanta 27, pp. 201-204 (1980).

105. S. Siegel and D. A. Northrup, "X-Ray Diffraction Studies of Sowe

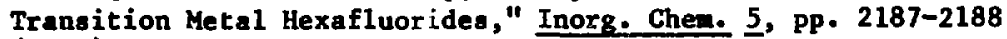
(1966).

106. H. H. Cleassen, G. L. Gc Jdmen, J. H. Holloway, and H. Selig, "Raman Spectra of $\mathrm{MoF}_{6}, \mathrm{TcF}_{6}, \mathrm{eF}_{6}, \mathrm{UF}_{6}, \mathrm{SF}_{6}, \mathrm{SeF}_{6}$, and $\mathrm{TeF}_{6}$ in the Vapor state, "J Chem Phys, 53, Pp. 341-348 (1970).

107. H. Selig and J. G. Malm, "The Vapor-Pressure and Transition Points of $\mathrm{TCCl}_{6}, " \mathrm{~J}$. Inorg. Nucl. Chem. 24, Pp. 641-644 (1962).

108. D. W. Osborne, F. Schreiner, K. Otto, J. G. Malm, and H. Selig, "Heat Capacity, Entropy, and Gibbs Energy of Technetius Hexafluoride Between 2.23 and $350 \mathrm{~K}$; Magnetic Anonaly at $3.12 \mathrm{~K}$; Mean B Energy of ${ }^{9} T \mathrm{TC}, " \mathrm{~J}$. Chen. Phys. 68, PP. 1108-1118 (1973).

109. G. Nagarajan and D. C. Brinkley, "Enthalpy, Free Energy, Entropy, and Heat Capacity of Sone Hexafluorides of Octahedral Symetry," Z. Naturfor:cin. 26A, pP. 1658-1666 (1971).

110. N. A. Koz'min, G. N. Novitskaya, and A. F. Kurina, "Structure of $\mathrm{H} \mathrm{TcCl}{ }^{9 \mathrm{H} \mathrm{O}} \mathrm{O}_{2}$ " J.6Struct. Chem. USSR (Eng1. trans.) 13, p. 878 (1972).

111. P. A. Koz'min and G. N. Novitakaya, "Crystal Structure of Hexachlorotechnetic Acid $\mathrm{H}_{2}\left[\mathrm{TcCl}_{6}\right] \mathrm{9H}_{2} \mathrm{O}$," Koord. Kim. (Eng1. trans.) 1, pp. 376-379 (1975).

112. M. E1der, J. E. Fergusaon, G. J. Gainsford, J. H. Hickford, and B. R. Penfold, "Potassium Pentachlorohydroxytechnetate," J. Che. Soc. (A), pP. 1423-1425 (1967). 
113. X. Schwochau and W. Krasser, "Schwingungsspektren und Rraftkonstanten der Bexahalogeno-Komplexe des Technetiun. (IV) und Rheniu (IV)," 2. Naturforsch. 21A, Pp. 403-407 (1969).

114. I. L. Zaitseva, M. I. Konarev, P. B. Kozhevnikov, I. V. Vinogradov, A. A. Kruglov, ant N. T. Ghebotarev, "Preparation and X-Ray Diffraction Study of Various Hexahalogeno Complexes of $\mathrm{Tc}^{\mathrm{IV}}$ and $\mathrm{Re}^{\mathrm{IV}}, "$ Ruse. J. Inorg. Chem. (Enq1. trans.) 17, PP. 1258-1260 (1972).

115. L. L. Zaiteeva, M. I. Konarev, I. V. Vinogradov, B. G. Kozbinov, A. A. Kruglov, and N. T. Chebotarev, "X-Ray Diffraction Investigation of Tc IV Bexaiodom Conplexes, "Ruse. J. Inors. Ches. (Eng1. trans.) 19, Pp. 531-532 (1974).

116. L. I. Zaitseva, M. I. Konarev, V. S. Il'yashenko, I. V. Vinogradov, S. V. Shepel'kov, A. A. Kruglov, and N. T. Chebotarev,

"Phyaicochemical Properties of Hexabrono-Conplexes of Technetiun (IV);" Ruse. J. Inorg. Cher. (Engl. trans.) 18, pp. 1276-1278 (1973).

117. K. Rösaler and $J$. Winter, "Influence of d-Electron Coufiguration on Phase Transitions in $\mathrm{A}_{2} \mathrm{WX}_{6}$ (Hexahalosetallates IV)," Chem. Phys. Lett. 46, pp. 566-570 (1977).

118. R. C. Elder, G. W. Estes, and E. Deutsch, "Amonium Hexachlorotechnetate (IV)," Acta Cryst. B35, PP, 136-137 (1979).

119. B. Frlec, H. Selig, and H. H. Hyan, "Hydraziniun (+2) Hexafluoronetalates (IV) and - (V) in the $4 \mathrm{~d}$ and $5 \mathrm{~d}$ Transition Series," Inorg. Chem. 6, PP. 1775-1783 (1967).

120. A. F. Kuzina, A. A. Oblova, and V. I. Spitayn, "Technetium (IV) and Technetium (v) Complexes of Bases," Ruse. J. Inorg. Chen. (Bngl. trans.) 17, pp. 1377-1379 (1972).

$\therefore$ : V. V. Zelentaov, N. A. Subbotina, and V. I. Spitsyn, "The Magnetism of the Chloro-Complexes of Technetium," Russ. J. Inorg. Chen. (Engl. trans.) 18, pp. 902-903 (1973).

122. I. V. Vinugradov, L. I. Zaitgeva, M. I. Konarev, and S. V. Shepel'kov, "Solubility of Alkali Hetai and Amonium Hexachlorotechnetates and Hexabrowotechnetates," Russ. J. Inorg. Chon. (Eng1. trans.) 19, pp. 1488-1490 (1974).

123. A. J. Edwarde, D. Hugill, and R. D. Peacock, "New Fluorine Compounda of Technetiun," Hature 200, p. 672 (1963).

124. D. Hugil1 and R. D. Peacock, "Some Quinquevalent Fluorotechnetates," J. Cher. Soc. (A), Pp. 1339-1341 (1966).

125. J. D. Eakine, D. G. Humphreye, end C. E. Kellish, "Nev Compounds in which Technetiun Has a Low Valency," J. Chen. Soc., PP. 6012-6016 (1963). 
126. F. A. Cotten and W. K. Bratton, "A Multiple Bond Between Technecium Atoms in an Octachloroditechnetate Ion," J. Am. Chem. Soc. 87, p. 921 (1965).

127. W. K. Bratton and F. A. Cotton, "Characterization of the Trinegative Octachloroditechnetate Ion;" Inorg. Chem. 9. pp. 789-793 (1970).

128. F. A. Cotton and L. W. Shive, "Structure of Tripotassium Octachloroditechnetate Hydrate," Inorg. Chem. 14, pp. 2032-2035 (1975).

129. F. A. Cotton, A. Davison, V. W. Day, M. F. Fredrich, C. Orvig, and R. Swanson, "Structure of Yttrium Octachloroditechnetate Nonahydrate," Inorg. Chem. 21, pp. 1211-1214 (1982).

130. V. I. Spitsyn, A. F. Kuzina, A. A. Oblova, and L. I. Belyaeva," Formation of a Binuclear Cluster of Technetium with Pyridine," Proc. Acad. Sci. USSR, Phys. Chem. Sect. (Eng1. trans.) 237, pp. 1173-1176 (1977).

131. V. Z. Spitsyn, A. F. Kuzina, A. A. Oblova, S. V. Kryuchkov, and L. I. Belyaeva, "Binuclesr Cluster of Technetium with Quinoline and Some of its Physicochemical Properties," Proc. Acad. Sci. USSR, Phys. Chem. Sect. (Eng1. trans.) 237, pp. 1211-1212 (1977).

132. W. Preetz and G. Peters, "Darstellung und Charakterisierung der Tetrabutylammoniumsalze von $\left[\mathrm{Tc}_{2} \mathrm{Cl}_{8}\right]^{2-},\left[\mathrm{Tc}_{2} \mathrm{Cl}_{8}\right]^{3-}$ und $\left[\mathrm{Tc}_{2} \mathrm{Br}_{8}\right]^{12-}, " \mathrm{Z}$. Natur for $8 \mathrm{ch}$. 35B, pp. 797-80i (1980).

133. F. A. Gotton and B. J. Kalbacher, "Self-Consistent Field Xa Scattered-Wave Treatment of the Electronic Structures of Octachlorodimetalate Anions of Technetium and Tungsten," Inorg. Chen. 16, pp. 2386-2396 (1977).

134. Y. A. Cotton, P. E. Fanwick, L. D. Gage, B. Kalbacher, and D. S. Martin, "Spectroscopic Study of the Tc $2 \mathrm{Cl}_{8}$ - Ion," J. An. Chem. Soc. 99, pp. 5642-5645 (1977).

135. M. Benard, "A Theoretical Study of the Meta1-Metal Interaction in Binuclear Complexes of Transition Groups 6 and 7," J. Am. Chem. Soc. 100, pp. 2354-2362 (1978).

136. P. A, Koz'min and G. N. Novitakaya, "More Precise Detemination of the Structure of $\mathrm{K}_{8}\left[\mathrm{Tc}_{2} \mathrm{Cl}_{8}\right]_{3} \cdot\left(\mathrm{H}_{3} \mathrm{O}\right) \cdot 3 \mathrm{H}_{2} \mathrm{O}$," Koord. Chem. (Engl. trans.) 1, Pp. 201-203 (1975).

137. A. A. Oblova, A. F. Kuzina, L. I. Belyaeva, and Y. I. Spitsyn, "Thernal Stability of Potassium Octachloroditechnetate," Zl. . Neorg. Khile. 27, pp. 2814-2817 (1982).

138. K. Schwochau, K. Hedwig, H. J. Schenk, and 0. Greis, "Identification and Properties of Dinegative Octachloroditechnetate (III)," Inorg. Nuc1. Chen. Lett. 13, Pp. 77-80 (1977). 
139. S. V. Kryuchkov, A. F. Kuzina, and V. I. Spitsyn, "New Technetium Halide Clusters," Dokl. Akad. Nauk. SSSR 266, Pp. 127-130 (1982).

140. P. A. Koz'min, M. D. Surazhskaya, and T. B. Larina, "Atomic

St: witure of an Octameric Technetium Complex with a Complex Syatem of rieta1-Metal Bonds Including Quaternary Tc-Tc Bonds," Proc. Acad. Sci. USSR, Phys. Chen. Sect. (Eng1. trans.) 265, Pp. 656-658 (1982).

141. R. Colton and I. B. Tomkins, "Halides and Oxide Halides of Technetium - I. Technetium (V) Oxide Halides and the Reaction of Thionyl Chloride with Amonium Pertechnetate," Aust. J. Chem. 21, pp. 1981-1985 (1968).

142. J. H. Canterford, R. Colton, and I. B. Tomkins, "Meta1-Oxygen Stretching Frequencies in Heavy Transition Metal Oxide Halides, "Inorg. Nuc1. Chem. Lett. 4, pp. 471-475 (1968).

143. A. Guest, H. E. Howard-Lock, and C. J. L. Lock, "The Vibrational Spectra of Pertechny1 Chloride," J. Mol. Spectro. 43, pp. 273-281 (1972).

144. A. Guest, H. E. Howard-Tock, and C. J. L. Lock, "Dynanical Jahn-Teller Effects in the Near U1traviolet Vapor Phase Absorption Spectra of Perchenyl Chlorwie, $\mathrm{ReO}_{3} \mathrm{Cl}$, and Pertechnyl Chlnride, $\mathrm{TcO}_{3} \mathrm{C1}$," J. Molecular Spectro. 22, pp. 143-157 (1978).

145. A. Mitller, K. H. Schmidt, E. Ahlborn, and C. J. L. Loak, "Schwingungsspektrum und Normalkoordinatenanalyse von $\mathrm{CrO}_{3} \mathrm{Br}-\mathrm{zur}$ Zuordnung der Schwingungsspektren von Molekỉlen und Ionen des Typs $\mathrm{MO}_{3} \mathrm{X}^{\mathrm{M}}-(\mathrm{M}=\mathrm{Cr}, \mathrm{Mn}, \mathrm{Tc}, \operatorname{Re} ; \mathrm{X}=\mathrm{F}, \mathrm{Cl}, \mathrm{Br}, \mathrm{S} ; \mathrm{n}=0,1), "$ Spectrochim. Acta 29A, pp. 1773-1788 (1973).

146. E. J. Baran, "Mittiere Schwingungsamplituden und Thermodynamische Funktionen von IC-3E" " 2 . Phys. Chem. (Leipzig) 257, Pp, 829-831 (1976).

147. C. L. Rr1fs, R. A. Pacer, and R. F. Hirsch, "Technetium Chemistry, Oxidation States and Species," J. Inorg. Nuc1. Chein. 29, pp. 681-691 (1967).

148. A. J. Fidwards, G. R, Jones, and R. J. C. Sills, "The Cryatal Structure of a Trimeric Form of Technecism Oxide Tetrafluoride," Chem. Commun., PP. 1177-1178 (1968).

149. J. Binenboym, U. E1-Gad, and H. Selig, "Reaction of Ammonium Pertechnetate with Anhydrous Hydrogen Fluoride. Vibrational Spectra of Pertechnety1 Fluoride," Inorg. Chen. 13, pp. 319-321 (1974).

150. E. J. Baran, "Vibrational Properties of Pertechnetyl Fluoride:" Spectro. Lett. 8 , pp. 599-603 (1975).

151. H. Selig and J. G. Malm, "The Preparation and Properties of Pertechnety I Fluoride, Tc0 $3 F$," J. Inorg. Mucl. Chem. 25, PP. 349-351 (1963). 
152. R. H. Busey, "Chemistry of Technetium in Hydrochloric Acid Solutions," in Unclassified Document ORNL 2782 (Oak Ridge National Laboratory, 1959), PP. 13-14.

153. F. A. Gotton, A. Davison, V. W. Day, L. D. Gage, and H. S. Trop, "Preparation and Structural Characterization of Salts of Oxotetrachlorotechnetium (V)," Inorg. Chem. 18, PP. 3024-3029 (1979).

154. B. Jeżowska-Trzebiatowska, and M. Baluka, "The Oxychloro Technetate (v)," Bull. Acad. Pol. Sci., Ser. Sci. Chim. 13, Pp. 1-4 (1965).

155. B. Jeżowska-Trzebiatowska, S. Wajda, and M. Baluka, "Structure and Properties of Technetium and Rhenium Compounds of the Type $\left[\mathrm{Me}^{\mathrm{V}_{\mathrm{OX}}}\right]^{2-}, " \mathrm{~J}$. Struct. Chem. USSR (Engl. trans.) 8 , pp. 456-459 (1967).

156. B. Batuka, J. Hanuza, and B. Jeźowaka-Trzebiatowska, "Infrared and Electronic Spectra of the Technetium Oxy-Compounds," Bul1. Acad. Po1. Sci., Ser. Sci. Chim. 20, pp. 271-278 (1972).

157. J. E. Fergusson, A. M. Greenaway, and B. R. Penfold, "Preparative and Structural Studies of Pentahalogeno-0xometallate (V) Salts of the Transition Metals $\mathrm{Cr}$, Mo, $W, \mathrm{Tc}$, Re," Inorg. Chim. Acta 71 , pp. 29-34 (1983).

158. V. I. Spitsyn, M. I. Glinkina and A. F. Kuzina, "Chemistry of Pentavalent Technetium," Proc. Acad. Sci. USSR, Chem. Section (Eng1. trans.) 200, pP. 875-878 (1971).

159. W. Preetz and G. Peters, "Darstellung und Charakterisierung der Tetrabutylamoniumsalze der Tetrahalogenooxotechnate (V), $\left[\mathrm{TcOCl}_{4}\right]^{-}$und $\left[\mathrm{TcOBr}_{4}\right]^{-}, " \mathrm{Z}$. Naturforsch. 35B, PP. 1355-1358 (1980).

160. A. Davison and A. G. Jones, "The Chemistry of Technetium (V)," Int. J. Appl. Radiat. Isot. 33, PP. 875-881 (1982).

161. R. H. Thomas, A. Davison, H. S. Trop, and E. Deutsch, "Technetium Radiopharmaceutical Development. 2. Preparation, Characterization and Synthetic Utility of the Oxotetrahalotechnetate (V) Species Ts0\$4," Inorg. Chem. 19, Pp. 2840-2842 (1980).

162. G. Peters and W. Preetz, "Darstellung und Charakterisierung von Tetrabutyl ammonium-Tetraiodooxotechnetat (V), (TBA) [ TcOI 4 ," . Naturforsch. 36B, PP. 138-140 (1981).

163. J. Ziolkowski, M. Baluka, and B. Ježowska-Trzebiatowska," Synthesis of Technetium (IV) Complexes Using Rhenium (IV) as a Carrier," in Theory and Structure of Complex Compounds, (Symposium, Hroclaw, Poland, 1962), PP. 419-421 (from Chem. Abs. 63, 17460e, 1965).

164. C. L. Rulfs and W. W. Meinke, "Observations on Some Chemical and Physical Properties of Technetium and its Compounds," J. Am. Chem. Soc. 74, PP. 235-236 (1952). 
165. J. E. McDonald and J. W. Cobble, "The Heats of Combustion of ReS and $\operatorname{Re}_{2} \mathrm{~S}_{7}$ and the Thermodynamic Functions for Transition Metal Sulfides," J. Phys. Chem. 66, Pp. 791-794 (1962).

166. I. V. Vinogradov, M. I. Konarev, I. L. Zaitseva, and S. V. Shepel'kov, "Technetium Nitrides," Russ. J. Inorg. Chem. (Engl. trans.) 23, Pp. 639-640 (1978).

167. G. H. Rinehart and R. G. Behrens, 'Mass Spectrometric Determination of the Dissociation Energy of Tcc $(g), "$ J. Phys. Chem. 83, Pp. 2052-2053 (1979).

168. J. W. Cobble, C. M. Nelson, G. W. Parker, W. T. Smith, Jr., and G. E. Boyd, "Chemiotry of Technetium. II. Preparation of Technetium Meta1," J. Am. Chem. Soc. 74, p. 1852 (1952).

169. C. Ferradini, R. Carlier, M. Genet and J. Pucheault, "Effeto Chimiques Associé a l'emission $g^{-}$III. Etude du Techndtium $99 \mathrm{~m}$ Formé par désintegration $B^{-}$de $99 \%$, "Radiochimica Acta 12 , pp. $1-4$ (2969).

170. J. Cifka and P. Vesely, "Some Factors Influencing the Elution of Technetium-99m Generators," Radiochimica Acta 16, Pp. 30-34 (1971).

171. E. Ianovici, P. Lerch, Z. Proso, M. Decombaz, and A. G. Maddock, "Chemical Effects of the Isomeric Transition of $95 \mathrm{~m} \mathrm{Tc}$ in a $\left(\mathrm{NH}_{4}\right)_{2}{ }^{9} \mathrm{TcCl}_{6}$ Matrix," Radiochimica Acta 26, Pp. 141-145 (1979).

172. E. Ianovici, P. Lerch, G. Zahner, and A. G. Maddock, "Chemical Effects of Isomeric Transition of $95 \mathrm{~m}$ Tc in Inorganic Tc (IV)-Complexes," Radiochimica tcta 28, pp. 23-27 (1981).

173. E. Ianovici, P. Lerch, G. Zahner, and A. G. Maddock, "Chemica1 Effects of I.T. ${ }^{95} \mathrm{mc}-{ }^{9} \mathrm{~g}_{\mathrm{Tc}}$ in Some Pertechnetates in Aqueous Solution," Radiochimica Acta 29, pp. 79-82 (1981).

174. M. Jovtschev, H. Koch, and H. Kupsch," Stand und Entwicklungstendenzen auf dem Gebiet der Radiochemie und Chemischen Kerntechnik Chemie Radioaktiver Elemente," Isotopenpraxis 11, Pp. 369-378 (1975).

175. H. A. Friedman, "Iiterature Survey of the Aqueous Chemistry of Technetium Related to Photolysis," Document ORNL/TM-7515, (Oak Ridge National Laboratory, 1981).

176. C. D. Russe11, "Electrochemistry of Technetium," Int. J. App1. Radiat. Isot. 33, pp. 883-889 (1982).

177. C. D. Russe11 and A. G. Gash, "Polarographic Reduction of Pertechnetate," J. Electroanal. Chem. 92, pp. 85-99 (1978).

178. G. E. Boyd, "Osmotic and Activity Coefficients of Aqueous $\mathrm{HTCO}_{4}$ and $\mathrm{HReO}_{4}$ Solutions at $25^{\circ} \mathrm{C}$, "Inorg. Chem. 17, PP. 1808-1810 (1978). 
179. R. H. Busey and 0. I. Keller, Jr., "Structure of the Aqueous Pertechnetate Ion by Raman and Infrared Spectroscopy. Raman and Infrared Spectra of Crystalline $\mathrm{KTcO}_{4}, \mathrm{KReO}_{4}, \mathrm{Ka}_{2} \mathrm{MOO}_{4}$, $\mathrm{Na}_{2} \mathrm{HO}_{4}, \mathrm{Na}_{2} \mathrm{HOO}_{4} \cdot 2 \mathrm{H}_{2} \mathrm{O}$, and $\mathrm{Na}_{2} \mathrm{HO}_{4} \cdot 2 \mathrm{H}_{2} \mathrm{O}, " \mathrm{~J}$. Chem. Phys. 41, Pp. 215-225 (1964).

180. K. Schwochau and L. Astheimer, "Konduktometrische Bestimmung des Diffusions-Koeffizienten von Pertechnetat-Ionen in Wässeriger Lösung," Z. Naturforschg. 17A, p. 820 (1962).

181. V. P. Shvedov and K. V. Kotegov, "Electromigration Method of Determining the Physicochemical Constants of Compounds Existing in a State of Extrene Dilution. II. Determination of a Number of Physicochemical quantities of the Compounds of Tc and Re," Soviet Radiochemistry (Engl. trans.) 5, Pp. 342-345 (1963).

182. G. Kissel and S, W. Feldberg, "Disproportionation of the Technetate Ion in Aqueous Alkaline Nedia. An Electrochemical Study, "J. Phys. Chem. 13, pp. 3082-3088 (1969).

183. C. Bratu, Gh. Bratu, I. Galateanu, and M. Roman, "Study of Lower Valence States of Technetium," J. Radioanal. Chem. 26, pp. 5-16 (1975).

184. B. Pihlar, "Electrochemical Behavior of Technetium (VII) in Acidic Medium," J. Electroanal. Chem. 102, pp. 351-365 (1979).

185. S. V. Krychkov, A. K. Pikaev, A. F. Kuzina, and V. I. Spitsyn, "Electrolytic Dissociation of Technetic Acid in Aqueous Solution by Pulsed Radiolysis," Proc. Acad. Sci. USSR, Phys. Chem. Sect. (Eng1. trans.) 247, pp. 690-692 (1979).

186. R. W. Hurst, "Part I. Carbon and Mercury-Carbon Optically Transparent Electrodes. Part II. Investigation of Redox Properties of Technetium by Cyclic Voltammetry and Thin Layer Spectroelectrochemistry," Ph.D. dissertation (University of Cincinnati, Cincinnati, Ohio, 1980), 198 pp.

187. E. Deutsch, W. R. Heineman, R. Hurst, J. C. Sull ivan, H. A. Mulac, and S. Gordon, "Production, Detection, and Characterization of Transient Hexavalent Technetium in Aqueous Alkaline Media by Pulse Radiolysis and Very Fast Scan Cyclic Voltammetry," J. Chem. Soc. Chem. Comm., pp. 1038-1040 (1978).

188. A. K. Pikaev, S. V. Kryuchkov, A. F. Kuzina, and V. I. Spitsyn, "Pulsed Radiolysis of Neutral Aqueous Solutions of Potassium Pertechnetate," Proc. Acad. Sci. USSR, Phys. Chem. Sect. (Engl. trans.) 236, Pp. 992-995 (1977).

189. C. E. Crouthame1, "Thiocyanate Spectrophotometric Determination of Technetium," Ana1. Chem. 29, pp. 1756-1760 (1957).

1 i. S. K. Majumdar, R. A. Pacer, and C. L. Rulfs, "Rhenium and Technetium (VI) and Meso-(VII) Species," J. Inorg. Mucl. Chem. 31, pp. 33-41 (1969). 
191. S. I. Zhdanov, A. F. Kuzina, and V. I. Spitsyn, "Polarography of Technetium in a Supporting Electrolyte of Sodium Sulphate," Russ. J. Inorg. Chem. (Eng1. trans.) 15, PP. 803-806 (1970).

192. V. I. Spitbyn, A. F. Kuzina, N. N. Zamoshnikova, and A. A. Oblova, in Proceedings 3rd International Conference on Peaceful Use of Atomic Energy, (Genera, 1965); 10, p. 561; cited in reference 174 .

193. P. Rajec, V. Mikulaj, and J. Kadrabova', "Solvent Extraction of Reduced Technetium from Mineral Acid Solutions," J. Radioanal. Chem. 51, pp. 85-95 (1979).

194. E. Deutsch, K. Libson, S. Jurisson, and L. F. Lindoy, "Technetium Chemistry and Technetium Radiopharmaceuticals," in Progress in Inorganic Chemiatry, Vol. 30, S. J. Lippard, editor (Wiley Interscience, New York, 1983), pp. 75-139.

195. H. H. Miller, M. T. Kelley, and P. F. Thomason, "Polarographic Studies of the Reduction of Pertechnetate Ion in Aqueous Solutions," in Advances in Polarography (Pergamon Preas, Symposium Publications Division, New York, 1960), pp. 716-726.

196. I. Astheimer and K. Schwochau, "Zur Polarographie des Technetiums. I. Gleichstrom- und Wechselstrompolarographische Untersuchungen an Pertechnetat-Lösungen," J. Electroanal. Chem. 8, pp. 382-389 (1964).

197. A. F. Kuzina, S. I. Zhdanov, and V. I. Spitsyn, "Polarography of Technetium in Perchlorate Solutions," Proc. Acad. Sci. USSR, Phys. Chem. Sect. (Eng1. trans.) 144, pp. 442-445 (1962).

198. R. Mïnze, "Redox- und hydrolysereaktionen von Rhenium- und Technetiumverbindungen," Z. Phys. Chem. (Leipzig) 238, pp. 364-376 (1968).

199. R. J. Magee, I. A. P. Scots, and C. L. Wilson, "Some Aspects of the Polarographic Behavior of Technetium and Rhenium," Talanta 2, PP. 376-379 (1959).

200. G. B. S. Salaria, C. L. Rulfs, and P. J. Elving, "Polarographic and Coulometric Determination of Technetium," Anal. Chem. 35, pp. 979-982 (1963).

201. V. I. Spitsyn, A. F. Kuzina, S. I. Zhdanov, and I. V. Kaimin, "Polarographic Catalytic Technetium Currents," Russ. J. Inorg. Chem. (Engl. trans.) 15, Pp. 662-664 (1970).

202. R. Miinze, "Reduktion von Rhenium-und Technetiumverbindungen an der Quecksilbertropfelektrode, " Z. Phys. Chem. Bd. 226, pp. 415-419 (1964).

203. G. B. S. Salaria, C. L. Rulfa, and P, J. Elving, "Folarographic Behavior of Technetium," J. Chem. Soc., Pp. 2479-2484 (1963).

204. C. L. Rulfs, R. Pacer, and A. Anderson, "The Polarography of Aqueous Pertechnetate Ion," J. Electroanal. Cher. 15, PP. 61-66 (1967). 
205. G. A. Mazzocchin, F. Kagno, U. Mazzi, and R. Portanova,

"Voltanetric Behavior of Aquecus Technetate (VII) Ion," Inorg. Chim. Acta 9, Pp. 263-268 (1974).

206. J. Paquette, S. J. Lister, and W. E. Lawrence, "Solution Chemistry of Technetium and Iodine," in Proceedings of International Conference on Radioactive Waste Management (Canadian Nuclear Society, Winnipeg, Manitoba, Canada, Sept. 12-15, 1982), PP. 411-414.

207. M. Koyama, Y. Kanchiku, and T. Fujinaga, "Photochemical Behavior of the Hexachlorotechnetate (IV) Ion," Coord. Chem. Rev. 3 , PP. 285-291 (1968).

208. Y. Kanchiku, "Separation and Identification of Chlorocomplexes of Technetium (IV) Formed in Hydrochloric Acid Solutions," Bul1. Soc. Chem. Japan 42, PP. 2831-2835 (1969).

209. J. Y. Guénnec and R. Guillaumont, "Comportement du Tc|IV| a 1 'Echelle des Indicateurs en Milieu non Complexant," Radiochem. Radioanal. Lett. 1, pp. 33-38 (1973).

210. B. No11, S. Seifert, and R. Mtinze, "Zur Hydrolysation von Tech : :ium (IV) in Perchlorsauren Lösungen," Zentralinst. Rernforsch., Rossendorf Dresden (Ber.), Report ZFK-294, Pp. 145-150 (1975).

211. H. C. Helgeson, "Thermodynamics of Hydrothermal Systems at Elevated Temperatures and Pressures," Am. J. Sci. 267, pp. 72.9-804 (1969).

212. G. Akerlöf and H. C. Thomas, "A Study of the Solubility of Strong Electrolytes in Concentrated Solutions," J. Am. Chem. Soc. 56, pp. 593-601 (1934).

213. V. M. Vdovenko, L. N. Lazarev, and Ya. S. Khvorostin, "Thermodynamic Characteristics of the Process of Formation of Complex Compounds of Rutheniur in Aqueous Solutions. II. Investigation of the Interaction of Tetravalent Ruthenium with Sulfate Ions," Soviet Radiochemistry (Engl. trans.) 9, pp. 449-451 (1967).

214. H. E. Wirth, "Activity Coefficients in Sulphuric Acid and Sulphuric-Acid- Sodium-Sulphate Mixtures," Electrochimica Acta 16, pp. 1345-1356 (1971).

215. A. A. Terry and H. E. Zittel, "Determination of Technetium by Controlled- Potential Coulometric Titration in Bufferec Sodium Tripolyphosphate Medium," Anal. Chem. 35, pp. 614-618 (1963).

216. J. Steigman, G. Meinken, and P. Richards, "The Reduction of Pertechnetate-99 by Stannous Chloride-I. The Stoichiometry of the Reaction in HCl, in a Citrate Buffer and in a DTPA Buffer," Int. $J$. App1. Radiat. Isotopes 26, Pp. 601-609 (1975). 
217. R. A. Armstrong and H. Taube, "Chemistry of

trans-Aquonitrosyltetraammine Technetium (I)," Inorg. Chen. 15, pp. 1904-1909 (1976).

218. A. G. Jones and A. Davison, "The Chemistry of Technetium I, II, III, and IV," Int. J. Appl. Radiat. Isotopes 33, pp. 867-874 (1982).

219. D. L. Love and A. E. Greendale, "Polarographic Determination of Technetium and Ruthenium Radionuclides in Fission Products," Ana1. Chen. 32, pp. 780-786 (1960).

220. J. Grassi, P. Rogelet, J. D. Devynck, and B. Trémillon, "Radiopolarography of Technetium (VII) in Acidic Medium," J. Electroanal. Chem. 88, pp. 97-103 (1978).

221. L. Ossicini, F. Saracino, and M. Lederer, "The Solution Chemistry and Chromatographic Behavior of Technetium in Aqueous HC1 and HBr," J. Chromatog. 16, Pp. 524-537 (1964).

222. S. K. Shukla, "Ion Exchange Paper Chromatography of $\mathrm{Tc}(\mathrm{IV}), \mathrm{Tc}(\mathrm{V})$ and Tc(VII) in Hydrochloric Acid," J. Chromatog. 21, Pp. 92-97 (1966).

223. S. K. Shuk1a, "Chromatographic Study of the Reduction of Pertechnetate Ion by and in Hydrochloric Acid," Chromatographia 4, pp. 337-340 (1971).

224. S. K. Shukla, "Chromatographic Study of the Reduction of Pertechnetate Ion by and in Hydrochloric Acid. Part II. The Effect of Bromide and Iodide Ions, and Some Dther Parameters on the Reduction Process." Chromatographia 4, Pp. 341-344 (1971).

225. M. J. Williams and T. Deegan, "The Effect of Concentration Upon the Chromatographic Behavior of Technetium in Concentrated Hydrochloric Acid," J. Chrometog. 54, pp. 123-129 (1971).

226. B. No11 and R. Münze, "Reduction of Pertechnetate in Acid Salt Solution," Zentralinst. Kernforsch., Rossendorf Dresden ZFK-294, pp. 144-145 (1975); Chem. Abs. 86, \#100223u (1977).

227. S. K. Shukla, "Reduction of Pertechnetate-99m Ion by Hydrochloric Acid. I. Preparation of Chromatographically Pure Technetium $-99 \mathrm{~m}$ (IV)," J. Chromatog. 151, pp. $5 i-57$ (1978).

228. J. Cifka, "Lower-0xidation-State 99m Product-Its Determination and Occurrence," Int. J. Appl. Radiat. Isot. 33, pp. 849-855 (1982).

229. J. de Liverant and $W$. Wolf, "Studies on the Reduction of [99m $\mathrm{Tc}$ ] $\mathrm{TCO}_{4}^{-}$by Hydrochlori Acid," Int. J. App1. Radiat. Isot. 33, pp. $857-860$ (1982).

230. P. Rajec and F. Macásek, "Electrochemical Reduction of Tc (V) Chloro- Complexes in Acidic Medium, "J. Inorg. Nucl. Chem. 43, Pp. 1607-1609 (1981). 
231. S. K. Shukla, "Chronstographic Study of the Oxidation of Hexachlorotechnetate (IV) Ion," Chrouatographia 4, pp. 472-474 (1971).

232. K. Schwochau, "Uber Stabilität and Liganden-Austauschgeschwindigkeit der Hexachloro- und Hexabromo-Komplexe des Technetium (IV) and Rhenium (IV), " $\mathbf{Z}$. Naturforschg. 20A, PP. 1286-1289 (1965).

233. T. Fujinaga, M. Royama, and Y. Kanchiku, "Photochemical Reaction of Technetium (IV) Chlorocomplexes," Bul1. Chep. Soc. Japan 40, Pp. 2970-2971 (1967).

234. M. Kawashima, M. Koyama, and T. Fujinaga, "Aquation of Hexahalogenotechnetium (IV)," J. Inorg. Mucl. Chem. 38, pp. 819-822 (1976).

235. E. Ianovici, M. Kosinski, P. Lerch, and A. G. Maddock, "The Aquation of Hexachlorotechnetate (IV)," J. Radioanal. Chem. 64, pp. 315-326 (1981).

236. F. A. Cotton and E. Pedersen, "Magnetic and Electrochemical Properties of Transition Metal Complexes with Multiple Meta1-to-Metal Bonds. I. $\left[\mathrm{Tc}_{2} \mathrm{Cl}_{8}\right]^{\mathrm{n}-}$ and $\left[\mathrm{Re}_{2} \mathrm{Cl}_{8}\right]^{\mathrm{n}-}$ with $\mathrm{n}=2$ and $3, "$ Inorg. Chem. 14, Pp. 383-387 (1975).

237. R. Minze, "Neue Hexahalogenmetallate des Rheniums und Technetiums," Z. Phys. Chem. (Leiprig) 239, pp. 31-32 (1968).

238. R. Minze, "Reduktion von Tc(IV)-Verbindungen an Edelmetallelektroden," Isotopenpraxis 11, pp. 29-30 (1975).

239. H. S. Trop, A. Davison, G. H. Carey, B. V. de Pamphilis, A. G. Jones, and M. A. Davis, "Electrochemical Studies on Halide and Pseudo-Halide Complexes of Technetium and Rhenium," J. Inorg. Nucl. Chem. 41, PP. 271-272 (1979).

240. J. Steigman, G. Meinken, and P. Richarda, "The Reduction of Pertechnetate-99 by Stannous Chloride-II. The Stoichiometry of the Reaction in Aqueous Solutions of Several Phosphorus (V) Compounds," Int. J. App1. Radiat. Isotopes 29, pp. 653-660 (1978). 